\title{
Bioaccumulation assessment of nanomaterials using freshwater invertebrate species
}

Sebastian Kuehr ${ }^{1,2}$, Verena Kosfeld ${ }^{1,3}$ and Christian Schlechtriem ${ }^{1,2,3^{*}}$ (])

\begin{abstract}
Background: The high production volume of engineered nanomaterials (ENMs) may lead to high pressure on the environment, and a scientific assessment of ENMs that bioaccumulate in organisms and biomagnify in the food web is necessary. Within the regulation of chemicals in several jurisdictions, such as the European regulation REACH, the bioconcentration factor is the standard endpoint. The bioconcentration factor is mostly determined by flow-through fish tests. However, nanomaterials tend to agglomerate, which may lead to sedimentation in aquatic environments. The bioavailability of the tested nanomaterials may be thus impaired for pelagic species, including fish, in comparison to benthic or filtrating species. Several risk assessment regulations allow the usage of data gained during tests using invertebrates and such data may allow a waiver of further tests using vertebrates. The aim of this study was to elucidate the potential of different freshwater invertebrate species to be used in laboratory bioaccumulation studies on ENMs and to give some guidance for the use of bioaccumulation endpoints derived from studies using aquatic invertebrate species in the risk assessment process for ENMs.
\end{abstract}

Results: The existing literature related to the testing of nanomaterial bioaccumulation with freshwater invertebrates was screened and reviewed to find suitable test species with regard to their ecology and physiology, as well as laboratory test systems allowing to investigate the bioavailability/bioaccumulation of nanomaterials with the respective species. Bivalvia, gastropoda, isopoda, amphipoda, and branchiopoda were reviewed and their suitability for bioaccumulation testing was assessed. Amphipods and bivalves represent worst-case scenarios and show clear advantages to be used as test organisms. However, only amphipods allow the examination of two clearly independent exposure pathways (water and diet).

Conclusion: Amphipods are suitable test organisms for bioaccumulation testing of ENMs. The results from amphipod bioconcentration and biomagnification tests can be included in a tiered assessment suggested at the end of this study allowing a clear grading of the tested nanomaterials as "bioaccumulative" or "non bioaccumulative." Due to the worst-case scenario of the amphipod test, this approach may allow a waiver of further vertebrate tests.

Keywords: Risk assessment, Nanomaterials, Bioconcentration, Biomagnification, Invertebrates

*Correspondence: christian.schlechtriem@ime.fraunhofer.de 1 Department Bioaccumulation and Animal Metabolism, Fraunhofer Institute for Molecular Biology and Applied Ecology IME, Auf dem Aberg 1, 57392 Schmallenberg, Germany

Full list of author information is available at the end of the article

\section{Background}

The high production volume of engineered nanomaterials (ENMs) may lead to high pressure on the environment and can only be long lasting and sustainable if environmental and human health protection is ensured. The identification and scientific assessment of compounds that bioaccumulate in organisms and biomagnify in the food web are important aspects in the regulation

\section{Springer Open}

(c) The Author(s) 2021. This article is licensed under a Creative Commons Attribution 4.0 International License, which permits use, sharing, adaptation, distribution and reproduction in any medium or format, as long as you give appropriate credit to the original author(s) and the source, provide a link to the Creative Commons licence, and indicate if changes were made. The images or other third party material in this article are included in the article's Creative Commons licence, unless indicated otherwise in a credit line to the material. If material is not included in the article's Creative Commons licence and your intended use is not permitted by statutory regulation or exceeds the permitted use, you will need to obtain permission directly from the copyright holder. To view a copy of this licence, visit http://creativeco mmons.org/licenses/by/4.0/. 
of chemicals in several jurisdictions, such as the European regulation concerning the registration, evaluation, authorisation and restriction of chemicals (REACH), the Turkish law KKDIK (Kaydi, Değerlendirilmesi, İzni, Kisitlanmasi), the High Production Volume Challenge Program of the USA, or the Toxic Chemicals Control Act of Korea [1-4]. The bioconcentration factor (BCF), as commonly determined by the flow-through fish test according to OECD TG 305 [5], is the standard endpoint in regulatory bioaccumulation assessment and describes the ratio between the body burden of a substance $(\mathrm{mg} /$ $\mathrm{kg}$ ) taken up from the surrounding medium (water) and the exposure concentration $(\mathrm{mg} / \mathrm{L})$. The test system is well established and allows the comparison of results of different studies and is thus preferred for instance in the regulatory processes under REACH [1]. However, depending on the properties of the test items, the performance of fish bioconcentration tests can be challenging or may be even not suitable. This is a major concern with respect to the special characteristics of some ENMs [14]. ENMs tend to agglomerate, leading to sedimentation in aquatic environments [6]. Thus, the bioavailability of the tested ENMs may be impaired for pelagic species, including fish, in comparison to benthic or filtrating species. This aspect seems to be of relevance especially at the mostly very high exposure concentrations applied in laboratory studies [6-8]. Furthermore, several studies indicate that the major uptake pathway for NMs of fish is by oral uptake following dietary exposure. However, metal and metal oxide-based NMs ingested by fish in this way showed only limited transfer through the blood system to other organs [9-18]. The bioaccumulation potential of compounds that are ingested via the diet can be expressed as the biomagnification factor (BMF) describing the ratio between the body burden of a substance and the concentration of the substance in the diet. Alternatively, a BAF (bioaccumulation factor) can be calculated which is, however, less specific and corresponds to the body burden of an organism and the concentration in the animal's environment not distinguishing between the different uptake pathways. Hou et al. showed that the logarithmic BCF values of fish were 1-2 orders of magnitudes lower for the same ENM than in Daphnia magna and underlined the lack of suitability of fish as a test organism for regulatory bioaccumulation assessment of ENMs which obviously does not represent a worst-case scenario [19]. Kühnel and Nickel identified the need for the development of an amendment to OECD TG 305 and proposed the use of other species, like crustaceans and bivalves, for bioaccumulation testing [20]. REACH was developed without having regard to the mode of action of nanomaterials and their special behavior, and therefore, the development of other more suitable methods is required [21]. According to Annexes VIII-XIII of the REACH regulation, test methods could be adapted if the actual method induces no significant or an unexpected exposure [22]. Other taxonomic groups than fish are allowed to be used in bioconcentration studies providing endpoints which could be used for assessing a chemicals bioaccumulation potential [1]. The American Society for Testing and Materials (ASTM) mussel bioconcentration test is suggested as an alternative test concept [23]. The results of such studies should be used in combination with further information to investigate if $\mathrm{B}$ (bioaccumulative, under REACH: BCF value $\geq 2000$ ) or $\mathrm{vB}$ (very bioaccumulative, under $\mathrm{REACH}$ : $\mathrm{BCF}$ value $\geq 5000$ ) criteria are fulfilled (e.g., [1]).

In 2007, de Wolf et al. calculated the need of about 326,700 fish for the estimation of bioconcentration factors for nearly 5500 chemical compounds. This is only for $\mathrm{REACH}$ and represents the amount of test animals if just the minimum number of 108 fish per test is used [24]. The usage of invertebrates for bioaccumulation tests would fit to the principles of the 3Rs [25-27] and is in agreement with the European Council Directive 86/609/ EEC [28] that ensures that the animal species with the lowest degree of neurophysiological sensitivity are used for scientific studies. According to the directive, invertebrates do not fall within the given definition of animals as all living vertebrates, without humans [28, 29]. The high number of fish required for testing does not only raise an ethical problem but there is also a need to rethink the test concept with regard to economic reasons. A single test may last up to several weeks leading to high costs for labor, water, feed, and further resources.

Handy et al. [30] proposed a tiered testing strategy for ENMs, including data from invertebrate studies at the second tier. According to the tiered approach, the tested material will only be tested on the next higher tier if the data from the lower tier show a credible risk for bioaccumulation. In this way only the conspicuous materials would go forward to in vivo testing (Tier 4) which is essentially the OECD TG 305 method for dietary bioaccumulation testing using fish. Thus, the data from invertebrate studies may allow a waiver of further tests using vertebrates. Even though the authors suggest the use of terrestrial invertebrate species, such as earthworms or nematodes, for testing the bioaccumulation of ENMs, we would rather suggest the use of aquatic invertebrate species to allow a more adequate prediction of the bioaccumulation potential of ENMs in fish.

The aim of this literature study is to elucidate the potential of different aquatic invertebrate species to be used in laboratory bioaccumulation studies on ENMs. The bioaccumulation of metal and metal oxide ENMs is the focus of this study, but the results may also be 
applied to polymer- and carbon-only-based ENMs showing different characteristics and fate in the environment and aquatic organisms. First, general requirements are defined that must be fulfilled by the species and related test systems to be suitable for the proper bioaccumulation assessment of metal and metal oxide-based ENMs. Second, we give a summary of a broad literature review on selected invertebrate groups and species with regard to their use in bioaccumulation studies. Third, the pros and cons of the different organisms for bioaccumulation testing are discussed. Finally, some guidance for the use of bioaccumulation endpoints derived from studies using aquatic invertebrate species in the risk assessment process for ENMs is provided.

\section{Suitability of aquatic invertebrate species for testing bioaccumulation of ENMs}

Bioaccumulation of ENMs is the result of the dynamic interplay of different factors, including substance-specific physico-chemical properties, the biological and ecological properties of the receiving organism, as well as its habitat characteristics. Therefore, test systems need to fulfill a range of general requirements to be suitable for the assessment of the bioaccumulation of ENMs in aquatic organisms. For the required information a review was conducted using Scopus, Web of Science, and Google scholar. For the search we used the keywords "bivalve," "gastropod," "isopod," "amphipod," "branchiopod," and "daphnia" (and the plural forms) in combination with "nanomaterial," "nanoparticle," and "bioaccumulation," "bioconcentration," "biomagnification," "uptake," and "elimination." Field studies and studies using marine species were excluded (only with the exception for physiological or mechanistic information). In addition, studies using test items with diameters higher than $100 \mathrm{~nm}$ or test items not based on metals or metal oxides were also excluded.

\section{Biology and ecology of test species}

The ecology of an aquatic organism can have a significant impact on the bioavailability and thus the bioaccumulation of ENMs. In this context, the composition of the water is of crucial importance. In marine environments ENMs tend to aggregate and agglomerate on a larger scale than in freshwater, due to physico-chemical processes induced by the surface charges of the ENMs, as well as the decreased electrophoretic mobility and the higher ionic strength of marine water [31]. Thus, the bioavailability of ENMs and potentially released ions is decreased in marine waters with a high ionic load [32]. Furthermore, transformation of ENMs may be enhanced under marine conditions due to the high $\mathrm{Cl}^{-}$content and thus may affect the bioavailability of the particles [33].
Due to the limited bioavailability of ENMs under marine conditions, only the bioaccumulation in fresh water species is considered in this study. Also, the natural habitat (pelagic vs. benthic) of an aquatic organism may affect the bioavailability of ENMs, with sediments being a likely sink for ENMs due to their potential for heteroagglomeration and sedimentation [34], [35]. Key factors affecting the ingestion of ENMs by aquatic organisms mainly relate to the specific way of breathing as well as feed uptake. If the processes of respiration and nutrition are coupled with ENM exposure pathways, an elevated probability of ENM ingestion is likely. Following ingestion of ENMs, it is of particular importance which physicochemical processes take place in the organism, and which may potentially lead to an accumulation of the ENMs or their metals $[36,37]$. In this context, the binding of metals to proteins, like metallothioneins (MT), the binding into intracellular vesicles as granules, or the precipitation in mineral deposits or exoskeletons should be mentioned [38-40]. Furthermore, it should be considered whether there are any processes that may influence the ion regulation and uptake processes. For instance, the uptake of essential metal ions can be increased by specific transporters as is known for $\mathrm{Cu}$ or $\mathrm{Zn}$. For non-essential metals, uptake due to ionic mimicry, as observed for $\mathrm{Ag}^{+}$ or $\mathrm{Cd}^{2+}$ by $\mathrm{Na}^{+}$channels or $\mathrm{Ca}^{2+}$ uptake and transport mechanisms, is possible [41-45]. However, also the cellular uptake of ENMs is possible. For instance, processes of endocytosis/pinocytosis may allow ENMs to enter the cells via the animals surface, as described by Petros and De Simone [46], if this is not impeded by an impermeable cuticula. Testing bioaccumulation of metal and metal oxide-based ENMs under laboratory conditions requires a sound knowledge of the biological and ecological properties of the test organism as well as its natural habitat characteristics.

\section{Culture and breeding of test species}

The test species should be readily available and have an appropriate size to allow the performance of bioaccumulation studies. Animals can be collected in the field and maintained in the laboratory or reproduced and grown under laboratory conditions which are generally preferred to ensure consistency of the test animals. Field sampling requires an uncontaminated collection site which provides a sufficient number of animals of a suitable developmental stage. A method for age and size determination should be available to characterize the collected animals [5]. Culture of test animals in the laboratory requires a sound knowledge of the optimal species-specific breeding and husbandry conditions. Apart from the abiotic factors preferred by the respective species, such as light intensity, temperature, $\mathrm{pH}$, 
and chemical composition of the water, information on the feeding preferences are of elementary importance. Feed items which are commercially available or can be prepared in the lab using standardized preparation procedures as known for algal- or plant-based diets are recommended. Care needs to be taken that the diets ensure a sustainable and sufficient supply of nutrients promoting the growth and development of the animals.

\section{Factors influencing the suitability of aquatic invertebrate species for bioaccumulation testing}

For bioaccumulation testing a homogeneous batch of animals should be used to eliminate any differences of age or size of the animals on the results obtained. To avoid effects attributed to growth during a study performed over a time period of several weeks, adult or slow growing animals are preferred. Generally, reproduction during the test period should be excluded to avoid elimination of accumulated test item through the release of juveniles. This can be achieved by using only test animals of one sex or adjusting test conditions where no reproduction occurs. Only healthy animals showing normal behavior should be selected as test animals. Mortality of animals should be monitored before and during a test to demonstrate optimal test conditions. As for maintenance and breeding of test animals, optimal conditions for the test species should be applied during bioaccumulation testing.

It should be noted that changes in temperature in the experimental system may alter bioaccumulation kinetics of ENMs. Light conditions may allow phototransformation of tested nanomaterials [47-49]. Optimal oxygen concentration in the test medium has to be guaranteed because low oxygen concentrations in water may result in increasing water turnover rates in aquatic organisms. This is in order to satisfy their oxygen needs potentially leading to a faster uptake of contaminants from the water column. However, high oxygen and active aeration of the test system may increase the transformation of ENMs, e.g., by oxidation and potentially dissolution or the release of ions [50-52]. Flow-through conditions are preferred to avoid sedimentation of ENMs in the experimental system [6-8]. However, semi-static conditions are also acceptable as long as constant water concentrations of the test material can be guaranteed.

The feeding requirements of the test organisms during bioaccumulation testing are dependent on the test duration and the test species used. For short-term testing (only hours) it might not be necessary to provide food, but if tests last for several days or even weeks, constant feeding is required. Fasting of test animals may affect the uptake, metabolism, and elimination of a test substance and thus alter its bioaccumulation behavior. The feeding method should be selected carefully especially for bioconcentration testing (exposure via the water), since ENMs might sorb to food and thus lead to dietary intake. This can be avoided by the immediate uptake of food by the test organisms and the continuous removal of feed residues from the test vessels. A further key factor for bioaccumulation testing is the selection of appropriate test concentrations. Test concentrations should be low enough to avoid toxic effects in the test organisms. This should be investigated prior to bioaccumulation testing. Depending on the toxicity of an ENM, the application of low test concentrations may be required which can be challenging regarding the analysis of the test media and the resulting tissue concentrations.

All these aspects need to be taken into account when searching for suitable aquatic invertebrate species for bioaccumulation assessment. In the following, five groups of invertebrate organisms are presented that have been used for bioaccumulation studies, ideally on metals and ENMs. A summary of the related literature is presented in Table 1.

The biology and ecology of the different organisms is described as well as the species-specific key pathways of substance uptake and elimination. Information on the culture and breeding of the different species is provided. Concepts for bioaccumulation testing are summarized if available. Potential endpoints derived from bioaccumulation studies with the different organisms are described and discussed with respect to their potential contribution to the regulatory bioaccumulation assessment of ENMs.

\section{Bivalvia}

\section{Biology and ecology}

The class Bivalvia is part of the phylum Mollusca and includes more than 10,000 species, including animals, like scallops, clams, and mussels. Bivalves can be found in marine and fresh water systems and are benthic organisms that are usually burrowers and therefore have a sedentary existence on the sediment. Bivalves are literally compressed animals and possess a shell composed of two valves that completely enclose their body.

Bivalves have usually very large gills which are used for gas exchange as well as for food collection (Fig. 1). Most bivalves are mainly filter feeders with large water throughputs at high rates [53]. Filter feeding involves trapping particles, like sediment, plankton, and organic debris on the ctenidial filaments, subunits of the ctenidium, the feather-shaped gill-like respiratory organ of many mollusks. The labial palps sort too large particles for immediate removal as pseudofeces or as mucus entrapped particles by periodic contractions of the mantle cavity [54]. Therefore, respiration and nutrition are closely linked in most bivalves since the ctenidia have 
Table 1 References including information on bioaccumulation studies using aquatic invertebrates

\begin{tabular}{|c|c|c|c|c|c|c|c|}
\hline Category & Organism & ENM & $\begin{array}{l}\text { (nominal) } \\
\text { individual size } \\
{[\mathrm{nm}]}\end{array}$ & $\begin{array}{l}\text { Hydrodynamic } \\
\text { diameter [nm] }\end{array}$ & $\begin{array}{l}\text { Exposure } \\
\text { condition }\end{array}$ & Endpoint & References \\
\hline \multirow[t]{12}{*}{ Bivalvia } & A. cygnea & AuNP & 40 & $86 \pm 14$ & Water & $\begin{array}{l}\text { BCF; tissue distri- } \\
\text { bution }\end{array}$ & Moëzzi et al. [421] \\
\hline & C. fluminea & AuNP & 17 & n.d & Diet & $\mathrm{BCF}$ & Renault et al. [109] \\
\hline & C. fluminea & $\mathrm{Al}_{2} \mathrm{O}_{3} \mathrm{NP}$ & 11 & $4-12$ & Sediment/water & $\mathrm{BCF}$ & Stanley et al. [121] \\
\hline & C. fluminea & AuNP & $7.8,15 \& 46$ & n.d & Water & Clearance rate & Hull et al. [122] \\
\hline & C. fluminea & AuNP & 10 & n.d & Water/ diet & $\begin{array}{l}\text { Uptake \& elimi- } \\
\text { nation rates }\end{array}$ & Arini et al. [89] \\
\hline & C. fluminea & $\mathrm{AgNPTiO}_{2} \mathrm{NP}$ & $\begin{array}{l}15 \text { (AgNP) \& } 26 \\
\left(\mathrm{TiO}_{2} \mathrm{NP}\right)\end{array}$ & $\begin{array}{l}27 \text { (AgNP) \& } 351 \\
\left(\mathrm{TiO}_{2} \mathrm{NP}\right)\end{array}$ & Water & $\begin{array}{l}\text { BAF, tissue distri- } \\
\text { bution }\end{array}$ & Kuehr et al. [98] \\
\hline & C. fluminea & CuONP & $12 \pm 8 \& 29.5$ & $140.5 \& 194$ & Water & $\begin{array}{l}\text { Body burden; } \\
\text { tissue distribu- } \\
\text { tion }\end{array}$ & $\begin{array}{l}\text { Koehle-Divo et al. } \\
\text { [422] }\end{array}$ \\
\hline & C. fluminea & $\mathrm{TiO}_{2} \mathrm{NP}$ & $5-10$ & n.d & Sediment & $\begin{array}{l}\text { Body burden; } \\
\text { tissue distribu- } \\
\text { tion }\end{array}$ & Fan et al. [423] \\
\hline & D.polymorpha & $\mathrm{CeO}_{2} \mathrm{NP}$ & 3 & 8 & Water & $\mathrm{BCF}$ & Garaud et al. [303] \\
\hline & D. polymorpha & $\mathrm{CeO}_{2} \mathrm{NP}$ & $3-4$ & 8 & Water & $\begin{array}{l}\text { Body burden; } \\
\text { tissue distribu- } \\
\text { tion }\end{array}$ & Garaud et al. [424] \\
\hline & D. polymorpha & AgNP & $50 \pm 20$ & 80 & Water & $\begin{array}{l}\text { BCF, subcellular } \\
\text { distribution }\end{array}$ & $\begin{array}{l}\text { Zimmermann et al. } \\
\text { [425] }\end{array}$ \\
\hline & D. polymorpha & $\mathrm{TiO}_{2} \mathrm{NP}$ & 10.4 & n.d & Water/ diet & $\mathrm{BCF} / \mathrm{BAF}$ & $\begin{array}{l}\text { Bourgeault et al. } \\
\text { [123] }\end{array}$ \\
\hline \multirow[t]{16}{*}{ Gastropoda } & L. stagnalis & AuNP & 15 & 28 & Diet & Body burden & Hudson et al. [195] \\
\hline & L. stagnalis & CuONP & $7 \pm 1$ & $82 \pm 1$ & Water & Body burden & Misra et al. [426] \\
\hline & L. stagnalis & AgNP & $13 \pm 3 \& 17 \pm 5$ & n.d & Water/diet & $\begin{array}{l}\text { Uptake \& elimi- } \\
\text { nation rates }\end{array}$ & Croteau et al. [187] \\
\hline & L. stagnalis & CUONP & 7 & $77 \pm 5$ & Water/diet & $\begin{array}{l}\text { Uptake \& elimi- } \\
\text { nation rates; } \\
\text { body burden }\end{array}$ & Croteau et al. [427] \\
\hline & L. stagnalis & AgNP & n.d & $36 \pm 1$ & Diet & Uptake rate & Oliver et al. [428] \\
\hline & L. stagnalis & ${ }^{67} \mathrm{ZnONP}$ & $20-70$ & 245 & Diet & Body burden & $\begin{array}{l}\text { Dybowska et al. } \\
\text { [206] }\end{array}$ \\
\hline & L. stagnalis & AgNP & $\begin{array}{r}10.3 \pm 3.4 \& \\
12.8 \pm 4.4\end{array}$ & n.d & Water & Uptake rate & Luoma et al. [429] \\
\hline & P. antipodarum & AgNP & $10-15$ & $\begin{array}{r}12.1 \pm 2.93- \\
13.9 \pm 3.17\end{array}$ & Water/ sediment & Body burden & $\begin{array}{l}\text { Ramskov et al. } \\
\text { [430] }\end{array}$ \\
\hline & P. antipodarum & CuONP & 7 & n.d & Sediment & Body burden & $\begin{array}{l}\text { Ramskov et al. } \\
\text { [176] }\end{array}$ \\
\hline & P. antipodarum & CUONP & $7 \pm 1$ & n.d & Sediment & Body burden & $\begin{array}{l}\text { Ramskov et al. } \\
\text { [431] }\end{array}$ \\
\hline & P. antipodarum & CUONP & 6 & n.d & Sediment & Body burden & Pang et al. [432] \\
\hline & P. antipodarum & CUONP & $6 \& 100$ & $19 \& 204$ & Sediment & Body burden & Pang et al. [433] \\
\hline & B. glabrata & AgNP & $115 \pm 55.6$ & n.d & Water & Body burden & $\begin{array}{l}\text { Oliveira-Filho et al. } \\
\text { [158] }\end{array}$ \\
\hline & B. aeruginosa & AgNP & $\begin{array}{c}18 \pm 7.7 \\
30.2 \pm 9.4 \& \\
57 \pm 19.3\end{array}$ & n.d & Sediment & $\begin{array}{l}\text { BAF, tissue distri- } \\
\text { bution }\end{array}$ & Bao et al. [177] \\
\hline & B. aeruginosa & $\mathrm{TiO}_{2}$ & $11.6 \pm 2.4$ & n.d & Sediment & Body burden & Ma et al. [434] \\
\hline & B. aeruginosa & CUONP & $41.6 \pm 4.6$ & n.d & Sediment & $\begin{array}{l}\text { Body burden; } \\
\text { tissue distribu- } \\
\text { tion }\end{array}$ & Ma et al. [188] \\
\hline Isopoda & A. aquaticus & WCNPS & $<100$ & & Water & Body burden & Ekvall et al. [212] \\
\hline
\end{tabular}


Table 1 (continued)

\begin{tabular}{|c|c|c|c|c|c|c|c|}
\hline Category & Organism & ENM & $\begin{array}{l}\text { (nominal) } \\
\text { individual size } \\
\text { [nm] }\end{array}$ & $\begin{array}{l}\text { Hydrodynamic } \\
\text { diameter }[\mathrm{nm}]\end{array}$ & $\begin{array}{l}\text { Exposure } \\
\text { condition }\end{array}$ & Endpoint & References \\
\hline \multirow[t]{10}{*}{ Amphipoda } & H. azteca & $\mathrm{Al}_{2} \mathrm{O}_{3} \mathrm{NP}$ & 11 & $4-12$ & Sediment/water & Body burden & Stanley et al. [121] \\
\hline & H. azteca & $\mathrm{CuO}$ & $30-40$ & $733.1 \pm 143.4$ & Water & $\mathrm{BCF}$ & Burkal et al. [435] \\
\hline & H. azteca & AgNP & 15 & 27 & Water & Body burden & Kuehr et al. [311] \\
\hline & H. azteca & AuNP & 15 & 28 & Diet & Body burden & Hudson et al. [195] \\
\hline & H. azteca & ZnONP & $22.4 \pm 2.8$ & n.d & Water & Body burden & Poynton et al. [312] \\
\hline & H. azteca & AgNP & 15 & 27 & Water \& diet & Body burden & Kuehr et al. [314] \\
\hline & H. azteca & $\begin{array}{l}\text { AgNP, AuNP, } \\
\mathrm{TiO}_{2} \mathrm{NP}\end{array}$ & $\begin{array}{l}15 \text { (AgNP), } 26 \\
\left(\mathrm{TiO}_{2} \mathrm{NP}\right) \& 60 \\
\text { (AuNP) }\end{array}$ & $\begin{array}{l}51.2 \text { (AgNP), 1,861 } \\
\left(\mathrm{TiO}_{2} \mathrm{NP}\right) \& 61 \\
\text { (AuNP) }\end{array}$ & Water/ diet & $\mathrm{BCF} / \mathrm{BMF}$ & Kuehr et al. [315] \\
\hline & G. fossarum & AgNP & $20,23 \& 27$ & $\begin{array}{l}96 \pm 8.4,56 \pm 3.2 \& \\
\quad 63 \pm 3.2\end{array}$ & Water & $\mathrm{BCF}$ & $\begin{array}{l}\text { Mehennaoui et al. } \\
\text { [270] }\end{array}$ \\
\hline & G. fossarum & AgNP, AuNP & $\begin{array}{l}20,40 \& 80 \\
\quad(\text { AgNP); } 20,40 \\
\& 80 \text { (AuNP) }\end{array}$ & $\begin{array}{l}22 \pm 0.7-78 \pm 2.9 \\
(\text { AgNP) \& } \\
39 \pm 1.5-89 \pm 0.9 \\
\text { (AuNP) }\end{array}$ & Water & Body burden & $\begin{array}{l}\text { Mehennaoui et al. } \\
\text { [304] }\end{array}$ \\
\hline & G. roeseli & $\mathrm{CeO}_{2} \mathrm{NP}$ & 3 & 8 & Water & $B C F$ & Garaud et al. [303] \\
\hline \multirow[t]{19}{*}{ Branchiopoda } & D. magna & AuNP & 20 & n.d & Water & Distribution & Lovern et al. [407] \\
\hline & D. magna & CUONP & $\begin{array}{l}26 \pm 8,45 \pm 11 \& \\
\quad 75 \pm 19\end{array}$ & $\begin{array}{l}263 \pm 38,153 \pm 45 \\
\& 241 \pm 3\end{array}$ & Water & $\begin{array}{l}\text { Spatial distribu- } \\
\text { tion \& burden }\end{array}$ & $\begin{array}{l}\text { Santos-Rasera et al. } \\
\text { [436] }\end{array}$ \\
\hline & D. magna & AgNP & $10-11$ & $22 \& 28.3$ & Diet & Body burden & Kalman et al. [437] \\
\hline & D. magna & AuNP & 10 & $33 \pm 17.3$ & Water \& diet & Body burden & Lee et al. [403] \\
\hline & D. magna & CUONP & $<50$ & $926 \pm 35$ & Water \& diet & Body burden & Wu et al. [376] \\
\hline & D. magna & AgNP & 20 & $40-50$ & Water & Body burden & $\begin{array}{l}\text { Zhao and Wang } \\
\text { [438] }\end{array}$ \\
\hline & D. magna & AuNP & $19 \pm 2.5$ & $24.2 \pm 0.2$ & Water & Elimination rate & Khan et al. [414] \\
\hline & D. magna & ${ }^{65} \mathrm{ZnONP}$ & $10-30$ & $46-56$ & Water & $\begin{array}{l}\text { Uptake \& elimi- } \\
\text { nation rates }\end{array}$ & Li \& Wang [391] \\
\hline & D. magna & $\mathrm{CdSe} / \mathrm{ZnS} Q \mathrm{QDs}^{*}$ & $5.2 \pm 0.4$ & n.d & Water & Body burden & Lewinski et al. [393] \\
\hline & D. magna & $\mathrm{TiO}_{2} \mathrm{NP}$ & 21 & 580.5 & Water & BCF & Zhu et al. [412] \\
\hline & D. magna & ZnONP & $30 \pm 17$ & $\begin{array}{c}111.8 \pm 24.9- \\
670.2 \pm 230\end{array}$ & Water & Body burden & $\begin{array}{l}\text { Skjolding et al. } \\
\text { [386] }\end{array}$ \\
\hline & D. magna & AuNP & $14 \pm 4$ & $225 \pm 61$ & Water & $\begin{array}{l}\text { Uptake \& tissue } \\
\text { distribution }\end{array}$ & Jensen et al. [406] \\
\hline & D. magna & AgNP & $15.5 \pm 3.6$ & $50 \pm 0.7$ & Water & Body burden & Kim et al. [409] \\
\hline & D. magna & AuNP & $10 \& 30$ & $\begin{array}{r}14 \pm 4-142 \pm 53 \& \\
23 \pm 5-225 \pm 61\end{array}$ & Water & $\begin{array}{l}\text { Uptake \& elimi- } \\
\text { nation rates }\end{array}$ & $\begin{array}{l}\text { Skjolding et al. } \\
\text { [387] }\end{array}$ \\
\hline & D. magna & $\mathrm{TiO}_{2} \mathrm{NP}$ & $<25$ & $\begin{array}{c}20.9 \pm 2.89- \\
218 \pm 47.3\end{array}$ & Water & Body burden & Tan \& Wang [392] \\
\hline & D. magna & $\mathrm{TiO}_{2} \mathrm{NP}$ & $30-80$ & n.d & Water & $\mathrm{BCF}$ & Fan et al. [394] \\
\hline & D. magna & AuNP & 10 & $33 \pm 17.3$ & Diet & Body burden & Lee et al. [403] \\
\hline & D. magna & $\mathrm{TiO}_{2} \mathrm{NP}$ & $\begin{array}{l}4.6 \pm 2.6 \\
11.2 \pm 2.9 \\
20.3 \pm 4.3 \\
27.4 \pm 5.2 \& \\
103 \pm 24.6\end{array}$ & $\begin{array}{l}929 \pm 62,908 \pm 3 \\
953 \pm 50 \\
908 \pm 591 \& \\
763 \pm 12\end{array}$ & Water & $\mathrm{BCF} / \mathrm{BMF}$ & Chen et al. [389] \\
\hline & D. magna & $\mathrm{CdSe} / \mathrm{ZnS} \mathrm{QDs}^{*}$ & $\begin{array}{c}4.5 \pm 0.5- \\
4.9 \pm 0.7\end{array}$ & n.d & Water & $\begin{array}{l}\text { Uptake \& elimi- } \\
\text { nation rates }\end{array}$ & Lee et al. [405] \\
\hline
\end{tabular}


Table 1 (continued)

\begin{tabular}{|c|c|c|c|c|c|c|c|}
\hline Category & Organism & ENM & $\begin{array}{l}\text { (nominal) } \\
\text { individual size } \\
{[\mathrm{nm}]}\end{array}$ & $\begin{array}{l}\text { Hydrodynamic } \\
\text { diameter [nm] }\end{array}$ & $\begin{array}{l}\text { Exposure } \\
\text { condition }\end{array}$ & Endpoint & References \\
\hline & D. magna & AgNP, AuNP, PtNP & $\begin{array}{l}5 \& 50(\mathrm{Ag}), 5 \& \\
50(\mathrm{Au}) \& 56 \\
50(\mathrm{Pt})\end{array}$ & n.d & Water & Body burden & Krystek et al. [411] \\
\hline & D. magna & CuNP, ZnONP & $\begin{array}{l}50 \text { (CuNP) \& } 43 \\
\quad(\text { ZnONP) }\end{array}$ & $\begin{array}{l}568 \pm 72 \text { (CuNP) } \\
\& 1154 \pm 252 \\
\text { (ZnONP) }\end{array}$ & Water & Body burden & Xiao et al. [408] \\
\hline & C. dubia & $\mathrm{TiO}_{2} \mathrm{NP}$ & $<25$ & n.d & Water \& diet & $\mathrm{BAF} / \mathrm{BMF}$ & Dalai et al. [413] \\
\hline & D. magna & AgNP & $3-8$ & 80 & Water \& diet & $\mathrm{BCF} / \mathrm{BMF}$ & Ribeiro et al. [410] \\
\hline
\end{tabular}

become specialized for filter feeding. Some bivalve species are able to perform pedal feeding, a pinocytosis mechanism for the uptake of small particles or singlecell algae or microbes by the surface of their pedal/foot [55-57].

Filter-feeding mussels show a significant impact on the ecosystem they live in [58]. They incorporate huge amounts of suspended organic matter from the water phase into mucus that is released as undigested pseudofeces causing a strong shift of nutrients and changes in the structure of the sediment [56,59-61]. Several benthic amphipods feed on the protein- and carbon-rich pseudofeces of the mussels which thus have an impact on the abundance of several benthic species, also by the transfer of toxins by pelagic-benthic coupling [61-73].

Bivalvia species have been shown to accumulate a wide range of environmental pollutants [74, 75]. Due to their sedentary lifestyle, high filtration rates [76-78], and their ability to accumulate high amounts of heavy metals, bivalves have been used as bioindicators for metal pollution in aquatic systems [79-81]. Accumulation of metals is mainly based on the production of high amounts of metal-binding proteins, like metallothioneins, produced by bivalves as a detoxification mechanism. The characteristics described make bivalves a preferred group of species to investigate accumulation of metal and metal oxide ENMs in aquatic systems [82-86].

\section{Culture and breeding}

Two strategies are available to obtain animals for bioaccumulation testing:

\section{Field collection}

Bivalves used in former studies mostly originated from wild populations, as suggested in the ASTM guideline, [77, 87-89, 98]. It is known that organisms collected in the field might be contaminated with pollutants as it was shown for lindane [76]. Thus, although bivalves are preferably collected from non-polluted areas, animals should be acclimatized in the laboratory for a sufficient time to ensure the elimination of previously ingested contaminants present in the gut content or tissues. In addition, the animals need to acclimate to the new water conditions (ionic strength, $\mathrm{pH}$, etc.) that may alter the filtration activity and thus the uptake kinetic during the exposure. Acclimation periods applied in former studies ranged from one to several weeks $[88,98]$ and up to 5 months [77]. Another problem of field-collected animals could be the infestation with parasites that may impact the performance of the test animals and thus the uptake of test items during bioaccumulation studies [90-94]. Therefore, bivalves should be checked carefully during acclimation to ensure that only healthy animals without any visible abnormalities are used as test animals. Husbandry of collected bivalves under laboratory conditions is possible over longer periods [95]. In general, sufficient food to support survival and growth should be provided. Living or freeze-dried algae, or plant powders, e.g., of stinging nettle leaves, are added to the holding water to provide sufficient nutrients for the filter-feeding animals allowing them to be kept alive for several months under laboratory conditions [96-98]. The laboratory conditions may vary depending on the species. Usage of filtered and or only aerated tap water is possible. Temperatures of $12{ }^{\circ} \mathrm{C} \pm 4{ }^{\circ} \mathrm{C}$ up to $20{ }^{\circ} \mathrm{C} \pm 2{ }^{\circ} \mathrm{C}$ and light for $16 \mathrm{~h}$ per day have been applied [77, 87, 96, 98].

2. Lab culture

Even though the husbandry of the animals is possible, breeding of bivalves under laboratory conditions is highly challenging [99]. The mostly hermaphroditic individuals produce fertilized eggs [100] which evolve to glochidiums, parasitic larvae, that are released into the water. After that they must be ingested by fish (host) and implanted in their gills or need to be attached to the body surface of other vertebrates. 


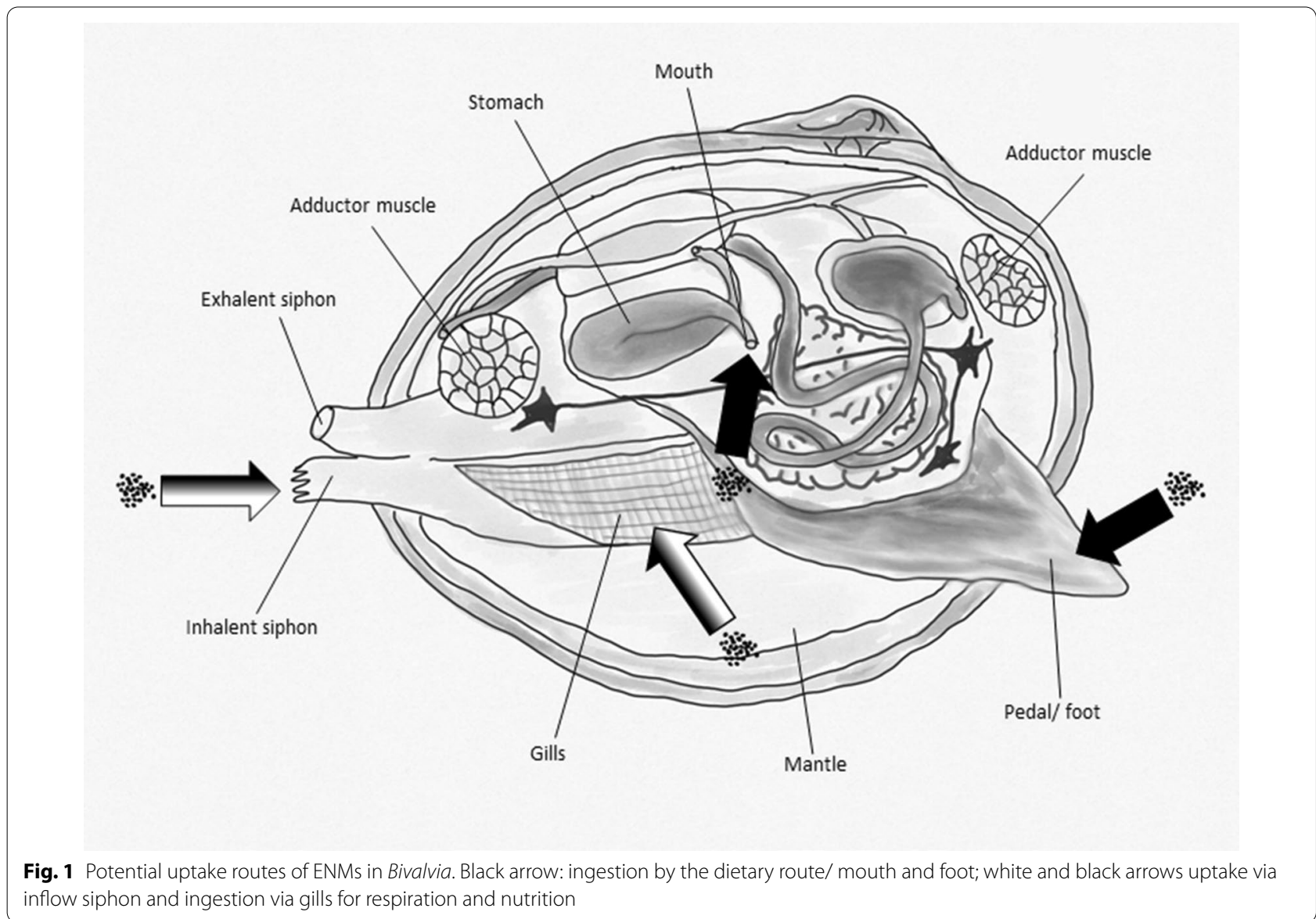

After some time (depending on the species) the juveniles detach from their host and mostly burrow for several years into the substrate of the water system [101, 102]. Juvenile bivalves mostly show a very high mortality, and it may take several years to get mature bivalves that show a sufficient body size to be used in bioaccumulation studies. Thus, the breeding of test organisms is not considered feasible for bivalves.

\section{Bioaccumulation testing}

There are existing standardized test methods that are developed and optimized to investigate the bioaccumulation potential of soluble, non-particulate substances using marine bivalves under flow-through conditions [23]. The proposed species are the oyster (Crassostrea gigas) or the blue mussel (Mytilus edulis). Bivalves have already been used as test organisms to investigate the uptake, accumulation, and elimination of metals. Winter [103] carried out bioaccumulation studies with Dreissena polymorpha, Corbicula fluviatilis, and Anadonta anatina and showed that all of them accumulate dissolved
Cd, whereby the estimated BCF was 19,000 for Dreissena polymorpha and decreased in the order as listed above. The accumulation of $\mathrm{Cd}$ in combination with $\mathrm{Zn}$ was also observed in Mytilus edulis [104]. Mytilus is able to accumulate a wide range of metals, $[105,106]$, proving the high bioavailability of metals for bivalves. M. galloprovincialis was also used by Montes et al. to investigate the bioaccumulation of nanoparticles (NPs). It was shown that insoluble $\mathrm{CeO}_{2}$-NPs were primarily located in the pseudofeces and only a small part was accumulated in the tissue [107]. However, the soluble ZnO-NPs caused an accumulation of $\mathrm{Zn}$ (ions) in the tissue. Comparable results were published by Gomes et al. [108] comparing the accumulation of $\mathrm{Cu}$ from $\mathrm{CuO}-\mathrm{NPs}$ and dissolved $\mathrm{Cu}^{2+}$. In their studies they observed that the digestive gland is the main target of $\mathrm{Cu}$ accumulation and that the $\mathrm{Cu}$ accumulation from free $\mathrm{Cu}^{2+}$ is higher than that from $\mathrm{CuO}-\mathrm{NPs}$. For the metal uptake in bivalves, there are two pathways to be considered. Renault et al. [109] estimated tissue-specific BCFs (equivalent to BAF as described above) for $\mathrm{Au}$ of 4000 in gills and 26,000 in the visceral mass of Corbicula fluminea after dietary exposure with 
algae loaded with Au-NPs. The accumulation of Au-NPs in Scrobicularia plana was investigated by Jin-Fen Pan [110]. Ferry et al. [11] mentioned that bivalves represent as filter feeders one of the most important pathways of nanomaterials into the human food chain. The bivalve species used for bioaccumulation testing were selected on the basis of availability, as well as their commercial, recreational and ecological importance, and the previous successful use and ease of handling in the laboratory. Corbicula spec. is often used as a brackish species that is also widely spread in fresh water systems in Africa, North and South America, Europe, and the Pacific Islands [111-116]. Apart from Corbicula, Dreissena is one of the most aggressive and successful freshwater invaders and thus also widely spread throughout Europe and North America $[117,118]$. The invasive species with euryoecious characteristics show a very high filtration rate and a rapid growth that makes these species a potential test organism for bioaccumulation studies with ENMs [119, 120]. The freshwater species used for bioaccumulation tests with ENMs were C. fluminea [89, 98, 109, 121, 122] or D. polymorpha [123]. The size of the used animals was between 20 and $30 \mathrm{~mm}$ [98, 123]. A standardized test system for the assessment of the bioaccumulation potential of ENMs in bivalves was recently described by Kuehr et al. [98].

Mussels show a relationship between the size of the animals and the potential for bioaccumulation due to the higher filtration rate of juvenile mussels. Thus, smaller individuals accumulate significantly more organic test substance than larger ones, while older individuals display a longer terminal half-life than younger ones. Low temperatures slow down the filtration process, inhibit growth, and may expand the life expectancy of zebra mussel $[124,125]$. Increasing temperature and the presence of higher particulate matter (food) also increase the uptake by increased filtration rates [126-128]. Thus, the feeding during the studies may alter the uptake rate of the animals leading to different BAF values. However, as observed by Kuehr et al. [98] the filtration behavior was minimized or nearly stopped when no feeding occurred during the test. The filtration rate can also be impacted by the exposure concentration. Bivalves show a well described protecting mechanism of valve closing and decreased filtration activity to avoid toxic effects caused by the surrounding medium [74, 98, 128-134]. Thus, preliminary tests should be carried out to determine exposure concentrations which do not affect the valve closing behavior or filtration rate. Other conditions, like light and oxygen levels and $\mathrm{pH}$, were monitored during the given studies, but no effects on the animals were described.

The duration of uptake phases described in the literature ranges from one hour up to several days and depuration phases were applied lasting 3 up to 6 days under semi-static [123] or flow-through conditions [98]. In a recent study, C. fluminea was exposed in a zuger glass system which allowed constant exposure conditions for up to 170 animals at flow rated of $4 \mathrm{~L} / \mathrm{h}$. A further and more detailed description of the test system can be found in Kuehr et al. [98].

Bivalve samples collected during bioaccumulation studies mostly consist of the soft body dissected from 3 to 4 individuals depending on size and species. It is recommended that sampled animals are replaced by new ones, separated by a grid, to maintain the filtration capacity of the biomass in the exposure system [88].

Soft parts of bivalves have been mostly dissected for measurement of tissue concentrations [77, 78, 98, 135] allowing to draw conclusions on the bioavailability, incorporation, transport, and fate of ENMs or their released ions. The physiological and morphological structure of the mussel tissue also allows the enzymatic digestion as part of the tissue preparation process without dissolution of previously ingested or accumulated ENMs making the analysis of particles using methods, like single particle inductively coupled plasma mass spectrometry possible (spICP-MS) [98, 136, 137].

However, due to the filtration behavior for feeding and breathing and the resulting uptake mechanisms, only BAF values can be calculated based on the results of bioaccumulation studies using bivalves as test organism.

\section{Gastropoda \\ Biology and ecology}

With 30,000 described species the class Gastropoda is the largest class of molluscs. Gastropods are the only group of molluscs that have also successfully colonized terrestrial habitats. Gastropods play an important role in the decomposition of organic material in aquatic systems and serve as a food source for organisms of higher trophic levels, like leeches, crayfish, fish, and bugs [138-142]. By this, gastropods may contribute to trophic transfer and secondary poisoning by ingestion and bioaccumulation of ENMs.

Only few gastropods are filter feeders which are able to ingest suspended ENMs. Most gastropoda feed on a wide range of foods, containing algae, detritus, plankton, sponges, polychaets, a variety of cnidarians, crustaceans, other mollusks, fish, and body fluids. As grazing herbivores (or detrivores), gastropods have significant impact on the density of macrophytes in the ecosystem [143148]. Feeding mostly involves rasping by the radular teeth on the food substratum followed by transfer of the dislodged particles to the mouth (Fig. 2). Salivary glands, the esophagus, and the intestine produce enzymes supporting the extracellular digestion of ingested feed particles 
which takes place in the stomach. The digestive gland is the principal site for intracellular digestion. With regard to the ingestion of ENMs, dietary uptake or absorption through the permeable membrane (at least for very small ENMs or released metal ions) is of concern [149-151]. However, uptake by respiratory mechanisms may be less important or even non-existent.

Freshwater gastropods can be gill-breathing caenogastropods, like Viviparus viviparus, Bithynia tentaculata, or Potamopyrgus antipodarum with often only one ctenidium or gill. However, most freshwater gastropods are lung-breathing pulmonates, like Lymnaea stagnalis or Biomphalaria glabrata [151, 152]. The pulmonate freshwater snails are air-breathing animals without gills. For filling their mantle cavity or "lungs," they spend time at the water surface [153]. Differences in those residence times of snails on the surface may introduce variability of bioconcentration processes also under experimental conditions [154]. Different respiration modes were identified by Meredith-Williams et al. [155] as the main reason for species-specific differences in the uptake of dissolved contaminants, such as the pharmaceutical carvedilol with the pulmonate snail Planorbarius corneus showing a lower body burden compared to the gill-breathing amphipod Gammarus pulex.

Oliveira-Filho et al. [158] examined the soft tissue of B. glabrata, previously exposed to Ag-NP for four weeks, and measured high tissue concentrations of Ag but without observing any indications of toxicity [156-158]. This was explained with the presence of metal(ion)-binding proteins, like MT, causing detoxification of potentially incorporated metal ions [159]. The presence of these proteins, their gene expression, and activity has been described for a wide range of gastropods [160-169]. Goncalves et al. [170] described a further detoxification strategy for metals by $L$. stagnalis based on phytochelates. These are chelating peptides which detoxify several metal ions [170]. In addition to that, Desouky et al. [171] observed lysosomal granules formed by sequestration of metals with $\mathrm{P}$ and $\mathrm{S}$, leading to an immobilization of free metal ions and thus allowing the detoxification and excretion of the respective metal by defecation or exocytosis. This mechanism allows exposure of gastropods to metal or metal oxide ENMs without increasing the risk of toxic effects. The resulting body burden may be transferred to higher trophic levels or cause secondary poisoning.

\section{Culture and breeding}

The combination of their lifestyle, feeding behavior, accumulation capacity for metals, and their ecological role make gastropods an interesting group of species to be considered in bioaccumulation testing of ENMs. One of the most commonly used gastropods for bioaccumulation studies is the pulmonate gastropod L. stagnalis which is abundant in European freshwaters in which they are widely distributed $[172,173]$.

Two strategies are available to obtain animals for bioaccumulation testing:

\section{Field collection}

Freshwater snails, such as Lymnaea spec., Physa spec., Potomopyrgus spec., or Bellamya spec., have often been collected from ditches [174, 175], but animals can also be obtained from specialized suppliers [174-177]. Collected animals should be acclimatized to laboratory conditions before being used in experiments and it should be controlled that no parasites impair the animals. Several larvae and trematode worms use gastropods as host and may alter their growth and egg production. Parasites may also have an impact on the metabolism, respiration, and feeding behavior of the animals potentially influencing bioaccumulation processes [178-184]. In previous studies acclimation periods of 2 up to 6 weeks turned out to be sufficient to ensure adaptation of the animals to laboratory conditions $[176,177,185-$ 187]. Husbandry of field-collected animals has been mostly carried out under semi-static conditions with temperatures between $17{ }^{\circ} \mathrm{C}, 20{ }^{\circ} \mathrm{C}$ and $24 \pm 1{ }^{\circ} \mathrm{C}$ for P. antipodarum, L. stagnalis or B. glabrata and B. aeruginea, respectively. Light:dark cycles of 12:12 or $16: 8 \mathrm{~h}$ are suitable $[158,176,188,189]$. For feeding (ground) commercial fish food, lettuce leaves and dried spinach can be used and should be added once per week to the culture vessel $[154,157,158$, 176, 177]. Goncalves et al. [157] mentioned that an oxygen content in the water for the culture of Physa acuta should be above $8 \mathrm{mg} / \mathrm{L}$ and a continuous aeration is thus recommended. The culture media should have a $\mathrm{pH}$ value above 7.9 [157]. A standard snail medium with reconstituted water for snail husbandry and laboratory testing was described by Thomas et al. [178], in other studies moderately hard water according to USEPA was used for the culture $[178,190]$.

2. Lab culture

Van Duivenboden et al. [189], explained that under laboratory conditions animals show first sexual activity after seven or 8 weeks. Egg production usually follows two or three weeks after first observed sexual activity. Per day, up to 68 eggs per snail can be produced [189].

Most pulmonates, like the species of the genera Lymnaea and Physa, are monoecious and show high reproduction rates. However, the mortality rate is 


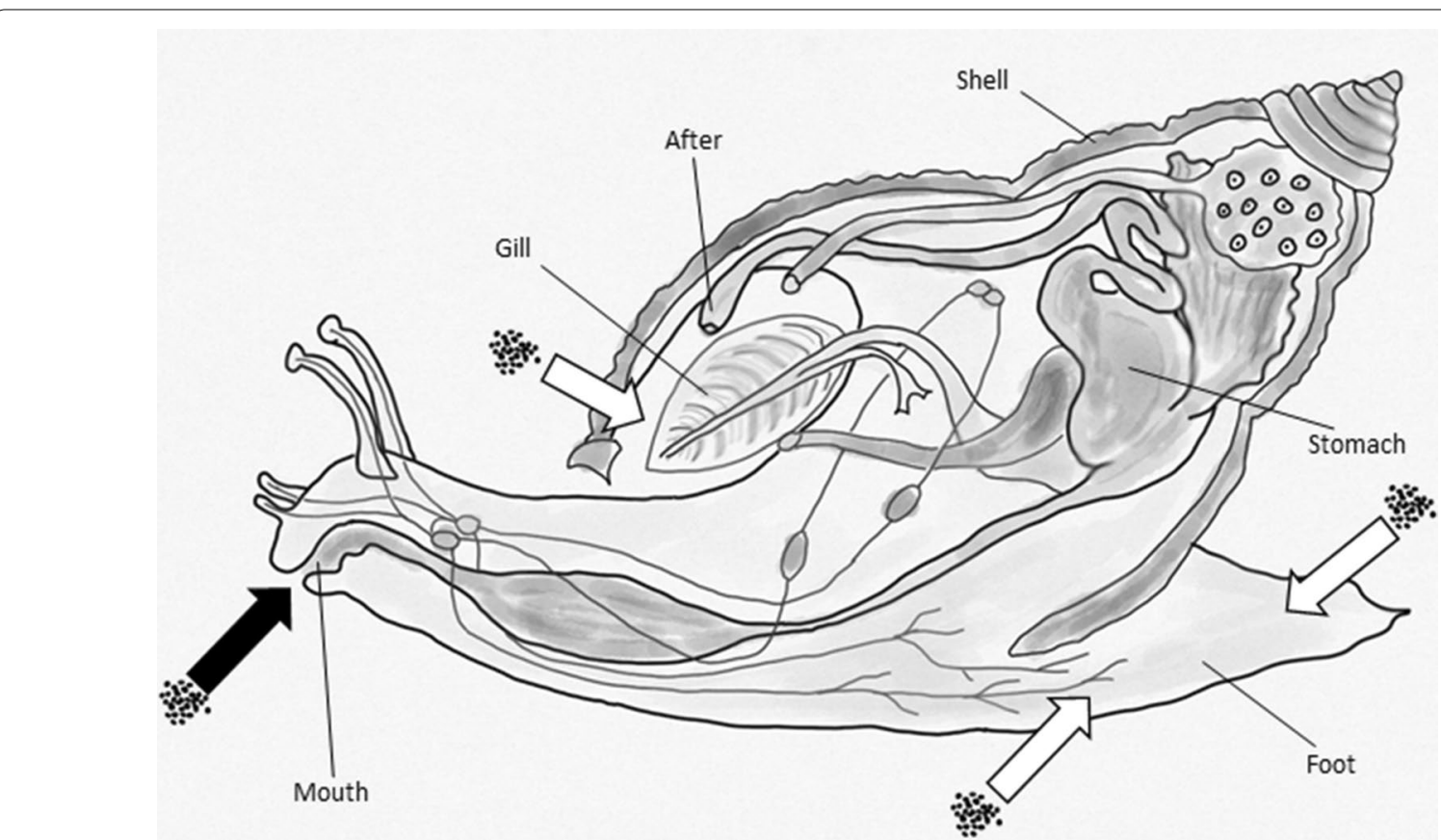

Fig. 2 Potential uptake routes of ENMs in Gastropoda. Black arrow: ingestion by the dietary route/ mouth; white arrows: uptake by the respiration/ gill (pulmonates) and passive uptake by the soft body tissues surface, e.g., foot

often higher than $99 \%$ until juveniles reach maturity [151, 184, 191]. Culture conditions are the same as described above for animal husbandry.

\section{Bioaccumulation testing}

Ideally, bioaccumulation experiments with snails are carried out under flow-through conditions. For flowthrough studies with organic soluble compounds, flow rates ranging from $7.5 \mathrm{~L}$ per day up to $22 \mathrm{~L} / \mathrm{h}$ were recommended [174, 192, 193]. Bioaccumulation tests with ENMs may need to be carried out with high flow rates to ensure a stable and homogeneous distribution of the test compound in the water [154]. The use of sediment in the test system is not recommended for bioconcentration studies which may be distorted by the dietary uptake of contaminated sediment. In contrast, several studies have used sediment as a source of ENM exposure [176, 177, 188]. In this case, a BAF/BMF rather than a BCF will be derived as the result of the bioaccumulation tests.

However, most bioaccumulation studies using ENMs or metals were carried out under semi-static conditions $[185,194]$ in different volumes of test media from $500 \mathrm{~mL}$ [195] to $10 \mathrm{~L}$ [196]. The age of the used animals in bioaccumulation tests with metals or ENMs ranged from 14 to 21 days [195] and up to 5 months [188]. Replicates were taken during the bioaccumulation studies and mostly consisted of several pooled animals, ranging from 10 animals (L. stagnalis) up to 30 animals (P. antipodarum) per replicate $[176,195]$ to reach sufficient biomass for sample analysis.

For tissue analysis usually only the soft tissue has been considered. In some studies the soft tissue was dissected into several compartments, like hepatopancreas, gonads, muscle tissue/foot, kidney, and digestive tract, giving the opportunity to investigate the distribution of the tested metals or ENMs [171, 177, 197]. By this, the hepatopancreas has been identified as the tissue with the highest accumulation potential for metals, presumably caused by the high content of metal-binding proteins $[177,188]$. However, Legierse et al. [154] mentioned that for measuring internal concentrations of the test item, the gut should be removed from the soft tissue and excluded from weight determination and tissue analysis.

Uptake phases of bioaccumulation experiments ranged from $6 \mathrm{~h}$ [198] up to four weeks [158, 188] for water exposure, and from $3 \mathrm{~h}$ [198] up to one week [176] for dietary exposure studies. The duration of the depuration phases were mostly in the same range, and in the study of Croteau et al. [199] the duration of the depuration phase was to two times the uptake phase.

Continuous feeding of snails during the test period is recommended to prevent starvation or alteration of metabolism due to fasting conditions. Daily feeding of lettuce, dried spinach, or fish food and removal of feces and feed residues has been the preferred method [158, 176, 177, 188]. Another feeding procedure is adding 
Spirulina algae powder or ground fish food to the vessel which sediments and can be ingested by grazing the bottom of the experimental tank [157, 200]. However, as a consequence, a rise of total organic carbon content in the test system is observed, which enhances adsorption of the test substances to organic matter [5, 197]. This potentially influences its bioavailability and thus the result of the bioconcentration experiment. To avoid this, further studies were carried out without feeding of the snails but only for short exposure periods to avoid the risk of fasting as mentioned above $[175,193]$.

For metal bioaccumulation the digestive gland plays an important role acting as a metal sink as shown for aluminum [186]. The gut of gastropods secretes mucus with a strong affinity for $\mathrm{Al}[185,201]$. Thus, the mucus could be a factor altering the uptake of metals because mucus glycoproteins are able to bind trivalent metals, like $\mathrm{Fe}, \mathrm{Zn}, \mathrm{Pb}$, and $\mathrm{Al}$ [202-204]. For the mostly bivalent metal $\mathrm{Cd}$, Coeourdassier estimated BCFs of 90-262 in the foot and 662-2602 in the viscera of $L$. stagnalis that are dose dependent with the highest values obtained for the highest concentrations [196]. However, for L. palustris, the estimated BCF values for $\mathrm{Cd}$ were up to 6000 and thus 9.4 times higher than those calculated for L. stagnalis. Accumulation of Cd (in combination with $\mathrm{Zn}$ ) was also observed in the species $\mathrm{Mel}$ anoides tuberculata and Helisoma duryi after a short aqueous exposure phase of about 6 h [198]. For the bioaccumulation of NPs, Gastropoda are often exposed via the dietary pathway. However, few studies have investigated the bioaccumulation of NPs in Gastropoda and these are mostly in combination with the dissolved form (e.g., Ag-NPs and $\mathrm{AgNO}_{3}$ ) of the same element to compare the bioaccumulation, uptake, and elimination of both forms [205].

It was shown that the accumulation of water-borne $\mathrm{Ag}$ and $\mathrm{Cu}$ from the dissolved form $\left(\mathrm{Ag}^{+}\right.$and $\left.\mathrm{Cu}^{2+}\right)$ is much higher than that from the nanoparticulate form $[32,177$, 188].

Bao et al. [177] exposed the freshwater gastropod $B$. aeruginosa to Ag-NPs and dissolved Ag and observed a higher uptake of $\mathrm{Ag}$ following exposure to the dissolved form leading to the highest burden in the hepatopancreas, followed by the gonads and digestive tract. Only low amounts of Ag were found in the foot tissue [177]. The distribution of the metals could be explained by the amount of metal-binding proteins and chelates in the respective tissues. Also, for dissolved $\mathrm{Cu}\left(\mathrm{Cu}^{2+}\right)$ a higher uptake compared to $\mathrm{Cu}$-NP exposure was observed in the same species, resulting in comparable tissue distributions [188].

Croteau et al. [199] described a protocol that allows the feeding of snails with algae which were previously exposed to NPs. That method was used for a dietary exposure study with $\mathrm{CuO}$-NPs. Feeding of the benthic diatom Nitzschia palea which was enriched with AgNPs and $\mathrm{Ag}^{+}$to L. stagnalis showed that the uptake rates were faster for $\mathrm{Ag}^{+}$than for Ag-NPs when both exposure scenarios are compared. During the depuration phase following dietary exposure, a very slow elimination of $\mathrm{Ag}$ with nearly no differences between both forms of $\mathrm{Ag}$ was observed. However, for aqueous exposure a faster elimination of Ag was observed if the Ag was presented as Ag-NPs. That means that the aqueous exposure may mainly lead to a simple ingestion of Ag-NPs that can be eliminated easily. A similar approach was successfully applied for ${ }^{67} \mathrm{ZnO}-\mathrm{NPs}$. Pre-exposed diatoms were used to expose L. stagnalis, resulting in comparable observations [206]. In a further study on L. stagnalis, only low bioaccumulation was observed for Au-NPs [11, 195] following dietary exposure.

\section{Isopoda \\ Biology and ecology}

The order Isopoda represents the first group of crustaceans considered in this work and contains more than 4000 described species. Besides, a few terrestrial species most isopods live in aquatic habitats. Aquatic isopods are benthic animals which are also able to swim. Gills for respiration are located at the base of the thoracic appendage and the integumentary surface is also used for gas exchange (Fig. 3).

Although the main part of the aquatic species lives in the sea, some species are native to freshwater systems. As benthic organisms, they are often used for ecotoxicological studies with sediment [207].

Asellus aquaticus has been described to be a useful biomonitor for organic and metal pollution in aquatic systems [208-214]. Due to their low sensitivity for brackish water, this species can be used in tests under freshwater and estuarine conditions [215-217].

Asellus aquaticus can be found in most European freshwater systems, streams, lakes, and nearly every surface water in Europe and North America [218-222]. It is often present in water systems close to sewage treatment plants or in lakes and other water systems with organic pollutants in higher concentration [223]. In the water system they live in littoral and sublittoral zones and reside on macrophytes, filamentous algae, litter, and stones [224, 225]. As most isopods, A. aquaticus is an omnivore and deposit feeding organism. As a nonselective feeder it feeds on detritus, periphyton, microscopic algae, small invertebrates, decaying vegetation, fungi, and bacteria [218, 219, 221, 225]. A. aquaticus is a very robust species and survives extreme environmental conditions, including hypoxic phases [207], and tolerates 
water temperatures of up to $28{ }^{\circ} \mathrm{C}$, and $\mathrm{pH}$ values down to 4.3 [207, 224, 226-229]. In contrast, A. aquaticus is very sensitive to heavy metal exposure being as sensitive as Gammarus or Daphnia [230]. The accumulation of metals from food and water in A. aquaticus has been described to strongly differ across several metals with some metals even showing no bioaccumulation potential [231]. For instance, aluminum is not accumulated from water at neutral $\mathrm{pH}$ conditions [232]. The differences in metal bioaccumulation were explained by the amount, binding affinity, and capacity of metal-binding proteins present in the isopods tissue used as part of the detoxification system [207, 214, 233, 234]. Sensitivity to metal exposure has been shown to be different for male and female animals as well as for different life stages (mature or juvenile) [230].

Another detoxifying strategy involves the sequestration of metals in Type B granules based on S-Type cells of invertebrates, leading to metal accumulation especially in the soft tissue close to the carapace and in the exoskeleton [235]. Rauch and Morris observed more than 20 times higher metal concentrations in the molted carapace than in the soft tissue of $A$. aquaticus [233]. This may also be explained by physical adsorption of metal ions to the exterior surface of isopods [232]. This must be considered in bioaccumulation studies, especially with respect to isopods which shed their exoskeleton causing an uncontrolled elimination [232].

The accumulation of metals and organic compounds in $A$. aquaticus plays an important role in the transfer of pollutants in the aquatic food chain [236]. As macro-invertebrate species, A. aquaticus represents an important food source for predatory invertebrates, several fish, amphibians, and waterfowl in the northern hemisphere [225, 237-242].

\section{Culture and breeding}

Most laboratory studies have been carried out with animals collected in the field which were then acclimated for a period of a few weeks up to several months under laboratory conditions [230-232, 243, 244]. The preferred culture conditions in a semi-static system include temperatures between 10 and $19{ }^{\circ} \mathrm{C}$ with around $240 \mathrm{mg} / \mathrm{L}$ $\mathrm{CaCO}_{3}$, a pH range of 7.2 to 7.4 , and a light:dark cycle of $14: 10$ or $16: 8 \mathrm{~h}$ [230-232]. However, due to the risk of parasite infection, e.g., by acanthocephalans, and the higher abundance of animals in contaminated water systems with high organic load and potentially leading to a high metal burden, laboratory culture of test animals is recommended [245-247].

Protocols for the laboratory culture of Asellus were described by Plahuta et al. [247] and McCahon and Pascoe [248]. 500-1500 juveniles per breeding container (1 L plastic containers) [248] were obtained from 100 females maintained in dechlorinated, aerated tap water. The isopods can be fed with Elodea or ash leaves [232]. However, the leaves should age in water or the applied culture media to enable colonization of a microbial community that can provide nutrients, such as vitamins, which are essential for the animals [221].

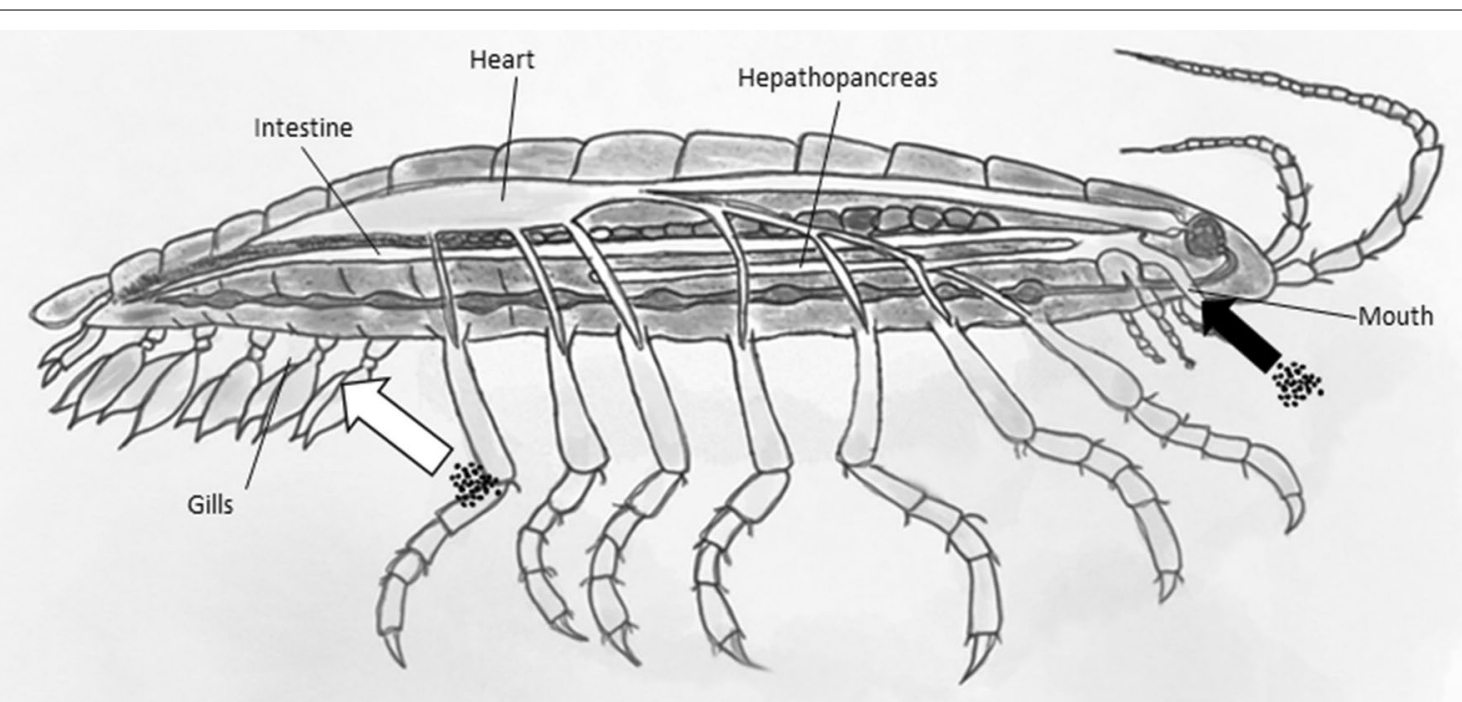

Fig. 3 Potential uptake routes of ENMs in Isopoda. Black arrow: ingestion by the dietary route/ mouth; white arrow: uptake by the respiration/gills 


\section{Bioaccumulation testing}

Asellus has been used for bioconcentration and biomagnification studies, in particular for investigations on metal accumulation [207, 241]. Water is the primary route of exposure for $A$. aquaticus [249] regarding environmental pollutants. Only for highly lipophilic chemicals uptake via food is important due to adsorption to organic particles [251,252], which may also be the case for ENMs [249, 250].

Both male and female animals of $A$. aquaticus have been used for bioaccumulation testing. However, only animals showing no apparent sexual or reproductive activity were used [249]. The size of animals used in the experiments ranged from 4 to $20 \mathrm{~mm}$ [230, 232, 244], which had fresh weights ranging from 7 to $28 \mathrm{mg}$ [220].

During tests the temperature ranged from 15 to $21^{\circ} \mathrm{C}$ and a photoperiod of $16: 8 \mathrm{~h}$ of light: dark was maintained [244]. In the case of short uptake periods, such as 2 to 5 days, animals were not fed [207, 243, 251]. During longer test periods isopods were fed with ash or Elodea leaves [232, 244].

Static test systems have often been used for metal bioaccumulation tests with spiked sediment as the source of exposure [207, 220, 231, 252]. Van Hattum et al. [231] used deionized and previously aerated $(24 \mathrm{~h})$ tap water as test medium, whereas Elangovan et al. [232] used standard snail water as described by Thomas et al. [178]. For the investigation of bioaccumulation of PAHs, van Hattum and Montañés [244] carried out a semi-static test with an uptake and elimination phase lasting 7 and 12 days, respectively [244]. Organic compounds were mostly tested in flow-through systems which should also be considered for testing ENMs to ensure homogeneous exposure conditions. Richter and Nagel [249] applied a medium exchange rate of around 1.5 exchanges per day $(1 \mathrm{~mL} / \mathrm{min})$ and observed no mortality during the test period, whereas van Hattum et al. [231] replaced the medium once per day in test vessels containing 20 animals. In this study cannibalism of the test animals was observed, which indicates an insufficient supply of nutrients or unsuitable test conditions causing stress [231]. Samples collected for chemical analysis included 4 to 25 pooled animals to ensure sufficient biomass for sample extraction $[207,220]$. Due to the potential of metal ions to sequester in Type B granules in S-Type cells located close to the carapace or exoskeleton, the soft tissues and exoskeleton should be analyzed as single compartments, e.g., as described for the terrestrial isopod Porcellio scaber by Kampe et al. [253].

Only one bioaccumulation study with ENMs using aquatic isopods has been described in the literature. Ekvall et al. [212] exposed A. aquaticus for 2 months to WC-NPs under static conditions. The body burden of pooled samples consisting of ten individuals was measured [212]. However, no BCF or BAF was calculated.

However, several studies have been carried out on the bioaccumulation of metals. van Hattum et al. [241] exposed $A$. aquaticus to $\mathrm{Cd}$ and calculated a BCF of 18,000 and a BMF of 0.08 . The uptake was shown to be independent of the $\mathrm{pH}$ of the exposure medium. The uptake by the dietary path represented only $50 \%$ of the complete Cd uptake [241] even at very high $\mathrm{Cd}$ concentrations in the food (220 times higher than in the water). For $A$. meridianus, both the uptake of $\mathrm{Cu}$ and the uptake of $\mathrm{Pb}$, following dietary and aqueous exposure, are described by Brown [254], whereby Eimers et al. [255] showed that for $\mathrm{Cd}$ the dissolved form is more bioavailable for $A$. racovitzai than $\mathrm{Cd}$ associated with particles [255]. In their work from 1993 van Hattum et al. described that cadmium and copper seem to be accumulated and stored in the organisms, whereas zinc and lead are rapidly eliminated [231]. Further, it has been reported that the accumulation of the metals palladium (Pd), platinum (Pt), and rhodium ( $\mathrm{Rh}$ ) seem to depend on the exposure time (BCFs: 150, 85, 7) rather than the exposure concentration [207]. The uptake rates of $\mathrm{Cd}$ measured in A. aquaticus are comparable with those reported for the bivalve Ruditapes decussatus and the snail L. stagnalis [165, 256, 257]. However, if exposed to mixtures of $\mathrm{Pb}, \mathrm{Cd}, \mathrm{Cu}, \mathrm{Ni}$, and $\mathrm{Zn}$, the uptake rates of $\mathrm{Cd}$ in $A$. aquaticus were shown to be higher than those reported for Daphnia magna when exposed to the same mixture of metals [258].

\section{Amphipods}

\section{Biology and ecology}

Amphipods often represent the dominant part of the benthic macro-invertebrate species in fresh water ecosystems [259]. They represent an important food source for several groups, like fish, predatory insect larvae, amphibian species, and water birds and are present during the whole year in contrast to insects which show a largely seasonal distribution [260-264]. The group of amphipods contains several species that are key species in aquatic ecosystems, playing an important role in the energy and nutrient cycling within the ecosystem, e.g., by breaking down leaf litter and their important role as a prey organism [263, 265-267]. By shredding decomposing leaves they mobilize small particles that can be ingested by filter-feeding organisms. The released feces can be readily decomposed by other organisms. Important food sources of amphipods can be water plants, such as Elodea spp., but also other macroinvertebrates and even small/ wounded fish species [259]. Also cannibalism has often been observed in amphipod populations. Gammarids are the most widespread group of amphipods in Europe 
(e.g., Gammarus fossarum or G. pulex) but are also present in North America (e.g., G. fasciatus or G. limnaeus) [268-270]. Hyalella azteca is an epibenthic amphipod which is widespread in North and Middle America [262, 271-274]. In the following sections we mainly focus on Gammarus sp. and Hyalella.

Gammarus pulex can reach an age of 1-2 years, depending on the environmental conditions, and mainly feeds on decaying leaves of deciduous trees, algae, insects, and other invertebrates [218, 261, 275]. Their growth is strongly temperature dependent and generally slower under low temperature conditions [276]. The approximate length of G. pulex is about $2 \mathrm{~cm}$, with males being larger and usually growing faster than females [275, 277]. G. pulex can represent up to $17 \%$ of the dietarybased energy ingested by young salmonids [278], and in some macroinvertebrate communities different Gammarus species can represent $28-38 \%$ of the biomass [259, 278].

H. azteca, in contrast to Gammarus, feeds on detritus by grazing on the sediment [279]. At the age of 20-30 days the first pairings appear. The number of offspring varies between 3 and 17 juveniles, depending on the age of the female [279]. H. azteca is described to be very tolerant against varying temperatures and low oxygen levels [262, 280].

Respiration of $H$. azteca mainly occurs via gills that are located at the thoracic segments (2-7), whereas G. pulex sometimes have an additional pair of gills on the first pair of gnathopds or pereopods [281, 282] (Fig. 4). The thin epithelium of the gills is primarily responsible for the exchange of ions, like $\mathrm{Na}^{+}, \mathrm{Ca}^{+}$, and $\mathrm{NH}_{4}^{+}$, but also other areas of the animals surface seem to be permeable for ions and are thus further locations of metal ion uptake [283-286]. While Vellinger [287] mentioned three theoretical ways of metal uptake for amphipods: (i) directly from food or water, (ii) through the cuticle, and (iii) diffusion across the exchange surface, Rainbow [288] explains that the crustacean exoskeleton is supposed to be almost impenetrable for dissolved metals [287, 288]. This is in line with the results of Vellinger [287], who showed for $G$. pulex that the strongest uptake of metals, as observed for $\mathrm{Cd}$, is through the permeable surfaces, e.g., of the gills. In this study the accumulation of $\mathrm{Cd}$ and As was observed, whereby the uptake of $\mathrm{Cd}$ was shown to happen via the gill membranes, whereas As $\left(\mathrm{as} \mathrm{As}^{5+}\right.$ ) was ingested through phosphate channels [287].

Following aqueous exposure of Cd, G. pulex has been observed to reduce the ventilator activity by reduction of the pleopods beats [289]. Comparable observations have been described for $\mathrm{Cu}$ and other heavy metals of sublethal concentrations [290, 291]. Another strategy to avoid toxic effects of metal exposure is the sequestration of free metal ions as described before for other species. Water born $\mathrm{Cd}$ is known to accumulate primarily in the gills and hepatopancreas of amphipods [292-294]. However, accumulated $\mathrm{Cd}$ and $\mathrm{Pb}$ were mainly found in insoluble fractions and particularly in metal-rich granules [295]. The role of metal-binding proteins and precipitation granules are further described by Koropatnick [296] or Ahearn [297]. Accumulated Ni was primarily localized in the cytosolic fractions of Gammarus sp. [298].

Another amphipod which has often been used for bioaccumulation tests is Diporeia spp a benthic organism which is known to be the most abundant macroinvertebrate in the Great Lakes. But its occurrence has sharply declined since the 1990s as a result of a change in the food web composition, probably caused by invading dreissenid mussels [299, 300]. Their formerly high abundance made them an interesting organism to test the toxicity and accumulation behavior of different compounds in the Great Lakes' region. For sediment toxicity tests it has been included as an alternative test organism in the ASTM guideline 1706-05 [301].

\section{Culture and breeding}

In previous laboratory studies, Gammarus sp. were mostly collected in the field and acclimatized for 1 up to more than 20 days to temperatures between 12 and $20{ }^{\circ} \mathrm{C}$ and kept under a light:dark regime of $16: 8 \mathrm{~h}$ or even under complete darkness [155, 250, 270, 302-305]. During the acclimation phase the animals are usually kept in dechlorinated tap water, artificial pond water, or commercial mineral water [306-310]. In contrast to Gammarus, which are difficult to breed in the lab, Hyalella can easily be cultured under laboratory conditions [311-315].

Using Gammarus sp. from the field brings the risk of using animals that are infected by parasites, like the acanthocephalan parasite Pomphorhynchus laevis. Infected animals show an altered feeding behavior that may be caused by damaged internal organs, including the hepatopancreatic ceca which is involved in the detoxification of stored metals. Thus, checking samples of the populations from which test animals are collected is essential. Parasites can be identified by dissection or by looking for orange spots that are visible through the carapace providing a clear indication for the parasite infection [316-324]. Effects of the infection on the concentration on metalbinding metallothioneins have been described, e.g., by Frank et al. [325] and Marijic et al. [326]. Further, a recent study showed that the cannibalistic behavior of G. duebeni celticus was greatly enhanced when infected with the microsporidian Pleistophora mulleri [327].

For G. pulex there is no broadly applied protocol that enables easy culture in the laboratory. First trials to 


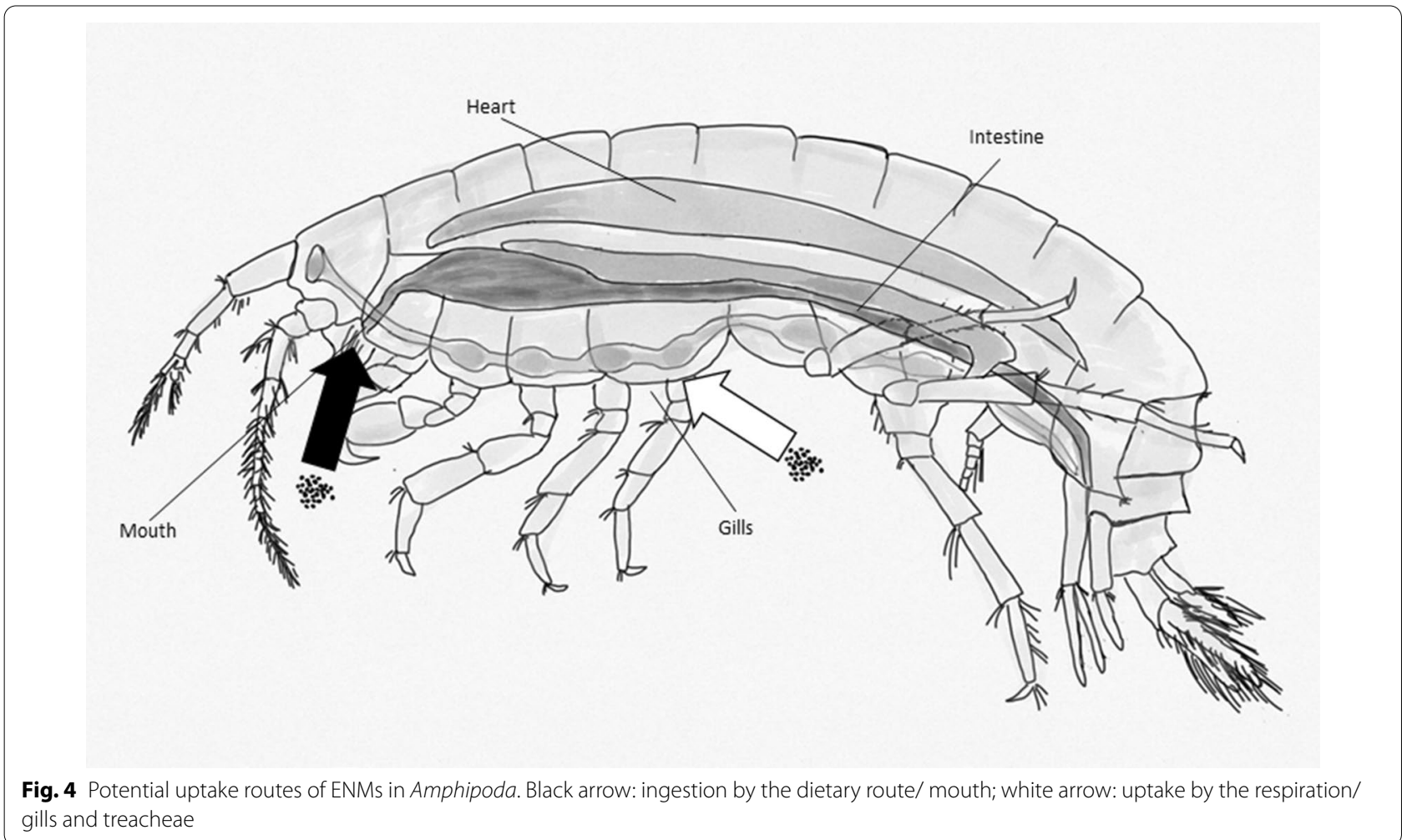

culture it for accumulation studies date back to the 1980s [275]. Probably the best known culturing procedure was described by McCahon and Pascoe who reported that approximately $70 \%$ of the juveniles survived and reached maturity obtained in a flow-through system with dechlorinated tap water which gets exchanged approximately every four hours $[248,306]$. Furthermore, illumination was for $12 \mathrm{~h}$ with a light intensity of $750 \mathrm{~lx}$; food consists of conditioned leaves of preferably horse chestnut leaves. Other feeding options are conditioned leaves of elm, oak, or sycamore. Algae are another food option, early juveniles feed on the adults' feces before they can feed on leaves [248, 270, 305, 306].

Brood sizes in Gammarus vary from approximately 6 to 29 eggs per female. 2 to 3 broods can be delivered per breeding season that in general lasts from spring to late autumn, followed by a breeding pause during winter [328]. McCahon and Pascoe [248] were able to determine a correlation between the age of G. pulex and the mean body length and mean antennal segment counts which simplifies age determination in test situations [248, 306]. An increased temperature and excess food reduces the time Gammarus needs to reach sexual maturity and to enable breeding in the laboratory throughout the year. Bloor et al. [329] adapted a culture method requiring approximately 200 gravid females for an output of 500-1000 juveniles with no or only negligible mortality.
Although these protocols apparently seem to provide an option to cultivate G. pulex in the laboratory, up to now these procedures are not broadly applied and a test procedure to establish G. pulex as a standard test organism is still absent [330]. A big problem in the culture of G. pulex appears to be cannibalism, with bigger animals often preying on smaller animals [331].

For $H$. azteca mass culture conditions have been reported by de March [332] and optimized by Borgmann et al. [334] and were used in different laboratories [121, 311-313, 332-335]. Animals have been mostly cultured in 1-2 $\mathrm{L}$ of standard artificial media containing bromide in polyethylene containers with a small piece of cotton gaze $(3 \times 3 \mathrm{~cm})$ providing a place of refuge. $A 16: 8 \mathrm{~h}$ light: dark photoperiod, water temperatures of $23-25{ }^{\circ} \mathrm{C}$, and feeding three times a week with periphyton or ground fish feed $\left(\right.$ TetraMin $\left.^{\circledR}\right)$ are optimal conditions for the culture of $H$. azteca [279, 334, 336, 337]. Wilder showed that the population density strongly influences growth, reproduction rate, and mortality of $H$. azteca in lab culture [338]. However, the easy culture providing a stable and homogeneous population makes $H$. azteca a clearly more suitable species for laboratory testing compared to Gammarus sp.

Diporeia spp. cannot be cultured in the lab and have to be collected from the field. In the lab, collected animals should not be held for longer than 2 months under static 
conditions because deterioration can be observed after this culturing period [301]. However, in some cases the lab culture could be maintained for up to several months [339].

\section{Bioaccumulation testing}

Gammarus pulex tests have been commonly conducted with static renewal of the test media, sometimes also as flow-through studies [155, 307, 340, 341]. Reported mortalities of control animals in G. pulex test systems are low and ranged from $0 \%$ in short-term experiments to below $2 \%$ mortality for populations held for two weeks under experimental conditions [155, 298, 340]. The low mortality confirms the suitability of the test systems for laboratory experiments. In several studies daily renewal of the test media was carried out [155, 298, 308, 342]. Xu and Pascoe [343] used a flow-through system providing a full exchange of the test medium in approximately $3 \mathrm{~h}$. Exposure periods ranged from $24 \mathrm{~h}$ to 4 days in tests with ENMs, the duration of the following depuration phases was in a comparable range [303, 312]. Feeding either consists of alder leaves or no feeding during the tests [270, $303,305]$. Mostly only males with a length of at least $8 \mathrm{~mm}$ were used for the tests [270, 303-305]. At each sampling point 3 or 4 replicates were collected, each consisting of 4 to 5 adult [303-305] or 10 juvenile animals which were further processed and analyzed as pooled samples [312].

Known to be good metal accumulators the species from the genus Gammarus may constitute a primary source of metals in the food chain [344]. The ability of $\mathrm{Cu}$ accumulation of Gammarus is comparable to that from Daphnia, but 9 times higher than reported for $H$. azteca [258, 345, 346]. Clason et al. [347] obtained BCFs for Cd (80-202), Cr (80-122), Cu (306), Pb (251-520), and $\mathrm{Ni}$ (23) in Gammarus by using a two-compartment model. In contrast Xu and Pascoe [343] used a modified first-order kinetic model, taking the basal level of essential trace metals into account, to calculate the uptake and elimination rate to predict the $\mathrm{BCF}$ of $\mathrm{Zn}$ in G. pulex. They proved the suitability of the model by agreement of the predicted and measured BCFs. Mehennaoui et al. [270] determined BCF values of 147 to 4238 for different water-borne Ag-NPs in G. fossarum. The $\mathrm{BCF}$ for $\mathrm{AgNO}_{3}$ was determined to be 2277. A comparable low BCF value of 176 was determined for $\mathrm{CeO}_{2} \mathrm{NPs}$ in G. roeseli by Garaud et al. [303].

$H$. azteca has been suggested by USEPA and Environment Canada, as a model organism to investigate sediment toxicity covered by an ASTM test method [190, 273, 301]. The potential of $H$. azteca as a test organism for bioconcentration studies with organic compounds was demonstrated by Schlechtriem et al. [313]. H. azteca has also been tested in bioaccumulation studies using ionic organic compounds [335, 348, 349].

Experimental setups with nanomaterials were conducted under (semi-)static and flow-through conditions with flow-rates of around 3 to $4 \mathrm{~L} / \mathrm{h}$ [311, 312, 315]. Feeding was carried out during the studies by using ground fish feed $\left(\right.$ TeraMin $^{\circledR}$ ) or DECOTABs as described by Kuehr et al. [315] that minimize the risk of artifacts due to uncontrolled exposure to ENMs that adsorb to the feed $[315,350]$.

Duration of uptake phases ranged from $24 \mathrm{~h}$ to 14 days, with similar durations for the following depuration phases [195, 311, 312]. For analysis, mostly 3 to 5 replicates were used each consisting of 10 to 20 animals [195, $311,312,314,315]$. Survival rates were not presented for all studies but ranged under flow-through conditions between 80 and 100\% [313].

Studies carried out according to the official guidelines usually assess sediment toxicity. Also some of the accumulation studies were conducted investigating the accumulation of contaminants from the sediment rather than from the water column [121, 312, 345].

The age of test animals varied in the bioaccumulation studies which have been conducted so far, but no detailed comparison regarding bioaccumulation potential depending on the life stage of $H$. azteca has been found in the literature. However, Alves et al. [345] stated that uranium uptake from sediments does not depend on the age of $H$. azteca.

$H$. azteca has been used in some laboratories as an organism to assess accumulation of metals, like $\mathrm{Cu}$, $\mathrm{Cd}, \mathrm{Zn}, \mathrm{Pb}, \mathrm{U}, \mathrm{Tl}$, or Hg. Alves et al. [345] showed by the example of $U$ that bioaccumulation of metals in $H$. azteca sediment tests is primarily based on the dissolved part and less from the sediment. Similar observations were described for other metals by other authors [346, 351-353]. Alves et al. [345] also showed that the bioaccumulation of $U$ is dose dependent and could be described and explained by the Biotic Ligand Modell of Paquin et al. [354]. Shuhaimi-Othmann and Pascoe $[355,356]$ showed that there is a rapid uptake and elimination of metals, with the exception of $\mathrm{Cd}$ that showed virtually no elimination $[355,356]$. This explains the high BCF of 31,803 for Cd that is significantly higher than those of $\mathrm{Cu}$ or $\mathrm{Zn}$ (BCFs of 1535 and 1060). It was also proven that a co-exposure of these metals influences their accumulation negatively.

The observation of the primary role of ions in the uptake of the metal is in agreement with the results of Kuehr et al. [314] who used methods of correlative microscopy to identify the main uptake pathway of silver from wastewater and/or sewage sludge-borne Ag-NPs. They also made similar observations for silver as made 
for Cd by Shuhaimi-Othmann and Pascoe [356] who observed virtually no elimination, potentially caused by the binding of $\mathrm{Cd}$ to metal-binding proteins $[314,356]$. Similar observations regarding the incomplete elimination of Ag were made by Kuehr et al. [98] after water and dietary exposure to Ag-NP or $\mathrm{AgNO}_{3}$. A special flowthrough system was applied described by Kuehr et al. [315] allowing the constant and homogeneous exposure of the amphipods by water or by using a diet that minimizes the dissolution of ions. During their studies they were able to determine $\mathrm{BCF}, \mathrm{BMF}$, and $\mathrm{BAF}$ values for $\mathrm{Ag}$ from $\mathrm{AgNO}_{3}, \mathrm{Ag}-\mathrm{NPs}, \mathrm{TiO}_{2}$ from $\mathrm{TiO}_{2} \mathrm{NPs}$, and $\mathrm{Au}$ from Au-NPs [315]. However, Hudson et al. used juvenile $H$. azteca in the age range of 7 to 14 days and observed no measurable uptake of Au-NPs by the young amphipods after $24 \mathrm{~h}$ of dietary exposure [195].

\section{Branchiopoda \\ Biology and ecology}

Cladocerans belong to the class of Branchiopoda (fairy shrimps) and are more commonly known as water fleas and encompass a group of so far 620 described species. In general, Cladocerans live in fresh water and usually represent a very important part of the food web. However, a small fraction has been identified living in brackish to saline waters, or are even considered as truly marine species [357]. The genus Daphnia has been studied for approximately 250 years already, resulting in a vast pool of information about this genus that so far has more than 100 known different species [358]. Depending on the species their body size varies from 0.5 to $6 \mathrm{~mm}$ [359]. Commonly used for ecotoxicological testing are the two Daphnia species Daphnia magna and Daphnia pulex.

The information about the biology of Daphnia are collected from reviews conducted by Herbert [358], Ebert [360], and Stollewerk [361] if not cited differently.

Daphnia are filter feeders, living pelagically in open waters. Animals consume small particles, such as algae, bacteria, fungi, protozoa, and organic debris, and represent an important part of the diet of a wide range of vertebrate (planktivorous fish) and invertebrate species, such as animals of the genus Chaoborus or Notonecta, and thus play a significant role in energy and nutrition flow of their ecosystems [362, 363].

For feeding they use their appendages to generate a water flow that funnels suspended material toward their mouth [364]. It is reported that Daphnia are only able to ingest particles bigger than $200 \mathrm{~nm}$ after filtering the water, due to the size of the space between the setulae on the thoracic limbs that are used to generate and sieve the water flow [365]. Also, the extraction efficiency of suspended particles depends on their size [366, 367]. Nevertheless, ENMs with smaller particle sizes suspended in the surrounding media may be ingested by direct intake due to passive drinking or incidental ingestion of the medium [368-370] (Fig. 5).

A Daphnia colony consists mainly of female organisms that reproduce via parthenogenesis into genetic clones. The diploid eggs reside within a dorsally placed brood chamber. The reproductive process is influenced by a variety of environmental factors with temperature being the most important one. A water temperature of around $20{ }^{\circ} \mathrm{C}$ represents optimal conditions for reproduction. At this temperature young hatch from their eggs in the brood chamber after only one day, then stay there for about 3 days before being released. A mature Daphnid is capable of releasing a brood every three to four days, lower temperatures increase this time. Furthermore, the onset of sexual maturation of Daphnids is delayed at low temperatures. The amount of offspring depends on the mother's size; therefore, a nutrient-rich environment promotes growth, resulting in bigger animals that in return can give birth to larger broods. When food becomes scarce or environmental conditions deteriorate, a trigger for sexual reproduction can be activated inducing sexual reproduction instead of parthenogenesis.

Waters inhabited by Daphnia show pH values of 6.59.5, the optimum appears to be in the range of 7.2-8.5. Their osmoregulation works via an uptake of chloride ions via absorbing glands. Oxygen distribution is facilitated by their hemoglobin-containing hemolymph, which Daphnids can regulate according to the oxygen availability in the water.

Blood cell-derived phagocytosis has been observed in Daphnia already in 1884 that may also allow the incorporation of previously ingested ENMs [371]. Bianchi and Wood [372] described for $\mathrm{Ag}^{+}$that the branchial epithelial cells of $D$. magna are capable of ingesting metal ions through $\mathrm{Na}^{+}$channels. It has been further described that the exposure to heavy metals and their released ions induce the expression of MTs and MT-like proteins in Daphnia [373, 374]. Fraysee et al. [375] observed that $75 \%$ of the complete body burden of D. magna after exposure to $\mathrm{Cd}$ was bound to MT. Wu et al. [376] described that the $\mathrm{Cu}$ content of molted carapaces of D. magna that have previously been exposed to CuO-NPs was as high as the total body burden of the Daphnids. Thus, the storage of metals in the carapace and the molting process that occurs approximately every two days may also represent a detoxifying and elimination strategy for metals in Daphnia.

Their worldwide abundance, sensitivity toward contaminants, important role in the food chain, and ability to 
be cultured in the lab have made Daphnia popular organisms for ecotoxicological testing. As a result, two OECD test guidelines have been developed over the years to assess the toxicity of chemicals with respect to two different factors. These are acute toxicity (OECD TG 202) and chronic toxicity (OECD TG 211) [377, 378] with immobilization and reproduction as the respective endpoints. Although both Daphnia pulex and Daphnia magna are accepted species for studies following both test guidelines, Daphnia magna is the commonly preferred species.

\section{Culture and breeding}

One of the reasons why Daphnia has gained popularity as a test organism is the option to easily culture it in the laboratory. As test medium well-filtered or spring water can be used $[379,380]$, but due to the demand for a standardized medium and general culturing conditions, the M4 and M7 media by Elendt [381] are recommended by the OECD guidelines [378]. However, Daphnia cultures do not appear to readily survive in Elendt media

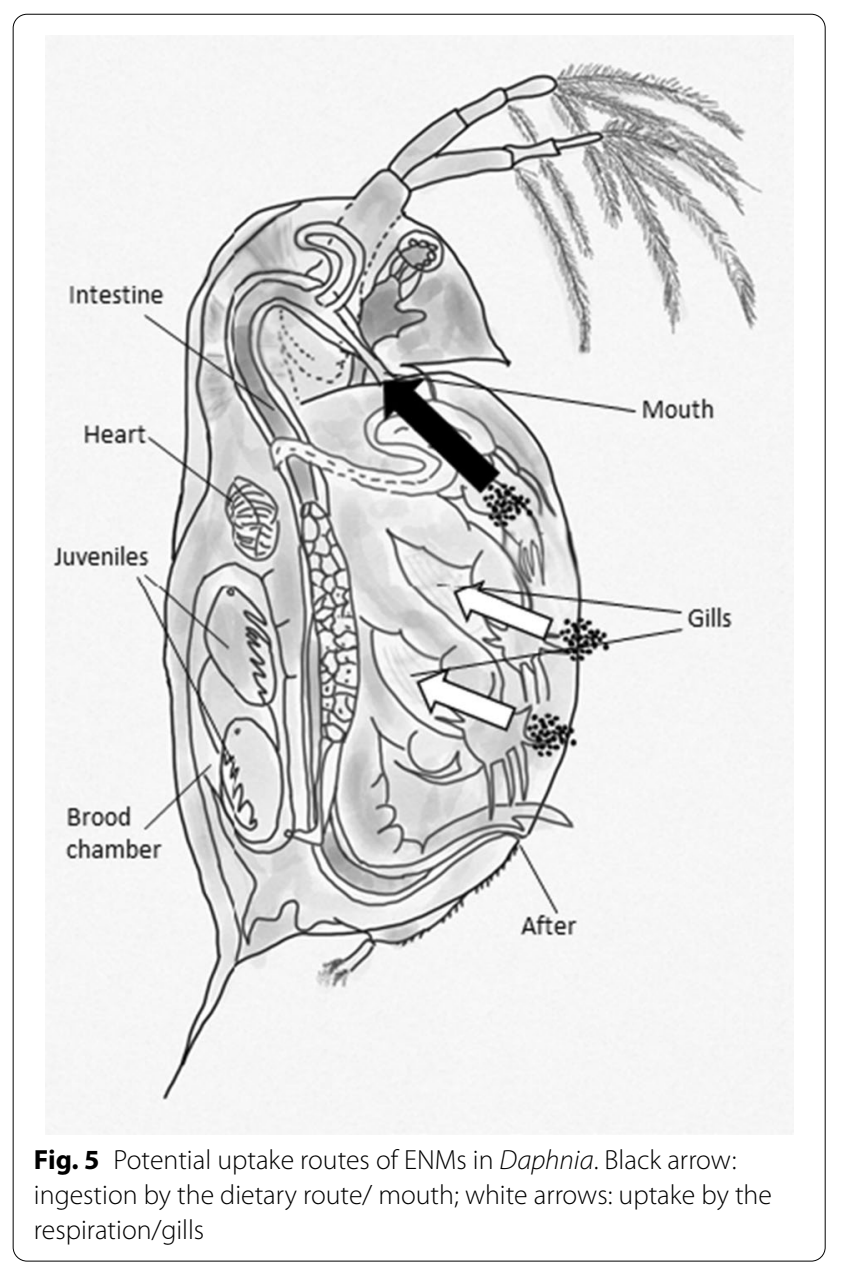

from the beginning, which is why a gradual acclimation to the medium over a period of up to one month is recommended.

A Daphnia culture should be monitored frequently. If Daphnia start to develop ephippia and male animals can be spotted, the culture is under stress and females produce eggs that can withstand unfavorable conditions. This has to be avoided and animals from such a culture should not be used for tests.

\section{Bioaccumulation testing}

Accumulation studies with Daphnia have been conducted already in the 1970s, investigating accumulation potentials for substances, such as DDT [382], anthracene [380], and $\alpha-\mathrm{HCH}$ [383]. For long-term experiments the usage of a medium with stable characteristics is sensible. Therefore, the media suggested for culturing should be also used for longer-term studies. In the case that metals or substances containing metals are tested, the use of test media, such as M4 and M7, containing EDTA, a chelating agent that binds metals, should be avoided. The OECD recommendation for an alternative test medium is reconstituted hard fresh water described in the ASTM guideline E 729-96 [384].

Dissolved oxygen of more than $3 \mathrm{mg} / \mathrm{L}$ can be achieved by constant aeration of the test medium prior to use. However, aeration during testing should be avoided (OECD TG202, TG211) since D. magna may die from small air bubbles in the medium [385].

Temperatures in Daphnia tests are usually in a range of $20-25{ }^{\circ} \mathrm{C}$ [386-389], but should not vary by more than $2{ }^{\circ} \mathrm{C}$ within a test [378]. Light intensities should be in a range of 1000-1500 lx of cool white light [378]. The light-dark cycle in bioaccumulation studies with ENMs varied from complete darkness [386, 387], 12:12 [390] and 14:10 [391,392] to $16: 8 \mathrm{~h}[393,394]$.

The OECD guideline 211 allows to either run a staticrenewal or a flow-through study which may help ensure constant exposure conditions. The ASTM guideline E1193-97 [395] describes different delivery systems suitable for Daphnia tests [396-398]. Accumulation studies using a flow-through system were described by Biesinger et al. [399] and Meinertz et al. [400].

The OECD TG 211 guideline suggests daily feeding in static renewal systems, but feeding in accordance to media exchange is also accepted. The food addition should not be too concentrated or too diluted. Food for Daphnia consists of green algae cells. Several algal species are suggested in the official guidelines. Other supplements proposed by the ASTM guideline E 1193-97 [395] are trout chow and yeast, but is only rarely applied [400402]. However, in bioaccumulation studies on ENMs feeding generally poses the risk of ENMs attaching to the 
food potentially leading to altered bioavailability and the uptake via different pathways (water and food) and thus only allowing the determination of BAF values.

So far accumulation studies have been performed with different compounds, including several metal and metal oxide ENMs. The age of Daphnids used for (bio)accumulation studies varied significantly and there is no recommendation for a preferred age. In the literature studies are found using neonates [386-388, 391, 403-406] as well as using adults [393, 394, 407-410]. In most cases, 3 replicates per sampling point were used, each consisting of 10 adult individuals. In the case of collecting neonates, replicates could consist of up to 100 animals $[388,403]$. The volume of the test/exposure medium was mostly in a ratio of 5 to $10 \mathrm{~mL}$ per animal and all tests were conducted under static or semi-static conditions. Information on the feeding regime during bioconcentration studies is not always available. However, in some studies no feeding was applied [408, 411]. Feeding of the animals during bioconcentration studies was leading to a faster and more effective elimination of body burden, but no alteration in the uptake of the test items was observed [387, 388, 412]. Some studies investigated the uptake of ENMs by the dietary path and described methods to generate algae-based, pre-exposed diets [389, 410, 413].

The length of the uptake phase of Daphnia bioaccumulation studies ranged from $30 \mathrm{~min}$ [391] and 5 or $6 \mathrm{~h} \mathrm{[388,}$ 414] up to 2 days [392, 404, 408, 410]. Depuration phases were sometimes longer than the corresponding uptake phase ranging from $24 \mathrm{~h}[387,414]$ up to 3 days [388].

Several studies observed the uptake of ENMs by $D$. magna and their accumulation in the gut region [19, 387, $389,390,403,404,406,412]$. The availability of the particles is explained by the mostly higher hydrodynamic diameter that allows the extraction and uptake of these particles from the surrounding medium, even with core sizes smaller than the mesh size of the daphnids setula [414]. Regarding the uptake of ENMs into epithelial cell membranes, the transfer by clathrin-mediated endocytosis is discussed [414-416]. However, there was no clear evidence for the real bioaccumulation/incorporation of ingested ENMs into the tissue or single cells or their membranes [404, 406, 407, 417, 418] as confirmed by histological investigations using electron microscopy. However, the simple ingestion of ENMs may still cause increased body burdens as described for $\mathrm{Cu}$-NPs and $\mathrm{ZnO}-\mathrm{NPs}[387,408]$. High BCF values were determined for ionic Ag which can be explained by the fast uptake mechanism due to the high affinity of $\mathrm{Ag}^{+}$to membrane transporters, like $\mathrm{Na}^{+}$channels $[372,410]$. Also the release of ions from ENMs may thus contribute to the body burden of exposed animals. In most studies on metal bioaccumulation in Daphnids, uptake and elimination kinetics were derived but no steady-state $\mathrm{BCF} / \mathrm{BAF}$ or BMF values were reported. Only in a few studies bioaccumulation endpoints were determined. For $\mathrm{TiO}_{2}$-NPs BCF values ranging from 1230 (after $24 \mathrm{~h}$ of exposure at $1 \mathrm{mg} / \mathrm{L}$, with food) to 118,000 (after $24 \mathrm{~h}$ of exposure at $1 \mathrm{mg} / \mathrm{L}$ without food) for adults [412] and from 21,200 to 145,350 for juveniles (after $24 \mathrm{~h}$ of exposure to 1 and $10 \mathrm{mg} / \mathrm{L}$, respectively) were reported [389]. BMF values for $\mathrm{TiO}_{2}$-NPs were concentration dependent with higher values for higher exposure concentrations and ranging from 5.7 to 122 in juveniles after $24 \mathrm{~h}$ of exposure [389]. Higher BAF values of 132-214 were observed after $48 \mathrm{~h}$ of exposure in a bioaccumulation study with Ceriodaphnia dubia [413]. In contrast, lower $\mathrm{BCF}$ and BMF values were reported for silver after exposure of Ag-NPs for $48 \mathrm{~h}$ to adult D. magna [410] with values of $3-5$ and 0.5 , respectively.

\section{Evaluation of aquatic invertebrate species for testing bioaccumulation of ENMs}

Data that are suitable to be used in the regulatory risk assessment of ENMs and that potentially allow a waiver of further tests using vertebrates, like fish, need to be generated in bioaccumulation studies carried out using experimental procedures with test species that fulfill special requirements. These requirements include constant exposure conditions and ideally a worst-case scenario regarding the availability and accumulation of ENMs by the test organisms. Several groups of invertebrates were described in this literature study that may be suitable test organisms for bioaccumulation studies with ENMs. A summary of the characteristics of the different species as test organisms is provided in Table 2.

Due to the high filtration rate and thus potentially increased ingestion of ENMs from the exposure media, filter feeding seems to represent a worst-case scenario regarding the bioaccumulation of ENMs. Bivalves and Daphnia sp. (Branchiopoda) are filter-feeding species with different morphological and physiological characteristics.

For Daphnia sp. breeding protocols are available and well established, whereas bivalves must be collected from the field due to a lack of suitable lab breeding protocols. Nevertheless, the high reproduction rate of daphnids can be disadvantageous. The release of the parthenogenetic juveniles as well as the molting rhythm of around $48 \mathrm{~h}$ constitutes an irregular, inhomogeneous elimination mechanism for previously accumulated contaminants. This only allows generation of suitable data in studies with short durations and this may explain the lack of evidence for incorporated and thus bioaccumulated ENMs in Daphnia sp. Due to the lack of a flow-through system which has been proven to allow the continuous and 
homogeneous exposure of ENMs, Daphnia sp. seem to be a less suitable group for bioaccumulation testing. This is the case even if there is a broad experience in testing metals and their bioaccumulation in these species. Another limitation of bioaccumulation testing with Daphnia is the endpoint obtained which rather represents a BAF than a clear BCF or BMF. This is due to the filtration activity for respiration and feeding and the passive drinking for osmoregulation. This also limits the use of bivalves which show, however, further benefits for bioaccumulation testing. For instance, a flow-through system is available allowing the constant exposure of the test animals with ENMs. The duration of bivalve bioaccumulation studies is in a time frame that may allow the incorporation of ENMs by mechanic and physiological processes but is still shorter than the time required to perform a classic fish study according to OECD TG 305. During bivalve bioaccumulation studies no reproduction and thus uncontrolled elimination by the release of larvae/ juveniles occur and there is no risk of significant growth effects. The size of the individuals allows the determination of tissue-specific accumulation and distribution factors. The characteristics of the soft tissue also enables the preparation of samples which can be further investigated for particle concentrations replacing total mass concentration. In addition, the size allows characterization of the test animals and the usage of homogeneous test batches. This is due to the fact that the shell size correlates with the filtration activity and thus the uptake and accumulation potential for ENMs. A broad literature base is given for the accumulation processes of metals in bivalves, including the pronounced detoxifying strategies including MT.

The biological-related group of gastropods is comparable to bivalves but shows several limitations for bioaccumulation testing. Although there are protocols for dietary exposure of ENMs, the highly permeable body surface (soft tissue) of the animals may allow the uptake and thus co-exposure of ENMs or ions, via dietary and aqueous exposure. The most used pulmonate $L$. stagnalis should be used with caution because air-breathing pulmonates move to the water surface and may remain some time without being exposed to the contaminated water/test medium. Regarding biological and individual variations, the time spent without full exposure may cause artifacts in BAF calculation due to inhomogeneous exposure conditions within one treatment or study.

Even if isopod bioaccumulation studies seem to be a promising approach, there are only a few data available on the bioaccumulation of ENMs and metals in this group. The high sensitivity to metals is critical, and therefore, appropriate exposure concentrations are required, resulting in concentrations that can be challenging for the subsequent sample analysis. Further studies are required to allow a thorough assessment of isopods as suitable species for bioaccumulation testing of ENMs. Using isopods for bioaccumulation testing would allow derivation of distinct $\mathrm{BCF}$ or $\mathrm{BMF}$ values.

A suitable flow-through system for ENM exposure and protocols for dietary exposure without the risk of uncontrolled co-exposure via the water are available for amphipods, in particular for $H$. azteca which allows derivation of distinct $\mathrm{BCF}$ or $\mathrm{BMF}$ values. The easy culture and breeding methods described allow the production of high amounts of test animals of the same age under laboratory conditions. With respect to the duration of the exposure and elimination phases of the given bioaccumulation studies and short times required to reach steady-state conditions, the usage of adults with an age above 8 weeks (showing slow growth) will reduce the risk of growth effects to a negligible level. Even if the organism is too small to allow a tissue or compartment-based analysis after dissection, there are protocols and methods available that may allow the localization of ENMs in the different tissues by imaging methods or measurements, like spICP-MS. Considering the broad knowledge on the

Table 2 Characteristics of the reviewed invertebrates; ${ }^{*}$ metal or metal oxide-based ENMs; ${ }^{*}$ dissection of different compartments for investigations on biodistribution possible; .d. = not described;

\begin{tabular}{|c|c|c|c|c|c|}
\hline Category & Bivalvia & Gastropoda & Isopoda & Amphipoda & Branchiopoda \\
\hline Endpoints & BAF & BAF (BMF) & $B C F, B M F$ & $\mathrm{BCF}, \mathrm{BMF}$ & BAF \\
\hline Literature_-biology \& physiology & ++ & ++ & + & ++ & +++ \\
\hline Literature \& data—metal uptake/ accumulation & + & ++ & ++ & ++ & ++ \\
\hline Literature \& data—ENM* uptake/ accumulation & + & + & - & + & ++ \\
\hline Reproduction in lab & - & + & ++ & +++ & +++ \\
\hline Lab culture & + & ++ & ++ & +++ & +++ \\
\hline Size of organisms &,$+++{ }^{* *}$ &,$+++ * *$ & + & ++ & ++ \\
\hline ENM* exposure test system &,++ for BAF & n.d & n.d &,+++ for BCF \& BMF & + \\
\hline
\end{tabular}


ecology, physiology, metal uptake process, and detoxifying mechanisms of amphipods as well as the long-term experience obtained from metal bioaccumulation studies with amphipods and the growing experience with ENMs, the benthic species $H$. azteca could play a key role in the bioaccumulation assessment of ENMs. Even though $H$. azteca represents the most promising species for bioaccumulation studies with ENMs as summarized in Table 2, further ENMs with different characteristics need to be tested to extend the knowledge on ENM bioaccumulation in freshwater amphipods and to allow a final assessment of their general suitability to be used as test organisms within a tiered testing strategy for ENMs.

\section{Note of guidance for the use of bioaccumulation endpoints derived from studies using aquatic invertebrate species in the risk assessment process for ENMs}

We propose a testing strategy representing a modified version of the tiered approach proposed by Handy et al. [30] (Fig. 6, left), including an assessment scheme with the aim of defining a "bioaccumulative" or "non bioaccumulative" grading for ENMs without using fish (Fig. 7). In addition, we propose decision criteria/endpoints that are more robust regarding the analytical challenges involved in ENM studies as described by Petersen et al. [33]. Due to the special properties of ENMs, the classical endpoints gained in bioaccumulation studies with ENMs, like BCF, $\mathrm{BMF}$, or BAF, cannot or should not be derived as is normally the case for dissolved/ water-soluble test items.

Petersen et al. [33] explained that the usage of kinetic endpoints, like $\mathrm{BCF}_{\mathrm{kin}}$ or $\mathrm{BAF}_{\mathrm{kin}}$, that are not based on steady-state conditions would be of more value. They mentioned that steady-state conditions may be observed in laboratory studies, but may not occur in aquatic systems under environmental conditions [33]. However, steady-state conditions that are observed during the laboratory studies still represent a worst-case scenario and are thus suitable for regulatory assessment. In addition, as mentioned by Handy et al. [30] the calculations of uptake and elimination kinetics $\left(\mathrm{k}_{1}\right.$ and $k_{2}$ ) used for calculation of kinetic $\mathrm{BCF}_{\mathrm{k}}$ are based on the usage of the Michaelis-Menten kinetics and the Fick equation. Thus, information on the thermodynamical stability and free ion activity are required [30]. But ENMs diffusion in liquids is based on Brownian motion and the particle concentration and the given energy of the system (suspension/dispersion). Further the collision frequency determines the fate of the particles, regarding the behavior to form agglomerates or not and thus this is much more complicated to be modeled and kinetic approaches will be more inaccurate $[419,420]$. Thus, a non-kinetic test design is suggested as outcome of this literature review. A tiered approach for testing ENMs in invertebrates is described allowing to derive endpoints (BCF and BMF) which can be assessed using the established threshold values for bioaccumulation assessment.

In Tier 1 the chemical and physical properties of the ENM are reviewed.

At the first step of Tier 1, (Fig. 6) the potential ability of dissolution or ion release in water or lipids is tested. If the material produces ions or dissolves in water or lipids, the ionic/dissolved form of the ENM should be tested as a second treatment (aqueous exposure) in the following in vivo bioaccumulation tests with invertebrates of Tier 2 .

As a second step of Tier 1 the ENM's potential to generate a homogeneous and stable exposure scenario under aquatic conditions is elucidated (Fig. 6). If there is only a limited or even no chance to generate a continuous and homogeneous exposure scenario by the surrounding media /water, a dietary-only exposure scenario is recommended as described by Kuehr et al. [98] for the amphipod H. azteca using ENM-enriched DECOTABs.

In contrast to the assessment scheme proposed by Handy et al. [30] exposure pre-tests with the amphipod $H$. azteca are carried out in the first step of Tier 2 to determine suitable test concentrations for the bioaccumulation tests. In addition to that, the availability of the test item for the test organisms and the resulting potential loading capacity of the ENM and its potential ions/ dissolved form is determined. H. azteca is suggested as test organism to determine clear BCF and BMF values as endpoints that can be used within regulatory assessment.

As mentioned by Kühnel and Nickel [20] an endpoint based on the measured body burden needs to be assessed with caution due to the challenging differentiation between the burden resulting from ENMs attached to the animals surface or simply ingested and those really incorporated and thus bioaccumulated. Information about the half-lives of the body burden offers important information about this and thus plays an important role in the presented assessment scheme (Fig. 6; Part 2 of Tier 2).

As a first step, the bioavailability of the test compound (ENM) needs to be confirmed. The exposure should last 7 days and the exposure concentration should be at a low level, if possible, mirroring the predicted environmental concentration to avoid artificial results regarding the bioavailability and bioaccumulation of ENMs [6]. If the measured body burden of the animals is higher than the measured initial natural background plus the limit of quantification (LOQ) defined as 9 times the limit of detection of the respective test item, a significant loading capacity for the tested ENMs is given. The measurements should be carried out on the level of total mass concentrations. If 

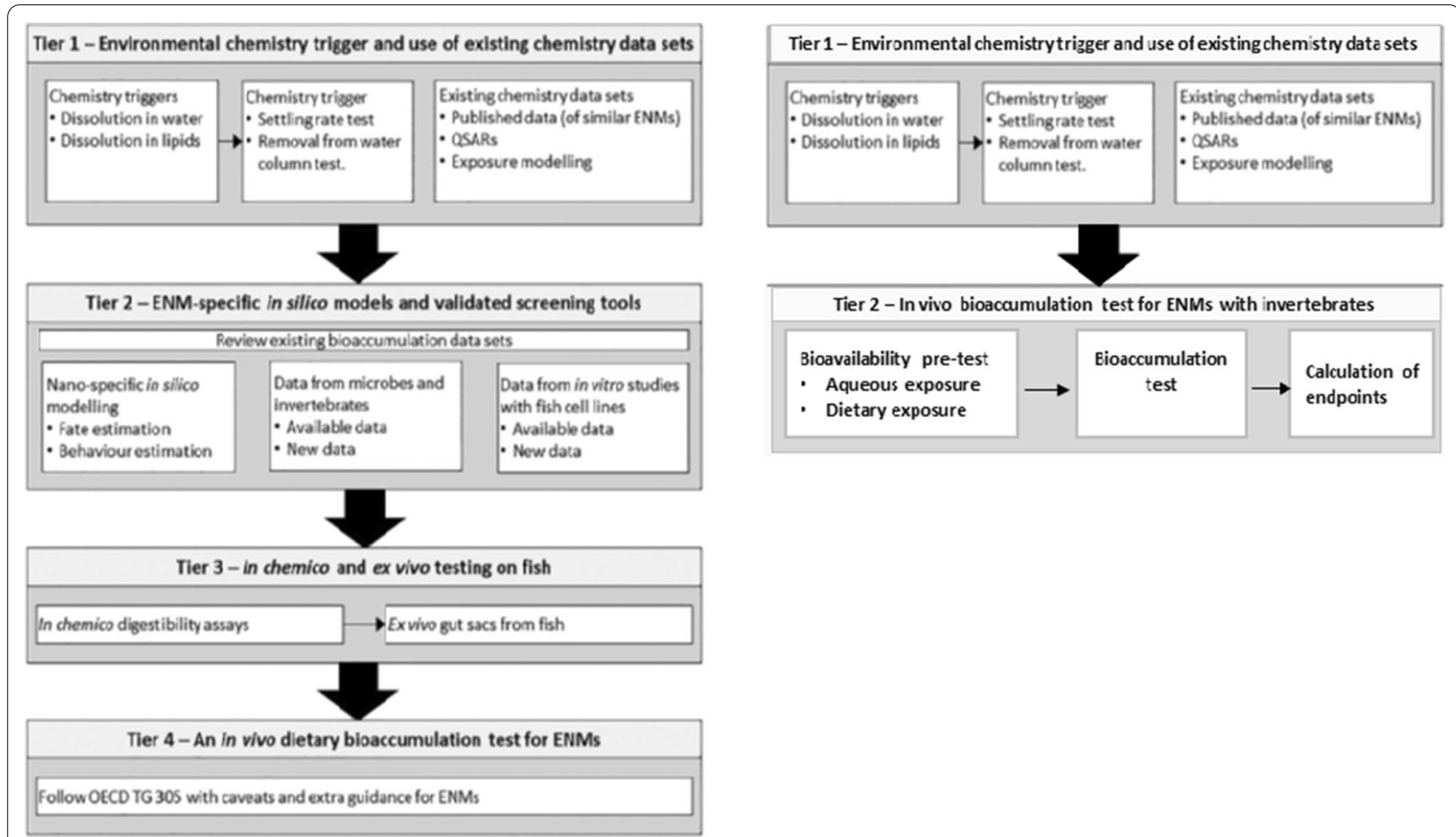

Fig. 6 Left: tiered approach for testing nanomaterials by Handy et al. [30], right: modified test approach according to Handy et al. [30]

no significant loading capacity can be achieved during 7 days of exposure, the tested ENM could be graded as "non bioaccumulative." If a significant loading capacity is reached within 7 days or less, bioconcentration and biomagnification tests for the ENM and, if necessary, a bioconcentration test for the ionic/dissolved form should be carried out. These tests must include a depuration phase to allow estimation of the half-life of the previously ingested/accumulated (?) ENMs.

The uptake phase of the bioaccumulation tests (bioconcentration or biomagnification approach) should last at least as long as required that three subsequent body burden measurements $\left(\Delta_{t} \geq 12 \mathrm{~h}\right)$ show no variation higher than $20 \%$ allowing the calculation of a time-weighted loading capacity (TWLC) for the end of the uptake phase based on the three last measurements.

As a result of the second study bioconcentration and biomagnification factors are calculated by dividing TWLC by the exposure concentration in water or food, respectively. If the values are below the threshold value of $2000\left(\mathrm{BCF}_{\mathrm{TWLC}}\right)$ or $1\left(\mathrm{BMF}_{\mathrm{TWLC}}\right)$, the tested ENM can be graded as "non bioaccumulative," provided that the common threshold values are accepted for ENM bioaccumulation assessment. Generally, if one of the calculated endpoints shows a value above the set thresholds, the results need to be further validated based on the depuration behavior of the previously accumulated test item.

Thus, the body burden of the animals needs to be further elucidated during a depuration phase following exposure of the second study. For the depuration phase two outcomes for the elimination of the ENMs are possible, leading to two grading scenarios: First, the elimination of the previously measured ENMs occurs fast and completely; the level of the body burden has a halflife of $\leq 1$ day. This scenario has been observed for AuNPs in $H$. azteca by Kuehr et al., where the determined BCF value of $>400$ indicated a certain loading capacity [315] and a level below the measured initial natural background plus the LOQ was reached within $\leq 1$ day of depuration. This scenario indicates that the body burden and the loading capacity may primarily result from simply ingested, but not incorporated, and thus not bioaccumulated material, i.e., located in the gut (content) or attached to the animals surface. This outcome would lead to a decision for a "non bioaccumulative" grading if fast elimination is observed following aqueous or dietary exposure.

In the second scenario a slow or incomplete elimination is observed during the depuration phase following one or both exposure scenarios: If the elimination halflife is $>1$ day, the depuration phase is extended until 
Tier 1 - Environmental chemistry trigger and use of existing chemistry data sets

Release of ions?

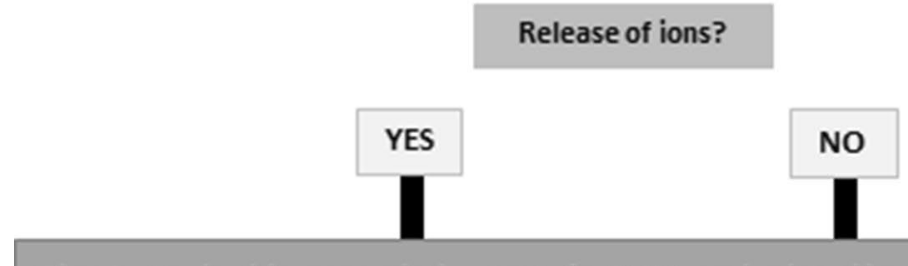

Tier 2 - In vivo bioaccumulation tests for ENMs and related ions with amphipods (H. azteca)

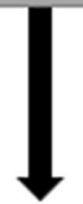

H. azteca

bioconcentration

\& biomagnfication test

Treatments:

- 1 ENM (BCF, BMF)

- 2 lonic form (BCF)

Treatments:

- 1 ENM (BCF, BMF)

Is there a loading capacity?

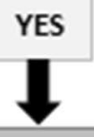

BCF $_{\text {TwLC }} \geq 2,000$ ?

and / or

BMF $_{\text {TwLC }} \geq 1$ ?

YES

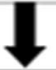

Is a fast \& complete elimination given ?

No

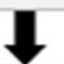

BCF $_{\text {TWRC }} \geq 2,000$ ?

and / or

$\mathrm{BMF}_{\mathrm{TWRC}} \geq 1$ ?

YES

I

$\underline{\text { bioaccumulative }}$

Fig. 7 Assessment scheme for bioaccumulation assessment of ENMs; ${ }^{*}$ if $B C F_{T W R C}$ is $\geq 2000$ or $\geq 5000$, and $B M F_{T W R C} \geq 1$, the test item is classified as "bioaccumulative" or "very bioaccumulative," respectively, and a higher tier test could follow to refine the calculated endpoint 
either the burden reaches the initial natural background concentration or three subsequent body burden measurements $\left(\Delta_{\mathrm{t}} \geq 12 \mathrm{~h}\right)$ show that the residual body burden values do not vary by more than $20 \%$ (sink). Under these conditions bioconcentration and biomagnification factors are calculated based on the time-weighted residual capacity (TWRC) and the exposure concentrations. The ENM is graded as "bioaccumulative" if these values are above 2000 for $\mathrm{BCF}_{\mathrm{TWRC}}$ and 1 for $\mathrm{BMF}_{\mathrm{TWRC}}$. Such a scenario was observed in an amphipod bioaccumulation study with Ag-NPs as well as in a bivalve bioaccumulation study with the same test item by Kuehr et al. [98, 315].

If only the ionic/dissolved form shows $\mathrm{BCF}_{\mathrm{TWLC} / \mathrm{TWRC}}$ values above the threshold of 2000, but not the respective ENM tested in the bioconcentration approach, the ENMs have to be considered as "non bioaccumulative." With the $H$. azteca bioaccumulation tests leading to higher $\mathrm{BCF} /$ BMF values compared to fish as shown for Ag-NPs and $\mathrm{TiO}_{2}$-NPs [17, 315], the invertebrate test can be seen as a worst-case approach and further tests using fish can be waived if a clear grading was made following the assessment scheme presented in Fig. 7. If the calculated value for $\mathrm{BCF}_{\mathrm{TWRC}}$ is $\geq 2000$ or $\geq 5000$, the test item should be graded as "bioaccumulative" or "very bioaccumulative."

Although the focus of the review part of this work is on metal and metal oxide-based ENMs, the proposed testing approach (Fig. 6), including the assessment scheme (Fig. 7), can be used for all types of ENMs, e.g., polymer- and carbon-only-based ENMs. This approach may also be useful for further testing and the regulation of microplastics. However, more information and data are required to confirm the suitability of this approach for the testing and assessment of microplastics.

\section{Conclusion}

The literature study has elucidated the potential of different aquatic invertebrate species to be used in laboratory bioaccumulation studies on ENMs. Amphipods were identified as the most promising species for ENM testing. Individual BCF and BMF values can be calculated that fulfil the requirements of endpoints needed for the bioaccumulation assessment of ENMs under regulations, like REACH. The results from amphipod bioconcentration and biomagnification tests can be included in a tiered assessment allowing a clear grading of the tested nanomaterials as "bioaccumulative" or "non bioaccumulative." Due to the worst-case scenario of the amphipod test, this approach may allow to waive further vertebrate tests if there are no indications for bioaccumulation of ENMs. In case, that bioaccumulation of ENMs is observed in Hyalella azteca a fish test as the golden standard of bioaccumulation testing should be considered.

\section{Abbreviations}

BAF: Bioaccumulation factor; BCF: Bioconcentration factor; BMF: Biomagnification factor; ENM: Engineered nanomaterial; LOQ: Limit of quantification; MT: Metallothioneins; NPs: Nanoparticles; TWLC: Time-weighted loading capacity; TWRC: Time-weighted residual capacity.

\section{Acknowledgements}

Critical comments on a former version of the manuscript by Dr. Doris Völker and Dr. Kathrin Schwirn are highly acknowledged.

\section{Authors' contributions}

SK and CS conceptualized and coordinated the preparation of the manuscript and developed the assessment scheme. SK carried out the literature research and analysis of the literature. VK contributed to the literature research of the chapters "Amphipods" and "Branchiopoda." SK mainly wrote the manuscript. CS supported to further elaborate the manuscript and contributed specific aspects. All authors read and approved the final manuscript.

\section{Funding}

Open Access funding enabled and organized by Projekt DEAL. This study was funded by the Fraunhofer Institute for Molecular Biology and Applied Ecology IME.

\section{Availability of data and materials}

Not applicable. Data sharing is not applicable to this article, as no datasets were generated or analyzed during this study. The data are based on published articles and reports.

\section{Ethics approval and consent to participate}

Not applicable.

\section{Consent for publication}

Not applicable.

\section{Competing interests}

The authors declare that they have no competing interests.

\section{Author details}

${ }^{1}$ Department Bioaccumulation and Animal Metabolism, Fraunhofer Institute for Molecular Biology and Applied Ecology IME, Auf dem Aberg 1, 57392 Schmallenberg, Germany. ${ }^{2}$ Department Chemistry and Biology, "Ecotoxicology"Work Group, University of Siegen, 57068 Siegen, Germany. ${ }^{3}$ Department of Ecosystem Analysis, Institute for Environmental Research, RWTH Aachen University, Aachen, Germany.

Received: 13 September 2020 Accepted: 30 November 2020 Published online: 17 January 2021

\footnotetext{
References

1. ECHA. Guidance on information requirements and chemical safety assessment chapter R.11: PBT/VPvB assessment. Eur Chem Agency 4:494, 2017, https://doi.org/10.2823/128621.

2. Ministry of Environment and Urbanization (MoEU) of Turkey (2017) Draft by-law on registration, evaluation, authorization and restriction of chemicals. http://files.chemicalwatch.com/KKDiKingilizce.pdf. Accessed 4 Jan 2018

3. USEPA (2004) High Production Volume Challenge Program. vol. C. www. epa.gov. Accessed 4 Jan 2018

4. Korea Ministry of Government Legislation (1997) Korean Laws in English - Toxic Chemicals Control Act. http://www.moleg.go.kr/english/ korLawEng?pstSeq=47535. Accessed 4 Jan 2018

5. Organisation for Economic Co-operation and Development (OECD) (2012) Test No. 305: Bioaccumulation in fish: aqueous and dietary exposure. OECD Guidel. Test. Chem. Paris

6. Petosa AR, Jaisi DP, Quevedo IR, Elimelech M, Tufenkji N (2010) Aggregation and deposition of engineered nanomaterials in aquatic
} 
environments: role of physicochemical interactions. Environ Sci Technol 44(17):6532-6549

7. Amiano I, Olabarrieta J, Vitorica J, Zorita S (2012) Acute toxicity of nanosized $\mathrm{TiO}_{2}$ to Daphnia magna under UVA irradiation. Environ Toxicol Chem 31(11):2564-2566. https://doi.org/10.1002/etc.1981

8. Ma H, Brennan A, Diamond SA (2012) Phototoxicity of $\mathrm{TiO}_{2}$ nanoparticles under solar radiation to two aquatic species: Daphnia magna and Japanese medaka. Environ Toxicol Chem 31(7):1621-1629. https://doi. org/10.1002/etc.1858

9. Sun H, Zhang X, Niu Q, Chen Y, Crittenden JC (2007) Enhanced accumulation of arsenate in carp in the presence of titanium dioxide nanoparticles. Water Air Soil Pollut 178(1-4):245-254. https://doi.org/10.1007/ s11270-006-9194-y

10. Zhang X, Sun H, Zhang Z, Niu Q, Chen Y, Crittenden JC (2007) Enhanced bioaccumulation of cadmium in carp in the presence of titanium dioxide nanoparticles. Chemosphere 67(1):160-166. https://doi. org/10.1016/J.CHEMOSPHERE.2006.09.003

11. Ferry JL et al (2009) Transfer of gold nanoparticles from the water column to the estuarine food web. Nat Nanotechnol 4(7):441-444. https:// doi.org/10.1038/nnano.2009.157

12. Griffitt RJ, Hyndman K, Denslow ND, Barber DS (2008) Comparison of molecular and histological changes in zebrafish gills exposed to metallic nanoparticles. Toxicol Sci 107(2):404-415. https://doi.org/10.1093/ toxsci/kfn256

13. Sun H, Zhang X, Zhang Z, Chen Y, Crittenden JC (2009) Influence of titanium dioxide nanoparticles on speciation and bioavailability of arsenite. Environ Pollut 157(4):1165-1170. https://doi.org/10.1016/j. envpol.2008.08.022

14. Johnston BD et al (2010) Bioavailability of nanoscale metal oxides TiO $\mathrm{CeO}_{2}$, and $\mathrm{ZnO}$ to fish. Environ Sci Technol 44(3):1144-1151. https://doi. org/10.1021/es901971a

15. Scown TM et al (2010) Effects of aqueous exposure to silver nanoparticles of different sizes in rainbow trout. Toxicol Sci 115(2):521-534. https ://doi.org/10.1093/toxsci/kfq076

16. Shaw BJ, Al-Bairuty G, Handy RD (2012) Effects of waterborne copper nanoparticles and copper sulphate on rainbow trout, (Oncorhynchus mykiss): physiology and accumulation. Aquat Toxicol 116-117:90-101. https://doi.org/10.1016/j.aquatox.2012.02.032

17. Zeumer R, Hermsen L, Kaegi R, Kühr S, Knopf B, Schlechtriem C (2020) Bioavailability of silver from wastewater and planktonic food borne silver nanoparticles in the rainbow trout Oncorhynchus mykiss. Sci Total Environ 706:135695. https://doi.org/10.1016/JSCITOTENV.2019.135695

18. Zeumer R et al (2020) Chronic effects of wastewater-borne silver and titanium dioxide nanoparticles on the rainbow trout (Oncorhynchus mykiss). Sci Total Environ 723:137974. https://doi.org/10.1016/j.scito tenv.2020.137974

19. Hou WC, Westerhoff P, Posner JD (2013) Biological accumulation of engineered nanomaterials: A review of current knowledge. Environ Sci: Processes Impacts 15:103-122. https://doi.org/10.1039/c2em30686g.

20. Kühnel D, Nickel C (2014) The OECD expert meeting on ecotoxicology and environmental fate-towards the development of improved OECD guidelines for the testing of nanomaterials. Sci Total Environ 472:347-353. https://doi.org/10.1016/J.SCITOTENV.2013.11.055

21. Aschberger K, Micheletti C, Sokull-Klüttgen B, Christensen FM (2011) Analysis of currently available data for characterising the risk of engineered nanomaterials to the environment and human health-lessons learned from four case studies. Environ Int 37(6):1143-1156. https://doi. org/10.1016/J.ENVINT.2011.02.005

22. ECHA (2011) Guidance on information requirements and chemical safety assessment. Eur Chem Agency. https://echa.europa.eu/ documents/10162/13643/information_requirements_r5_en.pdf/51ffb 7a7-baef-43ef-bac7-501e95b5a1d5. Accessed 2 Jan 2018

23. American Society for Testing and Materials (2003) ASTM E1022 94(2013) Standard guide for conducting bioconcentration tests with fishes and saltwater bivalve mollusks. https://www.arpae.it/cms3/ documenti/_cerca_doc/ecotossicologia/ASTM_E_1022_bioconcent razione.pdf. Accessed 4 Jan 2018

24. de WolfW et al (2007) Animal use replacement, reduction, and refinement: development of an integrated testing strategy for bioconcentration of chemicals in fish. Integr Environ Assess Manag 3(1):3-17. https://doi.org/10.1897/1551-3793(2007)3[3:AURRAR]2.0.CO;2
25. Russell WMS, Burch RL, Hume CW (1959) The principles of humane experimental technique, vol 238. Methuen, London

26. Guhad F (2005) Introduction to the 3Rs (refinement, reduction and replacement). J Am Assoc Lab Anim Sci 44(2):58-59. http://www. ingentaconnect.com/content/aalas/jaalas/2005/00000044/00000 002/art00012. Accessed 6 Dec 2017

27. Tannenbaum J, Bennett BT (2018) Russell and Burch's $3 R s$ then and now: The need for clarity in definition and purpose. J Am Assoc Lab Anim Sci 54(2):120-132. http://www.ingentaconnect.com/content/ aalas/jaalas/2015/00000054/00000002/art00002\#. Accessed 4 Jan 2018

28. Council of the European Union (EC) (1986) Council Directive 86/609/ EEC of 24 November 1986 on the approximation of laws, regulations and administrative provisions of the Member States regarding the protection of animal used for experimental and other scientific purposes.Official Journal L. pp 1-28. http://eur-lex.europa.eu/legal -content/EN/TXT/PDF/?uri=CELEX:31986LO609\&from=EN. Accessed 6 Dec 2017

29. European Union (2010) Directive 2010/63/EU of the European Parliament and of the Council of 22 September 2010 on the protection of animals used for scientific purposes. Off J Eur Union, pp. 33-79

30. Handy RD, Ahtiainen J, Navas JM, Goss G, Bleeker EAJ, von der Kammer F (2018) Proposal for a tiered dietary bioaccumulation testing strategy for engineered nanomaterials using fish. Environ Sci Nano 5(9):2030-2046. https://doi.org/10.1039/C7EN01139C

31. Baker TJ, Tyler CR, Galloway TS (2014) Impacts of metal and metal oxide nanoparticles on marine organisms. Environ Pollut 186:257271. https://doi.org/10.1016/J.ENVPOL.2013.11.014

32. Khan FR et al (2012) Bioaccumulation dynamics and modeling in an estuarine invertebrate following aqueous exposure to nanosized and dissolved silver. Environ Sci Technol 46(14):7621-7628. https://doi. org/10.1021/es301253s

33. Petersen EJ et al (2019) Strategies for robust and accurate experimental approaches to quantify nanomaterial bioaccumulation across a broad range of organisms. Environ Sci Nano 6(6):1619-1656. https ://doi.org/10.1039/C8EN01378K

34. Hartmann NIB, Skjolding LM, Hansen SF, Baun A, Kjølholt J, Gottschalk F (2014) Environmental fate and behaviour of nanomaterials: new knowledge on important transformation processes

35. Quik JTK, Velzeboer I, Wouterse M, Koelmans AA, Van de Meent D (2014) Heteroaggregation and sedimentation rates for nanomaterials in natural waters. Water Res 48:269-279

36. McCarty LS, Mackay D (1993) Enhancing ecotoxicological modeling and assessment. Body residues and modes of toxic action. Environ Sci Technol 27(9):1718-1728

37. Hickie BE, McCarty LS, Dixon GD (1995) A residue-based toxicokinetic model for pulse-exposure toxicity in aquatic systems. Environ Toxicol Chem 14(12):2187-2197

38. Sheppard S, Bembridge JD, Holmstrup M (1998) Advances in earthworm ecotoxicology: proceedings from the second international workshop on earthworm ecotoxicology, April 1997, Amsterdam, the Netherlands. SETAC Foundation for Environmental Toxicology and Chemistry

39. Fay AA, Brownawell BJ, Elskus AA, McElroy AE (2000) Critical body residues in the marine amphipod Ampelisca abdita: Sediment exposures with nonionic organic contaminants. Environ Toxicol Chem 19(4):1028-1035

40. Perceval O, Couillard Y, Pinel-Alloul B, Bonneris E, Campbell PGC (2006) Long-term trends in accumulated metals ( $\mathrm{Cd}, \mathrm{Cu}$ and $\mathrm{Zn}$ ) and metallothionein in bivalves from lakes within a smelter-impacted region. Sci Total Environ 369(1-3):403-418. https://doi.org/10.1016/j. scitotenv.2006.04.019

41. Verbost PM, Flik G, Lock RA, Wendelaar Bonga SE (1987) Cadmium inhibition of $\mathrm{Ca}^{2+}$ uptake in rainbow trout gills. Am J Physiol Integr Comp Physiol 253(2): R216-R221

42. Hogstrand C, Verbost PM, Bonga SE, Wood CM (1996) Mechanisms of zinc uptake in gills of freshwater rainbow trout: interplay with calcium transport. Am J Physiol Integr Comp Physiol 270(5):R1141-R1147

43. Bury NR, Wood CM (1999) Mechanism of branchial apical silver uptake by rainbow trout is via the proton-coupled $\mathrm{Na}^{+}$channel. Am J Physiol 
Integr Comp Physiol 277(5):R1385-R1391. https://doi.org/10.1152/ajpre gu.1999.277.5.R1385

44. Grosell M, Wood CM (2002) Copper uptake across rainbow trout gills: mechanisms of apical entry. J Exp Biol 205(8):1179-1188

45. Petris MJ (2004) The SLC31 (Ctr) copper transporter family. Pflügers Arch 447(5):752-755

46. Petros RA, DeSimone JM (2010) Strategies in the design of nanoparticles for therapeutic applications. Nat Rev Drug Discov 9(8):615-627

47. Ah CS, Han HS, Kim K, Jang D-J (2000) Phototransformation of alkanethiol-derivatized noble metal nanoparticle. Pure Appl Chem 72(1-2):91-99

48. Yin Y et al (2015) Water chemistry controlled aggregation and phototransformation of silver nanoparticles in environmental waters. J Environ Sci 34:116-125

49. Zheng Q, Zhou M, Deng W, Le XC (2015) Is there a silver lining? Aggregation and photo-transformation of silver nanoparticles in environmental waters. J Environ Sci 34:259-262

50. Navarro E et al (2008) Toxicity of silver nanoparticles to Chlamydomonas reinhardtii. Environ Sci Technol 42(23):8959-8964. https://doi. org/10.1021/es801785m

51. Liu J, Hurt RH (2010) lon release kinetics and particle persistence in aqueous nano-silver colloids. Environ Sci Technol 44(6):2169-2175. https://doi.org/10.1021/es9035557

52. Loza K et al (2014) The dissolution and biological effects of silver nanoparticles in biological media. J Mater Chem B 2(12):1634-1643

53. McLeod PB, Luoma SN, Luthy RG (2008) Biodynamic modeling of PCB uptake by Macoma balthica and Corbicula fluminea from sediment amended with activated carbon. Environ Sci Technol 42(2):484-490. https://doi.org/10.1021/es070139a

54. Morton B (1983) Feeding and digestion in Bivalvia. In: Saleuddin A, Wilbur KM (eds) The Mollusca. Physiology, Part 2, vol 5, Academic Press, New York, pp 65-147

55. Hakenkamp CC, Ribblett SG, Palmer MA, Swan CM, Reid JW, Goodison MR (2001) The impact of an introduced bivalve (Corbicula fluminea) on the benthos of a sandy stream. Freshw Biol 46(4):491-501

56. Nichols SJ, Silverman H, Dietz TH, Lynn JW, Garling DL (2005) Pathways of food uptake in native (Unionidae) and introduced (Corbiculidae and Dreissenidae) freshwater bivalves. J Great Lakes Res 31(1):87-96. https:// doi.org/10.1016/50380-1330(05)70240-9

57. Brendelberger H, Klauke C (2009) Pedal feeding in freshwater unionid mussels: particle-size selectivity. Int Vereinigung für Theor und Angew Limnol Verhandlungen 30(7):1082-1084

58. Hakenkamp CC, Palmer MA (1999) Introduced bivalves in freshwater ecosystems: the impact of Corbicula on organic matter dynamics in a sandy stream. Oecologia 119(3):445-451. https://doi.org/10.1007/s0044 20050806

59. Sprung M, Rose $U$ (1988) Influence of food size and food quantity on the feeding of the mussel Dreissena polymorpha. Oecologia 77(4):526532. https://doi.org/10.1007/BF00377269

60. Roditi HA, Strayer DL, Findlay SEG (1997) Characteristics of zebra mussel (Dreissena polymorpha) biodeposits in a tidal freshwater estuary. Arch für Hydrobiol 140(2):207-219

61. Basen T, Gergs R, Rothhaupt K-O, Martin-Creuzburg D (2012) Phytoplankton food quality effects on gammarids: benthic-pelagic coupling mediated by an invasive freshwater clam. Can J Fish Aquat Sci 70(2):198-207

62. Bruner KA, Fisher SW, Landrum PF (1994) The role of the zebra mussel, Dreissena polymorpha, in contaminant cycling: I. The effect of body size and lipid content on the bioconcentration of PCBs and PAHs. J Great Lakes Res 20(4):725-734. https://doi.org/10.1016/S0380-1330(94)71190 $-4$

63. Cantanhêde G, Hahn NS, Gubiani ÉA, Fugi R (2008) Invasive molluscs in the diet of Pterodoras granulosus (Valenciennes, 1821) (Pisces, Doradidae) in the upper Paraná River floodplain, Brazil. Ecol Freshw Fish 17(1):47-53. https://doi.org/10.1111/j.1600-0633.2007.00258.x

64. Gergs R, Rinke K, Rothhaupt K-O (2009) Zebra mussels mediate benthic-pelagic coupling by biodeposition and changing detrital stoichiometry. Freshw Biol 54(7):1379-1391. https://doi.org/10.111 1/j.1365-2427.2009.02188.x
65. Madenjian CP et al (2015) Changes in the Lake Michigan food web following dreissenid mussel invasions: a synthesis. J Great Lakes Res 41:217-231. https://doi.org/10.1016/J.JGLR.2015.08.009

66. Ricciardi A, Whoriskey FG, Rasmussen JB (1997) The role of the zebra mussel (Dreissena polymorpha) in structuring macroinvertebrate communities on hard substrata. Can J Fish Aquat Sci 54(11):2596-2608. https://doi.org/10.1139/f97-174

67. Nalepa TF, Hartson DJ, Fanslow DL, Lang GA, Lozano SJ (1998) Declines in benthic macroinvertebrate populations in southern Lake Michigan, 1980-1993. Can J Fish Aquat Sci 55(11):2402-2413

68. Morrison HA, Frank APC, Gobas, Lazar R, Whittle DM (1998) Projected changes to the trophodynamics of PCBs in the Western Lake Erie ecosystem attributed to the presence of zebra mussels (Dreissena polymorpha). Environ Sci Technol 32(24):3862-3867. https://doi.org/10.1021/ ES9804341

69. González MJ, Downing A (1999) Mechanisms underlying amphipod responses to zebra mussel (Dreissena polymorpha) invasion and implications for fish-amphipod interactions. Can J Fish Aquat Sci 56(4):679-685

70. Greenwood KS, Thorp JH, Summers RB, Guelda DL (2001) Effects of an exotic bivalve mollusc on benthic invertebrates and food quality in the Ohio River. Hydrobiologia 462(1/3):169-172. https://doi. org/10.1023/A:1013190301967

71. Lozano SJ, Scharold JV, Nalepa TF (2001) Recent declines in benthic macroinvertebrate densities in Lake Ontario. Can J Fish Aquat Sci 58(3):518-529

72. Strayer DL, Smith LC (2001) The zoobenthos of the freshwater tidal Hudson River and its response to the zebra mussel (Dreissena polymorpha) invasion. Arch für Hydrobiol Suppl Monogr Beiträge 139(1):1-52

73. Sylvester F, Boltovskoy D, Cataldo D (2007) The invasive bivalve Limnoperna fortunei enhances benthic invertebrate densities in South American floodplain rivers. Hydrobiologia 589(1):15-27. https://doi. org/10.1007/s10750-007-0708-4

74. Doherty FG (1988) The Asiatic clam, Corbicula spp., as a biological monitor in freshwater environments. Environ Monit Assess 15(2):143-181. https://doi.org/10.1007/bf00398912

75. Otchere FA (2005) Organochlorines (PCBs and pesticides) in the bivalves Anadara (Senilis) senilis, Crassostrea tulipa and Perna perna from the lagoons of Ghana. Sci Total Environ 348(1-3):102-114. https://doi. org/10.1016/j.scitotenv.2004.12.069

76. Berny P, Lachaux O, Buronfosse T, Mazallon M, Gillet C (2002) Zebra mussels (Dreissena polymorpha) as indicators of freshwater contamination with lindane. Environ Res 90(2):142-151. https://doi.org/10.1006/ enrs.2002.4371

77. Hayashi O, Kameshiro M, Masuda M, Satoh K (2008) Bioaccumulation and metabolism of $\left[{ }^{14} \mathrm{C}\right] \mathrm{Bisphenol} \mathrm{A}$ in the brackish water bivalve Corbicula japonica. Biosci Biotechnol Biochem 72(12):3219-3224. https ://doi.org/10.1271/bbb.80448

78. Jacomini AE, Avelar WEP, Martinêz AS, Bonato PS (2006) Bioaccumulation of atrazine in freshwater bivalves Anodontites trapesialis (Lamarck, 1819) and Corbicula fluminea (Müller, 1774). Arch Environ Contam Toxicol 51(3):387-391. https://doi.org/10.1007/s00244-005-0238-x

79. Regoli F, Orlando E (1994) Accumulation and subcellular distribution of metals ( $\mathrm{Cu}, \mathrm{Fe}, \mathrm{Mn}, \mathrm{Pb}$ and $\mathrm{Zn}$ ) in the Mediterranean mussel Mytilus galloprovincialis during a field transplant experiment. Mar Pollut Bull 28(10):592-600. https://doi.org/10.1016/0025-326X(94)90360-3

80. Vidal M-L, Bassères A, Narbonne J-F (2001) Potential biomarkers of trichloroethylene and toluene exposure in Corbicula fluminea. Environ Toxicol Pharmacol 9(3):87-97. https://doi.org/10.1016/S1382 $-6689(00) 00068-5$

81. Geret F, Serafim A, Bebianno MJ (2003) Antioxidant enzyme activities, metallothioneins and lipid peroxidation as biomarkers in Ruditapes decussatus? Ecotoxicology 12(5):417-426. https://doi. org/10.1023/A:1026108306755

82. Baudrimont $\mathrm{M}$ et al (1999) Field transplantation of the freshwater bivalve Corbicula fluminea along a polymetallic contamination gradient (river Lot, France): II. Metallothionein response to metal exposure. Environ Toxicol Chem 18(11):2472-2477. https://doi.org/10.1002/etc.56201 81113

83. Legeay A, Achard-Joris M, Baudrimont M, Massabuau J-C, Bourdineaud J-P (2005) Impact of cadmium contamination and oxygenation levels 
on biochemical responses in the Asiatic clam Corbicula fluminea. Aquat Toxicol 74:242-253. https://doi.org/10.1016/j.aquatox.2005.05.015

84. Marie V, Baudrimont M, Boudou A (2006) Cadmium and zinc bioaccumulation and metallothionein response in two freshwater bivalves (Corbicula fluminea and Dreissena polymorpha) transplanted along a polymetallic gradient. Chemosphere 65(4):609-617. https://doi. org/10.1016/j.chemosphere.2006.01.074

85. Hardivillier Y, Denis F, Demattei M-V, Bustamante P, Laulier M, Cosson R (2006) Metal influence on metallothionein synthesis in the hydrothermal vent mussel Bathymodiolus thermophilus. Comp Biochem Physiol Part C Toxicol Pharmacol 143(3):321-332. https://doi.org/10.1016/J. CBPC.2006.03.006

86. Marie V, Gonzalez P, Baudrimont M, Bourdineaud J-P, Boudou A (2006) Metallothionein response to cadmium and zinc exposures compared in two freshwater bivalves, Dreissena polymorpha and Corbicula fluminea. Biometals 19(4):399-407. https://doi.org/10.1007/s10534-005-4064-4

87. Basack SB, Oneto ML, Verrengia Guerrero NR, Kesten EM (1997) Accumulation and elimination of pentachlorophenol in the freshwater bivalve Corbicula fluminea. Bull Environ Contam Toxicol 58(3):497-503. https://doi.org/10.1007/s001289900362

88. Narbonne JF, Djomo JE, Ribera D, Ferrier V, Garrigues P (1999) Accumulation kinetics of polycyclic aromatic hydrocarbons adsorbed to sediment by the mollusk Corbicula fluminea. Ecotoxicol Environ Saf 42(1):1-8. https://doi.org/10.1006/eesa.1998.1701

89. Arini A, Pierron F, Mornet S, Baudrimont M (2020) Bioaccumulation dynamics and gene regulation in a freshwater bivalve after aqueous and dietary exposures to gold nanoparticles and ionic gold. Environ Sci Pollut Res 27(4):3637-3650. https://doi.org/10.1007/s1 1356-018-4009-4

90. Edwards DD, Vidrine MF (1994) A new species in the water mite subgenus Parasitatax (Acari: Unionicolidae: Unionicola) from the North American freshwater mussel, Utterbackia imbecillis (Bivalvia: Unionidae), J Elisha Mitchell Sci Soc 2:1-6

91. Graczyk T, Conn D, Marcogliese D, Graczyk H, de Lafontaine Y (2003) Accumulation of human waterborne parasites by zebra mussels (Dreissena polymorpha) and Asian freshwater clams (Corbicula fluminea). Parasitol Res 89(2):107-112

92. Wen C, Nie P, Zhu Z (2006) Population dynamics of the water mite Unionicola arcuata (Unionicolidae) in the freshwater bivalve Cristaria plicata (Unionidae) in Poyang Lake, eastern China. Dis Aquat Organ 70(1-2):123-127

93. Nagai K, Honjo T, Go J, Yamashita H, Oh SJ (2006) Detecting the shellfish killer Heterocapsa circularisquama (Dinophyceae) by measuring bivalve valve activity with a Hall element sensor. Aquaculture 255(1-4):395-401

94. Grizzle JM, Brunner CJ (2009) Infectious diseases of freshwater mussels and other freshwater bivalve mollusks. Rev Fish Sci 17(4):425-467

95. Verrengia Guerrero NR et al (2002) Evidence of differences in the biotransformation of organic contaminants in three species of freshwater invertebrates. Environ Pollut 117(3):523-530. https://doi.org/10.1016/ S0269-7491(01)00132-4

96. Calabrese A, Maclnnes JR, Nelson DA, Greig RA, Yevich PP (1984) Effects of long-term exposure to silver or copper on growth, bioaccumulation and histopathology in the blue mussel Mytilus edulis. Mar Environ Res 11(4):253-274. https://doi.org/10.1016/0141-1136(84)90038-2

97. Nichols SJ (1992) Maintenance of the zebra mussel (Dreissena polymorpha) under laboratory conditions. Nalepa TF, Schloesser DW (eds) Lewis Publishers, Boca Raton, FL

98. Kuehr S et al (2020) Testing the bioaccumulation of manufactured nanomaterials in the freshwater bivalve Corbicula fluminea using a new test method. Environ Sci Nano 7(2):535-553. https://doi.org/10.1039/ C9EN01112A

99. Loosanoff VL, Davis HC (1963) Rearing of Bivalve Mollusks. In: Russell FS (ed) Advances in Marine Biology. Academic Press, New York, pp 1-136

100. Heller J (1993) Hermaphroditism in molluscs. Biol J Linn Soc 48(1):19-42

101. Wächtler K, Dreher-Mansur MC, Richter T (2001) Larval types and early postlarval biology in naiads (Unionoida). In: Ecology and evolution of the freshwater mussels Unionoida. Springer, New York, pp 93-125

102. Thorp JH, Covich AP (2009) Ecology and classification of North American freshwater invertebrates. Academic Press, New York

103. Winter S (1996) Cadmium uptake kinetics by freshwater mollusc soft body under hard and soft water conditions. Chemosphere 32(10):19371948. https://doi.org/10.1016/0045-6535(96)00101-4
104. Luten JB, Bouquet W, Burggraaf MM, Rus J (1986) Accumulation, elimination, and speciation of cadmium and zinc in mussels Mytilus edulis, in the natural environment. Bull Environ Contam Toxicol 37(1):579-586. https://doi.org/10.1007/BF01607807

105. Wang WX, Fisher NS, Luoma SN (1996) Kinetic determinations of traceelement bioaccumulation in the mussel Mytilus edulis. Mar Ecol Ser 140(1-3):91-113. https://doi.org/10.3354/meps 140091

106. Andersen V, Maage A, Johannessen PJ (1996) Heavy metals in blue mussels (Mytilus edulis) in the Bergen Harbor area, western Norway. Bull Environ Contam Toxicol 57(4):589-596

107. Montes MO, Hanna SK, Lenihan HS, Keller AA (2012) Uptake, accumulation, and biotransformation of metal oxide nanoparticles by a marine suspension-feeder. J Hazard Mater 225-226:139-145. https://doi. org/10.1016/J.JHAZMAT.2012.05.009

108. Gomes T, Pereira CG, Cardoso C, Pinheiro JP, Cancio I, Bebianno MJ (2012) Accumulation and toxicity of copper oxide nanoparticles in the digestive gland of Mytilus galloprovincialis. Aquat Toxicol 118-119:7279. https://doi.org/10.1016/J.AQUATOX.2012.03.017

109. Renault S, Baudrimont M, Mesmer-Dudons N, Gonzalez P, Mornet S, Brisson A (2008) Impacts of gold nanoparticle exposure on two freshwater species: a phytoplanktonic alga (Scenedesmus subspicatus) and a benthic bivalve (Corbicula fluminea). Gold Bull 41(2):116-126. https:// doi.org/10.1007/BF03216589

110. Pan J-F et al (2012) Size dependent bioaccumulation and ecotoxicity of gold nanoparticles in an endobenthic invertebrate: The Tellinid clam Scrobicularia plana. Environ Pollut 168:37-43. https://doi.org/10.1016/J. ENVPOL.2012.03.051

111. Araújo R, Moreno D, Ramos M (1993) The Asiatic clam Corbicula fluminea (Müller, 1774) (Bivalvia: Corbiculidae) in Europe. Am Malacolog Bull 10(1)

112. McMahon RF (1999) Invasive characteristics of the freshwater bivalve Corbicula fluminea. Lewis Publishers, Boca Raton, Florida, pp 315-343

113. Phelps HL (1994) The Asiatic clam (Corbicula fluminea) invasion and system-level ecological change in the Potomac River Estuary near Washington, D C. Estuaries 17(3):614. https://doi.org/10.2307/1352409

114. Rajagopal S, van der Gelde G, Vaate A (2000) Reproductive biology of the Asiatic clams Corbicula fluminalis and Corbicula fluminea in the river Rhine. Fundam Appl Limnol 149(3):403-420. https://doi.org/10.1127/ archiv-hydrobiol/149/2000/403

115. Byrne M, Phelps H, Church T, Adair V, Selvakumaraswamy P, Potts J (2000) Reproduction and development of the freshwater clam Corbicula australis in southeast Australia. Hydrobiologia 418(1):185-197. https://doi.org/10.1023/a:1003986512832

116. Sousa R, Rufino M, Gaspar M, Antunes C, Guilhermino L (2008) Abiotic impacts on spatial and temporal distribution of Corbicula fluminea (Müller, 1774) in the River Minho estuary, Portugal. Aquat Conserv Mar Freshw Ecosyst 18(1):98-110. https://doi.org/10.1002/aqc.838

117. Griffiths RW, Schloesser DW, Leach JH, Kovalak WP (1991) Distribution and dispersal of the zebra mussel (Dreissena polymorpha) in the Great Lakes region. Can J Fish Aquat Sci 48(8):1381-1388

118. Karatayev AY, Burlakova LE, Padilla DK (2005) Contrasting distribution and impacts of two freshwater exotic suspension feeders, Dreissena polymorpha and Corbicula fluminea. In: The comparative roles of suspension-feeders in ecosystems. Springer, New York, pp 239-262

119. McMahon RF (2002) Evolutionary and physiological adaptations of aquatic invasive animals: $r$ selection versus resistance. Can J Fish Aquat Sci 59(7):1235-1244

120. Sousa R, Guilhermino L, Antunes C (2005) Molluscan fauna in the freshwater tidal area of the River Minho estuary, NW of Iberian Peninsula. Ann Limnol Int J Limnol 41(2):141-147. https://doi.org/10.1051/ $\operatorname{limn} / 2005009$

121. Stanley JK, Coleman JG, Weiss CA, Steevens JA (2010) Sediment toxicity and bioaccumulation of nano and micron-sized aluminum oxide. Environ Toxicol Chem 29(2):422-429. https://doi.org/10.1002/etc.52

122. Hull MS et al (2011) Filter-feeding bivalves store and biodeposit colloidally stable gold nanoparticles. Environ Sci Technol 45(15):6592-6599. https://doi.org/10.1021/es200809c

123. Bourgeault $\mathrm{A}$ et al (2015) The challenge of studying $\mathrm{TiO}_{2}$ nanoparticle bioaccumulation at environmental concentrations: crucial use of a stable isotope tracer. Environ Sci Technol 49(4):2451-2459 
124. Reeders HH, De Vaate AB, Slim FJ (1989) The fitration rate of Dreissena polymorpha (Bivalvia) in three Dutch lakes with reference to biological water quality management. Freshw Biol 22(1):133-141. https:// doi.org/10.1111/j.1365-2427.1989.tb01088.x

125. Gilek M, Bjork M, Broman D (1998) The role of the blue mussel, Mytilus edulis, in the cycling of hydrophobic organic contaminants in the baltic proper. Oceanogr Lit Rev 1(45):132

126. Riisgård HU, Møhlenberg F (1979) An improved automatic recording apparatus for determining the filtration rate of Mytilus edulis as a function of size and algal concentration. Mar Biol 52(1):61-67

127. Fisher SW, Hwang H, Atanasoff M, Landrum PF (1999) Lethal body residues for pentachlorophenol in zebra mussels (Dreissena polymorpha) under varying conditions of temperature and $\mathrm{pH}$. Ecotoxicol Environ Saf 43(3):274-283. https://doi.org/10.1006/eesa.1999.1789

128. Riisgård HU, Kittner C, Seerup DF (2003) Regulation of opening state and filtration rate in filter-feeding bivalves (Cardium edule, Mytilus edulis, Mya arenaria) in response to low algal concentration. J Exp Mar Bio Ecol 284:105-127

129. Rodgers J, Cherry D, Graney R, Dickson K, Cairns J (1980) Comparison of heavy metal interactions in acute and artificial stream bioassay techniques for the Asiatic clam. In: Aquatic Toxicology. Eaton J, Parrish P, Hendricks A (eds) ASTM International, pp 266-280. https://doi. org/10.1520/STP27424S

130. Doherty FG, Cherry DS, Cairns J (1987) Valve closure responses of the Asiatic clam Corbicula fluminea exposed to cadmium and zinc. Hydrobiologia 153:159-167

131. Wildridge PJ, Werner RG, Doherty FG, Neuhauser EF (1998) Acute effects of potassium on filtration rates of adult zebra mussels, Dreissena polymorpha. J Great Lakes Res 24(3):629-636. https://doi. org/10.1016/S0380-1330(98)70850-0

132. Kádár E, Salánki J, Jugdaohsingh R, Powell JJ, McCrohan CR, White KN (2001) Avoidance responses to aluminium in the freshwater bivalve Anodonta cygnea. Aquat Toxicol 55(3-4):137-148. https://doi. org/10.1016/S0166-445X(01)00183-7

133. Fournier E, Tran D, Denison F, Massabuau J-C (2004) Valve closure response to uranium exposure for a freshwater bivalve (Corbicula fluminea): quantification of the influence of $\mathrm{pH}$. Environ Toxicol Chem 23(5):1108-1114

134. Vijayavel K, Gopalakrishnan S, Balasubramanian MP (2007) Sublethal effect of silver and chromium in the green mussel Perna viridis with reference to alterations in oxygen uptake, filtration rate and membrane bound ATPase system as biomarkers. Chemosphere 69(6):979-986. https://doi.org/10.1016/J.CHEMOSPHERE.2007.05.011

135. Uno S, Shiraishi H, Hatakeyama S, Otsuki A, Koyama J (2001) Accumulative characteristics of pesticide residues in organs of bivalves (Anodonta woodiana and Corbicula leana) under natural conditions. Arch Environ Contam Toxicol 40(1):35-47. https://doi.org/10.1007/ s002440010146

136. Schmidt B et al (2011) Quantitative characterization of gold nanoparticles by field-flow fractionation coupled online with light scattering detection and inductively coupled plasma mass spectrometry. Anal Chem 83(7):2461-2468. https://doi.org/10.1021/ac102545e

137. Loeschner K et al (2013) Detection and characterization of silver nanoparticles in chicken meat by asymmetric flow field flow fractionation with detection by conventional or single particle ICP-MS. Anal Bioanal Chem 405(25):8185-8195. https://doi.org/10.1007/ s00216-013-7228-z

138. Covich AP (1977) How do crayfish respond to plants and mollusca as alternate food resources. Freshw crayfish 3:165-179

139. Lodge DM et al (1987) Distribution of freshwater snails: spatial scale and the relative importance of physicochemical and biotic factors. Am Malacol Bull 5(1):73-84

140. Brown KM, Strouse BH (1988) Relative vulnerability of six freshwater gastropods to the leech Nephelopsis obscura (Verrill). Freshw Biol 19(2):157-165

141. Kesler DH, Munns WR Jr (1989) Predation by Belostoma flumineum (Hemiptera): an important cause of mortality in freshwater snails. J North Am Benthol Soc 8(4):342-350

142. Osenberg CW (1989) Resource limitation, competition and the influence of life history in a freshwater snail community. Oecologia 79(4):512-519
143. Hunter RD (1980) Effects of grazing on the quantity and quality of freshwater Aufwuchs. Hydrobiologia 69(3):251-259

144. Sheldon SP (1987) The effects of herbivorous snails on submerged macrophyte communities in Minnesota lakes. Ecology 68(6):1920-1931

145. Steinman AD, McIntire CD, Lowry RR (1987) Effects of herbivore type and density on chemical composition of algal assemblages in laboratory streams. J North Am Benthol Soc 6(3):189-197

146. Lowe RL, Hunter RD (1988) Effect of grazing by Physa integra on periphyton community structure. J North Am Benthol Soc 7(1):29-36

147. McCormick PV, Stevenson RJ (1989) Effects of snail grazing on benthic algal community structure in different nutrient environments. J North Am Benthol Soc 8(2):162-172

148. Swamikannu X, Hoagland KD (1989) Effects of snail grazing on the diversity and structure of a periphyton community in a eutrophic pond. Can J Fish Aquat Sci 46(10):1698-1704

149. Tashiro JS, Colman SD (1982) Filter-feeding in the freshwater prosobranch snail Bithynia tentaculata: bioenergetic partitioning of ingested carbon and nitrogen. Am Midl Nat 123:114-132

150. Tashiro JS (1982) Grazing in Bithynia tentaculata: age-specific bioenergetic patterns in reproductive partitioning of ingested carbon and nitrogen. Am Midl Nat 122:133-150

151. Brown KM, Lydeard C (2010) Mollusca: gastropoda. In: Thorp JH, Covich AP (eds) Ecology and classification of North American freshwater invertebrates. Elsevier, New York, pp 277-306

152. Aldridge DW (1983) Physiological ecology of freshwater prosobranchs. In: Ecology. Elsevier, New York, pp 329-358

153. Jones JD (1964) Respiratory gas exchange in the aquatic pulmonate, Biomphalaria sudanica. Comp Biochem Physiol 12(3):297-310. https:// doi.org/10.1016/0010-406X(64)90061-1

154. Legierse KCHM, Sijm DTHM, van Leeuwen CJ, Seinen W, Hermens JLM (1998) Bioconcentration kinetics of chlorobenzenes and the organophosphorus pesticide chlorthion in the pond snail Lymnaea stagnalis - a comparison with the guppy Poecilia reticulata. Aquat Toxicol 41(4):301-323. https://doi.org/10.1016/S0166-445X(97)00092-1

155. Meredith-Williams M, Carter L, Fussell R, Raffaelli D, Ashauer R, Boxall ABA (2012) Uptake and depuration of pharmaceuticals in aquatic invertebrates. Environ Pollut 165:250-258. https://doi.org/10.1016/j.envpol.2011.11.029

156. Holcombe GW, Phipps GL, Fiandt JT (1983) Toxicity of selected priority pollutants to various aquatic organisms. Ecotoxicol Environ Saf 7(4):400-409

157. Gonçalves SF et al (2017) Effects of silver nanoparticles on the freshwater snail Physa acuta: the role of test media and snails'life cycle stage. Environ Toxicol Chem 36(1):243-253

158. Oliveira-Filho E et al (2019) Effects of AgNPs on the snail Biomphalaria glabrata: Survival, reproduction and silver accumulation. Toxics 7(1):12. https://doi.org/10.3390/toxics7010012

159. Niederwanger $M$ et al (2017) Challenging the metallothionein (MT) gene of Biomphalaria glabrata: unexpected response patterns due to cadmium exposure and temperature stress. Int J Mol Sci 18(8):1747

160. Phillips DJH, Rainbow PS (1989) Strategies of trace metal sequestration in aquatic organisms. Mar Environ Res 28(1-4):207-210

161. Roesijadi G (1992) Metallothioneins in metal regulation and toxicity in aquatic animals. Aquat Toxicol 22(2):81-113. https://doi. org/10.1016/0166-445X(92)90026-J

162. Dallinger R, Berger B, Hunziger P, Kgi JHR (1997) Metallothionein in snail Cd and Cu metabolism. Nature 388(6639):237-238

163. Bebianno MJ, Langston WJ (1998) Cadmium and metallothionein turnover in different tissues of the gastropod Littorina littorea. Talanta 46(2):301-313

164. English TE, Storey KB (2003) Freezing and anoxia stresses induce expression of metallothionein in the foot muscle and hepatopancreas of the marine gastropod Littorina littorea. J Exp Biol 206(14):2517-2524

165. Serafim A, Bebianno MJ (2010) Effect of a polymetallic mixture on metal accumulation and metallothionein response in the clam Ruditapes decussatus. Aquat Toxicol 99(3):370-378. https://doi.org/10.1016/J. AQUATOX.2010.05.016

166. Palacios Ò et al (2011) Shaping mechanisms of metal specificity in a family of metazoan metallothioneins: evolutionary differentiation of mollusc metallothioneins. BMC Biol 9(1):4

167. Pedrini-Martha V, Niederwanger M, Kopp R, Schnegg R, Dallinger R (2016) Physiological, diurnal and stress-related variability of 
cadmium-metallothionein gene expression in land snails. PLoS ONE $11: 3$

168. da Silva Cantinha R, Borrely SI, Oguiura N, de Bragança Pereira CA, Rigolon MM, Nakano E (2017) HSP70 expression in Biomphalaria glabrata snails exposed to cadmium. Ecotoxicol Environ Saf 140:18-23

169. Niederwanger $M$ et al (2017) Biomphalaria glabrata metallothionein: Lacking metal specificity of the protein and missing gene upregulation suggest metal sequestration by exchange instead of through selective binding. Int J Mol Sci 18(7):1457

170. Gonçalves SF et al (2016) Sub-lethal cadmium exposure increases phytochelatin concentrations in the aquatic snail Lymnaea stagnalis. Sci Total Environ 568:1054-1058

171. Desouky MMA (2006) Tissue distribution and subcellular localization of trace metals in the pond snail Lymnaea stagnalis with special reference to the role of lysosomal granules in metal sequestration. Aquat Toxicol 77(2):143-152. https://doi.org/10.1016/j.aquatox.2005.11.009

172. Russell-Hunter WD (1978) Ecology of freshwater pulmonates. In: Fretter V, Peake J (eds) Pulmonates. London, Academic Press, XI, Orlando, pp 335-383

173. McMahon RF (1983) Physiological ecology of freshwater pulmonates. In: Russell-Hunter WD (ed) The Mollusca, vol 6. Academic Press, Orlando, pp 359-430

174. Anderson RL, DeFoe DL (1980) Toxicity and bioaccumulation of endrin and methoxychlor in aquatic invertebrates and fish. Environ Pollut Ser A Ecol Biol 22(2):111-121. https://doi.org/10.1016/0143-1471(80)90187-7

175. Thybaud E, Caquet T (1991) Uptake and elimination of lindane by Lymnaea palustris (mollusca: Gastropoda): A pharmacokinetic approach. Ecotoxicol Environ Saf 21(3):365-376. https://doi. org/10.1016/0147-6513(91)90075-Z

176. Ramskov T et al (2014) Bioaccumulation and effects of different-shaped copper oxide nanoparticles in the deposit-feeding snail Potamopyrgus antipodarum. Environ Toxicol Chem 33(9):1976-1987. https://doi. org/10.1002/etc.2639

177. Bao S, Huang J, Liu X, Tang W, Fang T (2018) Tissue distribution of $\mathrm{Ag}$ and oxidative stress responses in the freshwater snail Bellamya aeruginosa exposed to sediment-associated Ag nanoparticles. Sci Total Environ 644:736-746. https://doi.org/10.1016/j.scitotenv.2018.07.011

178. Thomas JD, Lough AS, Lodge RW (1975) The chemical ecology of Biomphalaria glabrata (Say), the snail host of Schistosoma mansoni Sambon: the search for factors in media conditioned by snails which inhibit their growth and reproduction. J Appl Ecol 12(2):421-436. https://doi. org/10.2307/2402165

179. Brown DS (1978) Pulmonate molluscs as intermediate hosts for digenetic trematodes. In: Fretter V, Peake J (eds) Pulmonates, vol 2. Academic Press, New York, pp 287-333

180. Anderson RM, May RM (1979) Prevalence of schistosome infections within molluscan populations: observed patterns and theoretical predictions. Parasitology 79(1):63-94

181. Minchella DJ, Loverde PT (1981) A cost of increased early reproductive effort in the snail Biomphalaria glabrata. Am Nat 118(6):876-881

182. Holmes JC (1983) Evolutionary relationships between parasitic helminths and their hosts. In: Futuyma D, Slatkin M (eds) Coevolution. Sinauer Associates Inc, pp 161-185

183. Minchella DJ, Leathers BK, Brown KM, McNair JN (1985) Host and parasite counteradaptations: an example from a freshwater snail. Am Nat 126(6):843-854

184. Brown KM, Leathers BK, Minchella DJ (1988) Trematode prevalence and the population dynamics of freshwater pond snails. Am Midl Nat 120(2):289-301

185. Elangovan R, White KN, McCrohan CR (1997) Bioaccumulation of aluminium in the freshwater snail Lymnaea stagnalis at neutral $\mathrm{pH}$. Environ Pollut 96(1):29-33. https://doi.org/10.1016/S0269-7491(97)00009-2

186. Elangovan R, McCrohan CR, Ballance S, Powell JJ, White KN (2000) Localization and fate of aluminium in the digestive gland of the freshwater snail Lymnaea stagnalis. Tissue Cell 32(1):79-87. https://doi.org/10.1054/ tice.1999.0089

187. Croteau MN, Misra SK, Luoma SN, Valsami-Jones E (2011) Silver bioaccumulation dynamics in a freshwater invertebrate after aqueous and dietary exposures to nanosized and ionic Ag. Environ Sci Technol 45(15):6600-6607. https://doi.org/10.1021/es200880c
188. Ma T, Gong S, Tian B (2017) Effects of sediment-associated CuO nanoparticles on Cu bioaccumulation and oxidative stress responses in freshwater snail Bellamya aeruginosa. Sci Total Environ 580:797-804. https://doi.org/10.1016/j.scitotenv.2016.12.026

189. Van Duivenboden YA, Pieneman AW, Ter Maat A (1985) Multiple mating suppresses fecundity in the hermaphrodite freshwater snail Lymnaea stagnalis: a laboratory study. Anim Behav 33(4):1184-1191. https://doi. org/10.1016/S0003-3472(85)80179-2

190. USEPA, "Methods for measuring the acute toxicity of effluents and receiving waters to freshwater and marine organisms," United States Environ. Prot. Agency, Off. Water, Washingt., 2002.

191. Jokinen EH, Guerette J, Kortmann RW (1982) The natural history of an ovoviviparous snail, Viviparus georgianus (Lea), in a soft-water eutrophic lake. Freshw Invertebr Biol 1(4):2-17

192. DeFoe DL (1975) Multichannel toxicant injection system for flowthrough bioassays. J Fish Board Canada 32(4):544-546

193. Takimoto Y, Ohshima M, Miyamoto J (1987) Comparative metabolism of fenitrothion in aquatic organisms. Ecotoxicol Environ Saf 13(1):104-117. https://doi.org/10.1016/0147-6513(87)90048-0

194. Engel DW, Brouwer M (1984) Cadmium-binding proteins in the blue crab, Callinectes sapidus: laboratory-field comparison. Mar Environ Res 14(1-4):139-151. https://doi.org/10.1016/0141-1136(84)90075-8

195. Hudson ML, Costello DM, Daley JM, Burton GA (2019) Species-specific (Hyalella azteca and Lymnea stagnalis) dietary accumulation of gold nano-particles associated with periphyton. Bull Environ Contam Toxicol 103(2):255-260. https://doi.org/10.1007/s00128-019-02620-2

196. Coeurdassier M, De Vaufleury A, Badot P-M (2003) Bioconcentration of cadmium and toxic effects on life-history traits of pond snails (Lymnaea palustris and Lymnaea stagnalis) in laboratory bioassays. Arch Environ Contam Toxicol 45(1):102-109. https://doi.org/10.1007/s0024 4-002-0152-4

197. Nyman A-M, Schirmer K, Ashauer R (2014) Importance of toxicokinetics for interspecies variation in sensitivity to chemicals. Environ Sci Technol 48(10):5946-5954. https://doi.org/10.1021/es5005126

198. Moolman L, Van Vuren JHJ, Wepener V (2007) Comparative studies on the uptake and effects of cadmium and zinc on the cellular energy allocation of two freshwater gastropods. Ecotoxicol Environ Saf 68(3):443-450. https://doi.org/10.1016/J.ECOENV.2006.12.017

199. Croteau MN, Dybowska AD, Luoma SN, Valsami-Jones E (2011) A novel approach reveals that zinc oxide nanoparticles are bioavailable and toxic after dietary exposures. Nanotoxicology 5(1):79-90. https://doi. org/10.3109/17435390.2010.501914

200. Lalah JO et al (2003) The bioaccumulation and fate of a branched ${ }^{14} \mathrm{C}$-p-nonylphenol isomer in Lymnaea stagnalis L. Environ Toxicol Chem 22(7):1428-1436. https://doi.org/10.1002/etc.5620220703

201. Whitehead M, Powell JJ, Thompson RPH (1996) Regulation of metal absorption in the gastrointestinal tract. Gut 39:625-628

202. Conrad ME, Umbreit JN, Moore EG (1991) A role for mucin in the absorption of inorganic iron and other metal cations: a study in rats. Gastroenterology 100(1):129-136

203. Powell JJ, Thompson RPH (1993) The chemistry of aluminium in the gastrointestinal lumen and its uptake and absorption. Proc Nutr Soc 52(1):241-253. https://doi.org/10.1079/PNS19930056

204. Exley C, Wicks AJ, Hubert RB, Birchall DJ (1996) Kinetic constraints in acute aluminium toxicity in the rainbow trout (Oncorhynchus mykiss). J Theor Biol 179(1):25-31

205. Li H, Turner A, Brown MT (2013) Accumulation of aqueous and nanoparticulate silver by the marine gastropod Littorina littorea. Water, Air, Soil Pollut 224(1):1354. https://doi.org/10.1007/s11270-012-1354-7

206. Dybowska AD et al (2011) Synthesis of isotopically modified ZnO nanoparticles and their potential as nanotoxicity tracers. Environ Pollut 159(1):266-273. https://doi.org/10.1016/J.ENVPOL.2010.08.032

207. Moldovan M, Rauch S, Gómez M, Antonia Palacios M, Morrison GM (2001) Bioaccumulation of palladium, platinum and rhodium from urban particulates and sediments by the freshwater isopod Asellus aquaticus. Water Res 35(17):4175-4183. https://doi.org/10.1016/S0043 -1354(01)00136-1

208. Whitehurst IT (1991) The Gammarus: Asellus ratio as an index of organic pollution. Water Res 25(3):333-339 
209. Verovnik R, Sket B, Trontelj P (2005) The colonization of Europe by the freshwater crustacean Asellus aquaticus (Crustacea: Isopoda) proceeded from ancient refugia and was directed by habitat connectivity. Mol Ecol 14(14):4355-4369

210. De Lange HJ, Sperber V, Peeters ETHM (2006) Avoidance of polycyclic aromatic hydrocarbon-contaminated sediments by the freshwater invertebrates Gammarus pulex and Asellus aquaticus. Environ Toxicol Chem 25(2):452-457

211. Weltje L, Oehlmann J (2006) Effects of endocrine disrupting compounds and temperature on the moulting frequency of the freshwater isopod Asellus aquaticus L. (Isopoda: Asellota). Acta Biol Benrodis 13:105-115

212. Ekvall MT, Hedberg J, Odnevall Wallinder I, Hansson L-A, Cedervall T (2018) Long-term effects of tungsten carbide (WC) nanoparticles in pelagic and benthic aquatic ecosystems. Nanotoxicology 12(1):79-89

213. Fuller N, Ford AT, Nagorskaya LL, Gudkov DI, Smith JT (2018) Reproduction in the freshwater crustacean Asellus aquaticus along a gradient of radionuclide contamination at Chernobyl. Sci Total Environ 628:11-17

214. O'Callaghan I, Harrison S, Fitzpatrick D, Sullivan T (2019) The freshwater isopod Asellus aquaticus as a model biomonitor of environmental pollution: A review. Chemosphere 235:498-509. https://doi.org/10.1016/j. chemosphere.2019.06.217

215. Lockwood APM (1959) The osmotic and ionic regulation of Asellus aquaticus (L.). J Exp Biol 36(3):546-555

216. Lagerspetz K, Mattila M (1961) Salinity reactions of some fresh-and brackish-water crustaceans. Biol Bull 120(1):44-53

217. WolffWJ (1973) The distribution of Asellus aquaticus (L.) and Proasellus meridianus (Rac.) in the southwestern part of the Netherlands. Hydrobiologia 42(4):381-392

218. Moore JW (1975) The role of algae in the diet of Asellus aquaticus L. and Gammarus pulex L. J Anim Ecol 44(3):719-730

219. Rossi L, Fano AE (1979) Role of fungi in the trophic niche of the congeneric detritivorous Asellus aquaticus and A. coxalis (Isopoda). Oikos 32(3):380-385

220. Hargeby A (1990) Effects of pH, humic substances and animal interactions on survival and physiological status of Asellus aquaticus $\mathrm{L}$. and Gammarus pulex (L.). Oecologia 82(3):348-354. https://doi.org/10.1007/ bf00317482

221. Graça MAS, Maltby L, Calow P (1993) Importance of fungi in the diet of Gammarus pulex and Asellus aquaticus. Oecologia 96(3):304-309. https ://doi.org/10.1007/bf00317498

222. Graça MAS, Maltby L, Calow P (1994) Comparative ecology of Gammarus pulex (L.) and Asellus aquaticus (L.) I: population dynamics and microdistribution. Hydrobiologia 281(3):155-162. https://doi. org/10.1007/bf00028678

223. Hellawell JM (2012) Biological indicators of freshwater pollution and environmental management. Springer Science \& Business Media

224. Williams WD (1962) Notes on the ecological similarities of Asellus aquaticus (L.) and A. meridianus Rac. (Crust., Isopoda). Hydrobiologia 20(1):1-30. https://doi.org/10.1007/bf00038733

225. Marcus JH, Sutcliffe DW, Willoughby LG (1978) Feeding and growth of Asellus aquaticus (Isopoda) on food items from the littoral of Windermere, including green leaves of Elodea canadensis. Freshw Biol 8(6):505-519. https://doi.org/10.1111/j.1365-2427.1978.tb01473.x

226. Levanidov VJ (1949) Znachenie allohtonnogo materiala kak pichevogo resursa $v$ vodoeme na primere pitanij vodjnago oslika (Asellus aquaticus L.). Tr Vses Gidrobiol obch 1:100-117

227. Birstein JA (1951) Fauna USSR Freshwater Asellota. Moscow Acad. Sci, USSR

228. Holland GJ (1956) The eradication of Asellus aquaticus from water supply mains. J Inst Water Eng 10:220-241

229. Økland J, Økland KA (1986) The effects of acid deposition on benthic animals in lakes and streams. Experientia 42(5):471-486. https://doi. org/10.1007/bf01946685

230. Migliore L, de Nicola Giudici M (1990) Toxicity of heavy metals to Asellus aquaticus (L) (Crustacea, Isopoda). Hydrobiologia 203(3):155-164. https ://doi.org/10.1007/bf00005684

231. Van Hattum B, Korthals G, Van Straalen NM, Govers HAJ, Joosse ENG (1993) Accumulation patterns of trace metals in freshwater isopods in sediment bioassays - Influence of substrate characteristics, temperature and pH. Water Res 27(4):669-684. https:// doi.org/10.1016/0043-1354(93)90177-J

232. Elangovan R, Ballance S, White KN, McCrohan CR, Powell JJ (1999) Accumulation of aluminium by the freshwater crustacean Asellus aquaticus in neutral water. Environ Pollut 106(3):257-263. https://doi.org/10.1016/ S0269-7491(99)00117-7

233. Rauch S, Morrison GM (1999) Platinum uptake by the freshwater isopod Asellus aquaticus in urban rivers. Sci Total Environ 235(1-3):261-268. https://doi.org/10.1016/S0048-9697(99)00203-X

234. Berandah FE, Kong YC, Ismail A (2010) Bioaccumulation and distribution of heavy metals $(\mathrm{Cd}, \mathrm{Cu}, \mathrm{Fe}, \mathrm{Ni}, \mathrm{Pb}$ and $\mathrm{Zn})$ in the different tissues of Chicoreus capucinus lamarck (Mollusca: Muricidae) collected from Sungai Janggut, Kuala Langat, Malaysia. Env Asia 3(1):65-71

235. Hare L (1992) Aquatic insects and trace metals: bioavailability, bioaccumulation, and toxicity. Crit Rev Toxicol 22(5-6):327-369

236. Goodyear KL, McNeill S (1999) Bioaccumulation of heavy metals by aquatic macro-invertebrates of different feeding guilds: a review. Sci Total Environ 229(1-2):1-19. https://doi.org/10.1016/S0048 -9697(99)00051-0

237. Persson L (1983) Food consumption and competition between age classes in a perch Perca fluviatilis population in a shallow eutrophic lake. Oikos 82:197-207

238. Segner H, Back H (1985) Importance of contaminated food for the uptake of heavy metals in the rainbow trout, Salmo gairdneri. Naturwissenschaften 72(7):379-380

239. Rask M, Hiisivuori C (1985) The predation on Asellus aquaticus (L.) by perch, Perca fluviatilis (L.), in a small forest lake. Hydrobiologia 121(1):27-33. https://doi.org/10.1007/bf00035226

240. Verrell PA (1985) Predation and the evolution of precopula in the isopod Asellus aquaticus. Behaviour 95(3-4): 198-202

241. van Hattum $B$, de Voogt $P$, van den Bosch $L$, van Straalen NM, Joosse ENG, Govers H (1989) Bioaccumulation of cadmium by the freshwater isopod Asellus aquaticus (L.) from aqueous and dietary sources. Environ Pollut 62(2-3):129-151. https://doi.org/10.1016/0269-7491(89)90183-8

242. Dick JTA, Platvoet D, Kelly DW (2002) Predatory impact of the freshwater invader Dikerogammarus villosus (Crustacea: Amphipoda). Can J Fish Aquat Sci 59(6):1078-1084

243. Thybaud E, Le Bras S (1988) Absorption and elimination of lindane by Asellus aquaticus (Crustacea, Isopoda). Bull Environ Contam Toxicol 40(5):731-735. https://doi.org/10.1007/bf01697523

244. van Hattum B, CidMontañés JF (1999) Toxicokinetics and bioconcentration of polycyclic aromatic hydrocarbons in freshwater isopods. Environ Sci Technol 33(14):2409-2417. https://doi.org/10.1021/es9800479

245. Sures B, Taraschewski H (1995) Cadmium concentrations in two adult acanthocephalans, Pomphorhynchus laevis and Acanthocephalus lucii, as compared with their fish hosts and cadmium and lead levels in larvae of A. lucii as compared with their crustacean host. Parasitol Res 81(6):494-497

246. Hasu T, TellervoValtonen E, Jokela J (2006) Costs of parasite resistance for female survival and parental care in a freshwater isopod. Oikos 114(2):322-328

247. Plahuta M, Tišler T, Pintar A, Toman MJ (2015) Adverse effects of bisphenol A on water louse (Asellus aquaticus). Ecotoxicol Environ Saf 117:81-88. https://doi.org/10.1016/j.ecoenv.2015.03.031

248. McCahon CP, Pascoe D (1988) Culture techniques for three freshwater macroinvertebrate species and their use in toxicity tests. Chemosphere 17(12):2471-2480. https://doi.org/10.1016/0045-6535(88)90157-9

249. Richter S, Nagel R (2007) Bioconcentration, biomagnification and metabolism of ${ }^{14} \mathrm{C}$-terbutryn and ${ }^{14} \mathrm{C}$-benzo[a]pyrene in Gammarus fossarum and Asellus aquaticus. Chemosphere 66(4):603-610. https:// doi.org/10.1016/j.chemosphere.2006.08.002

250. Gross-Sorokin MY, Grist EPM, Cooke M, Crane M (2003) Uptake and depuration of 4-nonylphenol by the benthic invertebrate Gammarus pulex: How important is feeding rate? Environ Sci Technol 37(10):22362241. https://doi.org/10.1021/es020092n

251. Rubach MN, Ashauer R, Maund SJ, Baird DJ, Van den Brink PJ (2010) Toxicokinetic variation in 15 freshwater arthropod species exposed to the insecticide chlorpyrifos. Environ Toxicol Chem 29(10):2225-2234. https://doi.org/10.1002/etc.273

252. Peeters ETHM, De Jager TJ, Beijer JAJ, Koelmans AA (2000) Effects of benzo(a)pyrene and size of organic matter particles on 
bioaccumulation and growth of Asellus aquaticus. Arch Environ Contam Toxicol 39(3):307-314. https://doi.org/10.1007/s002440010109

253. Kampe S, Kaegi R, Schlich K, Wasmuth C, Hollert H, Schlechtriem C (2018) Silver nanoparticles in sewage sludge: bioavailability of sulfidized silver to the terrestrial Isopod Porcellio scaber. Environ Toxicol Chem. https://doi.org/10.1002/etc.4102

254. Brown BE (1977) Uptake of copper and lead by a metaltolerant isopod Asellus meridianus Rac. Freshw Biol 7(3):235-244. https://doi. org/10.1111/j.1365-2427.1977.tb01671.x

255. Eimers M, Evans R, Welbourn P (2001) Cadmium accumulation in the freshwater isopod Asellus racovitzai: the relative importance of solute and particulate sources at trace concentrations. Environ Pollut 111 (2):247-253. https://doi.org/10.1016/S0269-7491(00)00066-X

256. Croteau M-N, Luoma SN (2007) Characterizing dissolved Cu and Cd uptake in terms of the biotic ligand and biodynamics using enriched stable isotopes. Environ Sci Technol 41(9):3140-3145

257. Croteau M-N, Luoma SN, Pellet B (2007) Determining metal assimilation efficiency in aquatic invertebrates using enriched stable metal isotope tracers. Aquat Toxicol 83(2):116-125

258. Komjarova I, Blust $\mathrm{R}$ (2009) Effect of $\mathrm{Na}$, $\mathrm{Ca}$ and $\mathrm{pH}$ on simultaneous uptake of $\mathrm{Cd}, \mathrm{Cu}, \mathrm{Ni}, \mathrm{Pb}$, and $\mathrm{Zn}$ in the water flea Daphnia magna measured using stable isotopes. Aquat Toxicol 94(2):81-86. https://doi. org/10.1016/j.aquatox.2009.05.018

259. Macneil C, Dick JTA, Elwood RW (1997) The trophic ecology of freshwater Gammarus spp (Crustacea: Amphipoda): problems and perspectives concerning the functional feeding group concept. Biol Rev Cambridge Philos Soc 72:3

260. Jackson HHT (1909) A contribution to the natural history of the amphipod, Hyalella knickerbockeri (Bate). Bull Wisc Nat Hist Soc 34:49-60

261. Clemens HP (1950) Life cycle and ecology of Gammarus fasciatus Say. Ohio State University, Ohio

262. Wienert CC (1950) Biology of the Amphipoda of Michigan. University of Michigan, Michigan

263. Macneil C, Dick JTA, Elwood RW (1999) The dynamics of predation on Gammarus spp. (Crustacea: Amphipoda). Biol Rev 74(4):375-395

264. Liao C-M, Jou L-J, Chen B-C (2005) Risk-based approach to appraise valve closure in the clam Corbicula fluminea in response to waterborne metals. Environ Pollut 135(1):41-52. https://doi.org/10.1016/j.envpo 1.2004.10.015

265. Forrow DM, Maltby L (2000) Toward a mechanistic understanding of contaminant-induced changes in detritus processing in streams: Direct and indirect effects on detritivore feeding. Environ Toxicol Chem 19(8):2100-2106

266. Kelly DW, Dick JTA, Montgomery WI (2002) The functional role of Gammarus (Crustacea, Amphipoda): shredders, predators, or both? Hydrobiologia 485(1-3):199-203

267. Dangles O, Gessner MO, Guérold F, Chauvet E (2004) Impacts of stream acidification on litter breakdown: implications for assessing ecosystem functioning. J Appl Ecol 41 (2):365-378

268. Jonathan $F(1920)$ The larger fresh-water Crustacea of Canada. Ca Field Nat 34:126-132

269. Bousfield EL (1958) Fresh-water amphipod crustaceans of glaciated North America. Can Fld Nat 72:55-113

270. Mehennaoui Ket al (2016) Gammarus fossarum (Crustacea, Amphipoda) as a model organism to study the effects of silver nanoparticles. Sci Total Environ 566-567:1649-1659. https://doi.org/10.1016/j.scito tenv.2016.06.068

271. Borgmann U, Norwood WP (1997) Identification of the toxic agent in metal-contaminated sediments from Manitouwadge Lake, Ontario, using toxicity-accumulation relationships in Hyalella azteca. Can J Fish Aquat Sci 54(5):1055-1063. https://doi.org/10.1139/f97-021

272. De Cooman W, Blaise $C$, Janssen C, Detemmerman $L$, Elst R, Persoone G (2015) History and sensitivity comparison of two standard wholesediment toxicity tests with crustaceans: the amphipod Hyalella azteca and the ostracod Heterocypris incongruens microbiotest. Knowl Manag Aquat Ecosyst 416:15. https://doi.org/10.1051/kmae/2015011

273. Borgmann U (2002) Toxicity test methods and observations using the freshwater amphipod Hyalella, Environment Canada

274. Environment Canada (2013) Biological test method: test for survival and growth in sediment and water using the freshwater amphipod Hyalella azteca. Environ Prot Ser 1/RM/33
275. Sutcliffe DW, CarrickTR, Willoughby LG (1981) Effects of diet, body size, age and temperature on growth rates in the amphipod Gammarus pulex. Freshw Biol 11(2):183-214. https://doi. org/10.1111/j.1365-2427.1981.tb01252.x

276. Sutcliffe DW (1992) Reproduction in Gammarus (Crustacea, Amphipoda): basic processes. Freshw Forum 2(2):102-128

277. Crane M (1994) Population characteristics of Gammarus pulex (L.) from five English streams. Hydrobiologia 281(2):91-100. https://doi. org/10.1007/BF00006438

278. Mortensen E (1982) Production of Gammarus pulex L. (Amphipoda) in a small Danish stream. Hydrobiologia 87(1):77-97. https://doi. org/10.1007/BF00016664

279. Othman MS, Pascoe D (2001) Growth, development and reproduction of Hyalella azteca (Saussure, 1858) in laboratory culture. Crustaceana 74(2):171-181

280. Sprague JB (1963) Resistance of four freshwater crustaceans to lethal high temperature and low oxygen. J Fish Board Canada 20(2):387-415

281. Cussans M (1904) Gammarus. Liverpool Mar Biol Commitee Mem 12:1-47

282. Lincoln RJ (1979) British marine amphipoda: Gammaridea, vol. 818. British Museum (Natural History)

283. Graf F, Magniez A (1969) Surfaces respiratoires, aires cuticulaires perméables aux sels (nitrate d'argent et leuco-dérivés) et regions squelettiques non calcifiés chez quelques Crustacés Amphipodes. CR Acad Sci Paris 268:3191-3194

284. Sutcliffe DW (1978) Water chemistry and osmoregulation in some arthropods, especially Malacostraca. Annual Report, Freshwater Biological Association, Ambleside, pp 57-69

285. Morris RJ, Lockwood APM, Dawson ME (1982) An effect of acclimation salinity on the fatty acid composition of the gill phospholipids and water flux of the amphipod crustacean Gammarus duebeni. Comp Biochem Physiol Part A Physiol 72(3):497-503

286. Henry RP, Wheatly MG (1992) Interaction of respiration, ion regulation, and acid-base balance in the everyday life of aquatic crustaceans. Am Zool 32(3):407-416

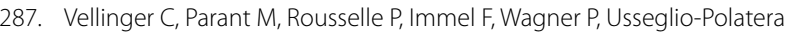
P (2012) Comparison of arsenate and cadmium toxicity in a freshwater amphipod (Gammarus pulex). Environ Pollut 160:66-73. https://doi. org/10.1016/J.ENVPOL.2011.09.002

288. Rainbow PS (1997) Ecophysiology of trace metal uptake in crustaceans. Estuar Coast Shelf Sci 44(2):169-176. https://doi.org/10.1006/ ecss.1996.0208

289. Felten V et al (2008) Physiological and behavioural responses of Gammarus pulex (Crustacea: Amphipoda) exposed to cadmium. Aquat Toxicol 86(3):413-425

290. Spicer Jl, Weber RE (1991) Respiratory impairment in crustaceans and molluscs due to exposure to heavy metals. Comp Biochem Physiol C 100(3):339-342

291. Lawrence AJ, Poulter C (1998) Development of a sub-lethal pollution bioassay using the estuarine amphipod Gammarus duebeni. Water Res 32(3):569-578

292. Xu Q (1995) The effects of exposure to zinc and cadmium separately and jointly on the free amino acid pool of Gammarus pulex (L.). Toxicol Environ Chem 50(1-4):183-196

293. Soegianto A, Charmantier-Daures M, Trilles J-P, Charmantier G (1999) Impact of cadmium on the structure of gills and epipodites of the shrimp Penaeus japonicas (Crustacea: Decapoda). Aquat Living Resour 12(1):57-70

294. Silvestre F, Trausch G, Devos P (2005) Hyper-osmoregulatory capacity of the Chinese mitten crab (Eriocheir sinensis) exposed to cadmium; acclimation during chronic exposure. Comp Biochem Physiol Part C Toxicol Pharmacol 140(1):29-37

295. Geffard A, Sartelet H, Garric J, Biagianti-Risbourg S, Delahaut L, Geffard O (2010) Subcellular compartmentalization of cadmium, nickel, and lead in Gammarus fossarum: Comparison of methods. Chemosphere 78(7):822-829. https://doi.org/10.1016/J.CHEMOSPHERE.2009.11.051

296. Koropatnick J (2010) Metallothionein and Metal Homeostasis. In: Zalups RK, Koropatnick J (eds) Cellular and molecular biology of metals. CRC Press, London, pp 143-180

297. Ahearn GA (2010) Heavy metal transport and detoxification in crustacean gastrointestinal and renal epithelial cells. In: Zalups RK, 
Koropatnick J (eds) Cellular and molecular biology of metals. CRC Press, London, pp 295-326

298. Lebrun JD, Perret M, Uher E, Tusseau-Vuillemin M-H, Gourlay-Francé C (2011) Waterborne nickel bioaccumulation in Gammarus pulex: Comparison of mechanistic models and influence of water cationic composition. Aquat Toxicol 104(3-4):161-167. https://doi.org/10.1016/J.AQUAT OX.2011.04.011

299. Watkins JM, Dermott R, Lozano SJ, Mills EL, Rudstam LG, Scharold JV (2007) Evidence for remote effects of Dreissenid mussels on the amphipod Diporeia. Analysis of Lake Ontario benthic surveys, 1972-2003. J Great Lakes Res 33(3):642-657. https://doi.org/10.3394/03801330(2007)33[642:EFREOD]2.0.CO;2

300. Watkins JM, Rudstam LG, Mills EL, Teece MA (2012) Coexistence of the native benthic amphipod Diporeia spp. and exotic dreissenid mussels in the New York Finger Lakes. J Great Lakes Res 38(2):226-235. https://doi. org/10.1016/J.JGLR.2012.02.001

301. ASTM International,"ASTM E1706-05(2010), Standard test method for measuring the toxicity of sediment-associated contaminants with freshwater invertebrates, ASTM International, West Conshohocken, PA, 2010, www.astm.org," 2010. https://www.astm.org/Standards/E1706 .htm (accessed Feb. 21, 2018).

302. Bundschuh M, Zubrod JP, Englert D, Seitz F, Rosenfeldt RR, Schulz R (2011) Effects of nano-TiO in combination with ambient UV-irradiation on a leaf shredding amphipod. Chemosphere 85(10):1563-1567. https ://doi.org/10.1016/j.chemosphere.2011.07.060

303. Garaud M et al (2015) Multibiomarker assessment of cerium dioxide nanoparticle $\left(\mathrm{nCeO}_{2}\right)$ sublethal effects on two freshwater invertebrates, Dreissena polymorpha and Gammarus roeseli. Aquat Toxicol 158:63-74. https://doi.org/10.1016/j.aquatox.2014.11.004

304. Mehennaoui K et al (2018) Do the pristine physico-chemical properties of silver and gold nanoparticles influence uptake and molecular effects on Gammarus fossarum (Crustacea Amphipoda)? Sci Total Environ 643:1200-1215. https://doi.org/10.1016/J.SCITOTENV.2018.06.208

305. Lüderwald $\mathrm{S}$ et al (2019) Exposure pathway dependent effects of titanium dioxide and silver nanoparticles on the benthic amphipod Gammarus fossarum. Aquat Toxicol 212:47-53. https://doi.org/10.1016/j. aquatox.2019.04.016

306. McCahon CP, Pascoe D (1988) Use of Gammarus pulex (L.) in safety evaluation tests: Culture and selection of a sensitive life stage. Ecotoxicol Environ Saf 15(3):245-252. https://doi.org/10.1016/0147-6513(88)90078 $-4$

307. Ashauer R, Hintermeister A, Caravatti I, Kretschmann A, Escher BI (2010) Toxicokinetic and toxicodynamic modeling explains carry-over toxicity from exposure to diazinon by slow organism recovery. Environ Sci Technol 44(10):3963-3971. https://doi.org/10.1021/es903478b

308. Lebrun JD, Perret M, Geffard A, Gourlay-Francé C (2012) Modelling copper bioaccumulation in Gammarus pulex and alterations of digestive metabolism. Ecotoxicology 21(7):2022-2030. https://doi.org/10.1007/ s10646-012-0955-7

309. Jeon J, Kurth D, Ashauer R, Hollender J (2013) Comparative toxicokinetics of organic micropollutants in freshwater crustaceans. Environ Sci Technol 47(15): 8809-8817. https://doi.org/10.1021/es400833g

310. Lebrun JD, Leroy D, Giusti A, Gourlay-Francé C, Thomé J-P (2014) Bioaccumulation of polybrominated diphenyl ethers (PBDEs) in Gammarus pulex: Relative importance of different exposure routes and multipathway modeling. Aquat Toxicol 154:107-113. https://doi.org/10.1016/J. AQUATOX.2014.05.015

311. Kühr S, Schneider S, Meisterjahn B, Schlich K, Hund-Rinke K, Schlechtriem C (2018) Silver nanoparticles in sewage treatment plant effluents: chronic effects and accumulation of silver in the freshwater amphipod Hyalella azteca. Environ Sci Eur 30(1):7. https://doi.org/10.1186/s1230 2-018-0137-1

312. Poynton HC, Chen C, Alexander SL, Major KM, Blalock BJ, Unrine JM (2019) Enhanced toxicity of environmentally transformed ZnO nanoparticles relative to $\mathrm{Zn}$ ions in the epibenthic amphipod Hyalella azteca. Environ Sci Nano. https://doi.org/10.1039/C8EN00755A

313. Schlechtriem C et al (2019) Bioconcentration studies with the freshwater amphipod Hyalella azteca: are the results predictive of bioconcentration in fish? Environ Sci Pollut Res 26(2):1628-1641. https://doi. org/10.1007/s11356-018-3677-4
314. Kuehr S, Klehm J, Stehr C, Menzel M, Schlechtriem C (2020) Unravelling the uptake pathway and accumulation of silver from manufactured silver nanoparticles in the freshwater amphipod Hyalella azteca using correlative microscopy. Nanolmpact 19:100239. https://doi.org/10.1016/j. impact.2020.100239

315. Kuehr S, Kaegi R, Maletzki D, Schlechtriem C (2020) Testing the bioaccumulation potential of manufactured nanomaterials in the freshwater amphipod Hyalella azteca. Chemosphere 263:127961. https://doi. org/10.1016/..chemosphere.2020.127961

316. Uznanski RL, Nickol BB (1980) Parasite population regulation: Lethal and sublethal effects of Leptorhynchoides thecatus (Acanthocephala: Rhadinorhynchidae) on Hyalella azteca (Amphipoda). J Parasitol 66(1):121-126

317. Muzzall PM (1982) Parasites of Gammarus pseudolimnaeus and Hyalella azteca. Proc Helminthol Soc Wash 49(2):289-294

318. Pascoe D, Kedwards TJ, Blockwell SJ, Taylor EJ (1995) Gammarus pulex (L.) feeding bioassay - effects of parasitism. Bull Environ Contam Toxicol 55(4):629-632

319. Bakker TCM, Mazzi D, Zala S (1997) Parasite-induced changes in behavior and color make Gammarus pulex more prone to fish predation. Ecology 78(4):1098-1104

320. Rauque CA, Semenas L (2009) Effects of two acanthocephalan species on the reproduction of Hyalella patagonica (Amphipoda, Hyalellidae) in an Andean Patagonian Lake (Argentina). J Invertebr Pathol 100(1):35-39

321. Duclos LM, Danner BJ, Nickol BB (2006) Virulence of Corynosoma constrictum (Acanthocephala: Polymorphidae) in Hyalella azteca (Amphipoda) throughout parasite ontogeny. J Parasitol 92(4):749-755

322. Gismondi E, Cossu-Leguille C, Beisel J-N (2012) Acanthocephalan parasites: help or burden in gammarid amphipods exposed to cadmium? Ecotoxicology 21(4):1188-1193

323. Gismondi E, Beisel J-N, Cossu-Leguille C (2012) Influence of gender and season on reduced glutathione concentration and energy reserves of Gammarus roeseli. Environ Res 118:47-52

324. Gismondi E, Rigaud T, Beisel J-N, Cossu-Leguille C (2012) Microsporidia parasites disrupt the responses to cadmium exposure in a gammarid. Environ Pollut 160:17-23

325. Frank SN, Godehardt S, Nachev M, Trubiroha A, Kloas W, Sures B (2013) Influence of the cestode Ligula intestinalis and the acanthocephalan Polymorphus minutus on levels of heat shock proteins (HSP70) and metallothioneins in their fish and crustacean intermediate hosts. Environ Pollut 180:173-179

326. Marijić VF, Smrzlić IV, Raspor B (2013) Effect of acanthocephalan infection on metal, total protein and metallothionein concentrations in European chub from a Sava River section with low metal contamination. Sci Total Environ 463:772-780

327. Bunke M, Alexander ME, Dick JTA, Hatcher MJ, Paterson R, Dunn AM (2015) Eaten alive: cannibalism is enhanced by parasites. R Soc Open Sci 2(3):140369-140369. https://doi.org/10.1098/rsos.140369

328. Sutcliffe DW (1993) Reproduction in Gammarus (Crustacea, Amphipoda): female strategies. Freshw Forum 3:26-64

329. Bloor M (2010) Animal standardisation for mixed species ecotoxicological studies: Establishing a laboratory breeding programme for Gammarus pulex and Asellus aquaticus. Zool Baetica 21:179-190

330. Kunz PY, Kienle C, Gerhardt A (2010) Gammarus spp. in aquatic ecotoxicology and water quality assessment: toward integrated multilevel tests. Rev Environ Contam Toxicol 205:1-76. https://doi. org/10.1007/978-1-4419-5623-1

331. McGrath KE, Peeters ETHM, Beijer JAJ, Scheffer M (2007) Habitatmediated cannibalism and microhabitat restriction in the stream invertebrate Gammarus pulex. Hydrobiologia 589(1):155-164. https:// doi.org/10.1007/s10750-007-0731-5

332. de March BGE (1977) The effects of photoperiod and temperature on the induction and termination of reproductive resting stage in the freshwater amphipod Hyalella azteca (Saussure). Can J Zool 55(10):1595-1600. https://doi.org/10.1139/z77-208

333. de March BGE (1978) The effects of constant and variable temperatures on the size, growth, and reproduction of the freshwater amphipod Hyalella azteca (Saussure). Can J Zool 56(8):1801-1806. https://doi. org/10.1139/z78-246

334. Borgmann U, Ralph KM, Norwood WP (1989) Toxicity test procedures for Hyalella azteca, and chronic toxicity of cadmium and 
pentachlorophenol to H. azteca, Gammarus fasciatus, and Daphnia magna. Arch Environ Contam Toxicol 18(5):756-764

335. Raths J, Kuehr S, Schlechtriem C (2020) Bioconcentration, metabolism, and spatial distribution of $14 \mathrm{C}$-labeled laurate in the freshwater amphipod Hyalella azteca. Environ Toxicol Chem 39(2):310-322. https://doi. org/10.1002/etc.4623

336. Borgmann U (1996) Systematic analysis of aqueous ion requirements of Hyalella azteca: a standard artificial medium including the essential bromide ion. Arch Environ Contam Toxicol 30(3):356-363. https://doi. org/10.1007/BF00212294

337. Golding LA, Borgmann U, George-Dixon D (2013) Cadmium bioavailability to Hyalella azteca from a periphyton diet compared to an artificial diet and application of a biokinetic model. Aquat Toxicol 126:291-298. https://doi.org/10.1016/J.AQUATOX.2012.09.016

338. Wilder J (1940) The effects of population density upon growth reproduction, and survival of Hyalella azteca. Physiol Zool 13(4):439-461

339. Gardner WS, Landrum PF, Cavaletto JF (1990) Lipid-partitioning and disposition of benzo[a]pyrene and hexachlorobiphenyl in Lake Michigan Pontoporeia hoyi and Mysis relicta. Environ Toxicol Chem 9(10):12691278. https://doi.org/10.1002/etc.5620091005

340. Ashauer R, Boxall A, Brown C (2006) Uptake and elimination of chlorpyrifos and pentachlorophenol into the freshwater amphipod Gammarus pulex. Arch Environ Contam Toxicol 51(4):542-548. https://doi. org/10.1007/s00244-005-0317-z

341. Gross-Sorokin MY, Grist EPM, Cooke M, Crane M (2003) Uptake and depuration of 4-nonylphenol by the benthic invertebrate Gammarus pulex: how important is feeding rate? Environ Sci Technol 37(10):223641.doi: 10.1021/es020092n

342. Urien N, Uher E, Billoir E, Geffard O, Fechner LC, Lebrun JD (2015) A biodynamic model predicting waterborne lead bioaccumulation in Gammarus pulex: Influence of water chemistry and in situ validation. Environ Pollut 203:22-30. https://doi.org/10.1016/J.ENVPOL.2015.03.045

343. Xu Q, Pascoe D (1993) The bioconcentration of zinc by Gammarus pulex (L.) and the application of a kinetic model to determine bioconcentration factors. Water Res 27(11):1683-1688. https://doi.org/10.1016/00431354(93)90132-2

344. Spehar RL, Anderson RL, Fiandt JT (1978) Toxicity and bioaccumulation of cadmium and lead in aquatic invertebrates. Environ Pollut 15(3):195-208. https://doi.org/10.1016/0013-9327(78)90065-4

345. Alves LC, Borgmann U, Dixon DG (2008) Water-sediment interactions for Hyalella azteca exposed to uranium-spiked sediment. Aquat Toxicol 87(3):187-199. https://doi.org/10.1016/J.AQUATOX.2008.01.016

346. Borgmann U (1998) A mechanistic model of copper accumulation in Hyalella azteca. Sci Total Environ 219(2-3):137-145. https://doi. org/10.1016/S0048-9697(98)00229-0

347. Clason B, Gulliksen B, Zauke G-P (2004) Assessment of two-compartment models as predictive tools for the bioaccumulation of trace metals in the amphipod Gammarus oceanicus Segerstråle, 1947 from Grunnfjord (Northern Norway). Sci Total Environ 323(1-3):227-241. https://doi.org/10.1016/J.SCITOTENV.2003.09.035

348. Fu Q et al (2020) Biotransformation Changes Bioaccumulation and Toxicity of Diclofenac in Aquatic Organisms. Environ Sci Technol 54(7):4400-4408. https://doi.org/10.1021/acs.est.9b07127

349. Kosfeld $V$ et al (2020) Comparison of alternative methods for bioaccumulation assessment: scope and limitations of in vitro depletion assays with rainbow trout and bioconcentration tests in the freshwater amphipod Hyalella azteca. Environ Toxicol Chem 39(9):1813-1825. https ://doi.org/10.1002/etc.4791

350. Kampfraath AA et al (2012) DECOTAB: a multipurpose standard substrate to assess effects of litter quality on microbial decomposition and invertebrate consumption. Freshw Sci 31(4):1156-1162. https:// doi.org/10.1899/12-075.1

351. Borgmann U, Nonvood WP, Clarke C (1993) Accumulation, regulation and toxicity of copper, zinc, lead and mercury in Hyalella azteca. Hydrobiologia 259:79-89.

352. Borgmann U, Norwood WP. Dixon DG (2004) Re-evaluation of metal bioaccumulation and chronic toxicity in Hyalella azteca using saturation curves and the biotic ligand model. Environ Pollut 131(3):469484. https://doi.org/10.1016/J.ENVPOL.2004.02.010

353. Norwood WP, Borgmann U, Dixon DG (2006) Saturation models of arsenic, cobalt, chromium and manganese bioaccumulation by Hyalella azteca. Environ Pollut 143(3):519-528. https://doi. org/10.1016/J.ENVPOL.2005.11.041

354. Paquin PR et al (2002) The biotic ligand model: a historical overview. Comp Biochem Physiol Part C Toxicol Pharmacol 133(1-2):3-35. https ://doi.org/10.1016/S1532-0456(02)00112-6

355. Shuhaimi-Othman M, Abas A, Yap SS, Maziati M (2006) Bioaccumulation and elimination of copper and lead by freshwater prawn Macrobrachium lanchesteri. J Biol Sci 6(4):717-722

356. Shuhaimi-Othman M, Pascoe D (2007) Bioconcentration and depuration of copper, cadmium, and zinc mixtures by the freshwater amphipod Hyalella azteca. Ecotoxicol Environ Saf 66(1):29-35. https:// doi.org/10.1016/J.ECOENV.2006.03.003

357. Forró L, Korovchinsky NM, Kotov AA, Petrusek A (2008) Global diversity of cladocerans (Cladocera; Crustacea) in freshwater. Hydrobiologia 595(1):177-184. https://doi.org/10.1007/s10750-007-9013-5

358. Ebert D (2005) Introduction to Daphnia Biology. In: Ecology, Epidemiology, and Parasitism in Daphnia. National Center for Biotechnology Information (US), Bethesda (MD), pp 1-25

359. Storch V, Welsch U (2014) Kükenthal-Zoologisches Praktikum. Springer-Verlag, New York

360. Hebert PDN (1978) The population bilogy of Daphnia (Crustacea, Daphnidae). Biol Rev 53(3):387-426. https://doi.org/10.1111/j.1469185X.1978.tb00860.x

361. Stollewerk A (2010) The water flea Daphnia-a'new' model system for ecology and evolution? J Biol 9(2):21. https://doi.org/10.1186/jbiol 212

362. Lampert W (1987) Feeding and nutrition in Daphnia. Mem Ist ital Idrobiol 45:143-192

363. Shaw JR, et al. Daphnia as an emerging model for toxicological genomics. In: Advances in Experimental Biology, vol. 2, C. Hogstrand and P. Kille, Eds. Elsevier, 2008, pp. 165-328

364. Thorp JH, Covich AP (2001) An overview of freshwater habitats, 2nd Edn. Academic Press, San Diego

365. Geller W, Müller H (1981) The filtration apparatus of Cladocera: filter mesh-sizes and their implications on food selectivity. Oecologia 49(3):316-321

366. Rubenstein DI, Koehl MAR (1977) The mechanisms of filter feeding: some theoretical considerations. Am Nat 111(981):981-994

367. Koehl MAR (1996) When does morphology matter? Annu Rev Ecol Syst 27(1):501-542

368. Gerritsen J, Porter KG, Strickler JR (1988) Not by sieving alone: observations of suspension feeding in Daphnia. Bull Mar Sci 43(3):366-376

369. Bednarska A (2006) Adaptive changes in morphology of Daphnia filter appendages in response to food stress. Polish J Ecol 54(4):663-668

370. Smirnov NN (2017) Physiology of the Cladocera. Academic Press, Second edn

371. MetschnikoffE (1884) Ueber eine Sprosspilzkrankheit der Daphnien. Beitrag zur Lehre über den Kampf der Phagocyten gegen Krankheitserreger. Arch für Pathol Anat und Physiol und für Klin Med 96(2):177-195. https://doi.org/10.1007/BF02361555

372. Bianchini A, Wood CM (2003) Mechanism of acute silver toxicity in Daphnia magna. Environ Toxicol Chem 22(6):1361-1367

373. Guan R, Wang W-X (2004) Cd and Zn uptake kinetics in Daphnia magna in relation to $\mathrm{Cd}$ exposure history. Environ Sci Technol 38(22):6051-6058

374. Tsui MTK, Wang W (2005) Influences of maternal exposure on the tolerance and physiological performance of Daphnia magna under mercury stress. Environ Toxicol Chem 24(5):1228-1234

375. Fraysse B, Geffard O, Berthet B, Quéau H, Biagianti-Risbourg S, Geffard A (2006) Importance of metallothioneins in the cadmium detoxification process in Daphnia magna. Comp Biochem Physiol C Toxicol Pharmacol 144(3):286-293. https://doi.org/10.1016/j.cbpc.2006.10.003

376. Wu F, Bortvedt A, Harper BJ, Crandon LE, Harper SL (2017) Uptake and toxicity of $\mathrm{CuO}$ nanoparticles to Daphnia magna varies between indirect dietary and direct waterborne exposures. Aquat Toxicol 190:78-86. https://doi.org/10.1016/j.aquatox.2017.06.021

377. OECD (2004) Test No. 202: Daphnia sp. Acute Immobilisation Test. OECD

378. OECD (2012) Test No. 211: Daphnia magna Reproduction Test. OECD. https://doi.org/10.1787/9789264185203-en 
379. Southworth $\mathrm{G}$ (1978) Bioaccumulation potential of polycyclic aromatic hydrocarbons in Daphnia pulex. Water Res 12(11):973-977. https://doi. org/10.1016/0043-1354(78)90080-5

380. Herbes SE, Risi GF (1978) Metabolic alteration and excretion of anthracene by Daphnia pulex. Bull Environ Contam Toxicol 19(1):147-155. https://doi.org/10.1007/bf01685780

381. Elendt B-P (1990) Selenium deficiency in Crustacea. Protoplasma 154(1):25-33. https://doi.org/10.1007/BF01349532

382. Crosby DG, Tucker RK (1971) Accumulation of DDT by Daphnia magna. Environ Sci Technol 5(8):714-716. https://doi.org/10.1021/es60055a003

383. Canton J, Greve P, Slooff W, Vanesch G (1975) Toxicity, accumulation and elimination studies of a-hexachlorocyclohexane $(\mathrm{a}-\mathrm{HCH})$ with freshwater organisms of different trophic levels. Water Res 9(12):1163-1169. https://doi.org/10.1016/0043-1354(75)90116-5

384. ASTM International (2014) ASTM E729-96(2014) Standard guide for conducting acute toxicity tests on test materials with fishes, macroinvertebrates, and amphibians. West Conshohocken, PA. https://doi. org/10.1520/E0729-96R14

385. Nebeker AV (1976) Survival of daphnia, crayfish, and stoneflies in airsupersaturated Water. J Fish Res Board Canada 33(5):1208-1212. https:// doi.org/10.1139/f76-156

386. Skjolding LM, Winther-Nielsen M, Baun A (2014) Trophic transfer of differently functionalized zinc oxide nanoparticles from crustaceans (Daphnia magna) to zebrafish (Danio rerio). Aquat Toxicol 157:101-108. https://doi.org/10.1016/j.aquatox.2014.10.005

387. Skjolding LM et al (2014) Uptake and depuration of gold nanoparticles in Daphnia magna. Ecotoxicology 23(7):1172-1183. https://doi. org/10.1007/s10646-014-1259-x

388. Hu J, Wang D, Wang J, Wang J (2012) Bioaccumulation of $\mathrm{Fe}_{2} \mathrm{O}_{3}$ (magnetic) nanoparticles in Ceriodaphnia dubia. Environ Pollut 162:216-222. https://doi.org/10.1016/j.envpol.2011.11.016

389. Chen X, Zhu Y, Yang K, Zhu L, Lin D (2019) Nanoparticle $\mathrm{TiO}_{2}$ size and rutile content impact bioconcentration and biomagnification from algae to daphnia. Environ Pollut 247:421-430. https://doi.org/10.1016/j. envpol.2019.01.022

390. Tan L-Y, Huang B, Xu S, Wei Z-B, Yang L-Y, Miao A-J (2016) TiO 2 nanoparticle uptake by the water flea Daphnia magna via different routes is calcium-dependent. Environ Sci Technol 50(14):7799-7807

391. Li WM, Wang WX (2013) Distinct biokinetic behavior of ZnO nanoparticles in Daphnia magna quantified by synthesizing ${ }^{65} \mathrm{Zn}$ tracer. Water Res 47(2):895-902. https://doi.org/10.1016/j.watres.2012.11.018

392. Tan C, Wang WX (2014) Modification of metal bioaccumulation and toxicity in Daphnia magna by titanium dioxide nanoparticles. Environ Pollut 186:36-42. https://doi.org/10.1016/j.envpol.2013.11.015

393. Lewinski NA et al (2010) Quantification of water solubilized CdSe/ZnS quantum dots in Daphnia magna. Environ Sci Technol 44(5):1841-1846. https://doi.org/10.1021/es902728a

394. Fan W, Liu L, Peng R, Wang WX (2016) High bioconcentration of titanium dioxide nanoparticles in Daphnia magna determined by kinetic approach. Sci Total Environ 569-570:1224-1231. https://doi. org/10.1016/j.scitotenv.2016.06.197

395. ASTM (2012) ASTM E1193/1997 (2012) Daphnia magna (Acute Toxicity Test). West Conshohocken, PA https://doi.org/101520/E1193-97R12

396. Maciorowski HD, Kondra PM (1975) Flow-through apparatus for acute toxicity bioassays with aquatic invertebrates. Technical Report Series No. CEN/T-75-2. Department of the Environment. Fisheries and Marine Service. Fisheries Operations Directorate Central Region. Winnipeg, Canada

397. Maki AW (1977) Modifications of continuous-flow toxicity test methods for small aquatic organisms. Progress Fish-Culturist 39(4):172-174. https ://doi.org/10.1577/1548-8659(1977)39[172:MOCTTM]2.0.CO;2

398. Zumwalt DC, Dwyer FJ, Greer IE, Ingersoll CG (1994) A water-renewal system that accurately delivers small volumes of water to exposure chambers. Environ Toxicol Chem 13(8):1311-1314. https://doi. org/10.1002/etc.5620130813

399. Biesinger KE, Anderson LE, Eaton JG (1982) Chronic effects of inorganic and organic mercury on Daphnia magna: Toxicity, accumulation, and loss. Arch Environ Contam Toxicol 11(6):769-774. https://doi. org/10.1007/BF01059166

400. Meinertz JR, Greseth SL, Gaikowski MP, Schmidt LJ (2008) Chronic toxicity of hydrogen peroxide to Daphnia magna in a continuous exposure, flow-through test system. Sci Total Env 392(2-3):225-232. https://doi. org/10.1016/j.scitotenv.2007.12.015

401. Kim HY, Jeon J, Hollender J, Yu S, Kim SD (2014) Aqueous and dietary bioaccumulation of antibiotic tetracycline in D. magna and its multigenerational transfer. J Hazard Mater 279:428-435. https://doi. org/10.1016/j.jhazmat.2014.07.031

402. McCarthy JF (1983) Role of participate organic matter in decreasing accumulation of polynuclear aromatic hydrocarbons by Daphnia magna. Arch Env Contam Toxicol 12(5):559-568. https://doi. org/10.1007/BF01056552

403. Lee WM, Yoon SJ, Shin YJ, An YJ (2015) Trophic transfer of gold nanoparticles from Euglena gracilis or Chlamydomonas reinhardtii to Daphnia magna. Environ Pollut 201:10-16. https://doi.org/10.1016/j.envpo I.2015.02.021

404. Kwon D, Nho HW, Yoon TH (2015) Transmission electron microscopy and scanning transmission $\mathrm{X}$-ray microscopy studies on the bioaccumulation and tissue level absorption of $\mathrm{TiO}_{2}$ nanoparticles in Daphnia magna. J Nanosci Nanotechnol 15(6):4229-4238. https://doi. org/10.1166/jnn.2015.9695

405. Lee BT, Kim HA, Williamson JL, Ranville JF (2016) Bioaccumulation and in-vivo dissolution of CdSe/ZnS with three different surface coatings by Daphnia magna. Chemosphere 143:115-122. https://doi.org/10.1016/j. chemosphere.2015.06.049

406. Jensen LHS et al (2017) Not all that glitters is gold - Electron microscopy study on uptake of gold nanoparticles in Daphnia magna and related artifacts. Environ Toxicol Chem 36(6):1503-1509. https://doi. org/10.1002/etc.3697

407. Lovern SB, Owen HA, Klaper R (2008) Electron microscopy of gold nanoparticle intake in the gut of Daphnia magna. Nanotoxicology 2(1):43-48. https://doi.org/10.1080/17435390801935960

408. Xiao Y, Vijver MG, Chen G, Peijnenburg WJGM (2015) Toxicity and accumulation of Cu and ZnO nanoparticles in Daphnia magna. Environ Sci Technol 49(7):4657-4664. https://doi.org/10.1021/acs.est.5b00538

409. Kim I, Lee B-T, Kim H-A, Kim K-W, Kim SD, Hwang Y-S (2016) Citrate coated silver nanoparticles change heavy metal toxicities and bioaccumulation of Daphnia magna. Chemosphere 143:99-105. https://doi. org/10.1016/J.CHEMOSPHERE.2015.06.046

410. Ribeiro F, Van Gestel CA, Pavlaki MD, Azevedo S, Soares AM, Loureiro S (2017) Bioaccumulation of silver in Daphnia magna: Waterborne and dietary exposure to nanoparticles and dissolved silver. Sci Total Env 574:1633-1639. https://doi.org/10.1016/j.scitotenv.2016.08.204

411. Krystek P, Brandsma S, Leonards P, De Boer J (2016) Exploring methods for compositional and particle size analysis of noble metal nanoparticles in Daphnia magna. Talanta 147:289-295. https://doi.org/10.1016/j. talanta.2015.09.063

412. Zhu X, Chang Y, Chen Y (2010) Toxicity and bioaccumulation of $\mathrm{TiO}^{2}$ nanoparticle aggregates in Daphnia magna. Chemosphere 78(3):209_ 215. https://doi.org/10.1016/j.chemosphere.2009.11.013

413. Dalai S, Iswarya V, Bhuvaneshwari M, Pakrashi S, Chandrasekaran N, Mukherjee A (2014) Different modes of $\mathrm{TiO}_{2}$ uptake by Ceriodaphnia dubia: Relevance to toxicity and bioaccumulation. Aquat Toxicol 152:139-146. https://doi.org/10.1016/j.aquatox.2014.04.002

414. Khan FR et al (2014) In vivo retention of ingested au NPs by Daphnia magna: No evidence for trans-epithelial alimentary uptake. Chemosphere 100:97-104. https://doi.org/10.1016/j.chemosphere.2013.12.051

415. Harush-Frenkel O, Debotton N, Benita S, Altschuler Y (2007) Targeting of nanoparticles to the clathrin-mediated endocytic pathway. Biochem Biophys Res Commun 353(1):26-32

416. García-Alonso J et al (2011) Cellular internalization of silver nanoparticles in gut epithelia of the estuarine polychaete Nereis diversicolor. Environ Sci Technol 45(10):4630-4636

417. Jackson BP, Pace HE, Lanzirotti A, Smith R, Ranville JF (2009) Synchrotron $X$-ray 2D and 3D elemental imaging of CdSe/ZnS quantum dot nanoparticles in Daphnia magna. Anal Bioanal Chem 394(3):911-917. https ://doi.org/10.1007/s00216-009-2768-y

418. Heinlaan M, Kahru A, Kasemets K, Arbeille B, Prensier G, Dubourquier $\mathrm{H}-\mathrm{C}$ (2011) Changes in the Daphnia magna midgut upon ingestion of copper oxide nanoparticles: a transmission electron microscopy study. Water Res 45(1):179-190 
419. Derjaguin BV, Churaev NV, Muller VM (1987) The Derjaguin—LandauVerwey-Overbeek (DLVO) theory of stability of lyophobic colloids. In: Surface Forces. Springer, New York, pp 293-310

420. Handy RD, von der Kammer F, Lead JR, Hassellöv M, Owen R, Crane M (2008) The ecotoxicology and chemistry of manufactured nanoparticles. Ecotoxicology 17(4):287-314. https://doi.org/10.1007/s1064 6-008-0199-8

421. Moëzzi F, Hedayati SA, Ghadermarzi A (2019) Copper bioaccumulation kinetics in swan mussel, Anodonta cygnea (Linnaeus, 1758) during waterborne exposure to $\mathrm{CuO}$ nanoparticles. Bull Environ Contam Toxicol 102(1):46-51

422. Koehle-Divo V et al (2019) A sub-individual multilevel approach for an integrative assessment of CuO nanoparticle effects on Corbicula fluminea. Environ Pollut 254:112976. https://doi.org/10.1016/j.envpo I.2019.112976

423. Fan X, Wang C, Wang $\mathrm{P}, \mathrm{Hu}$ B, Wang X (2018) $\mathrm{TiO}_{2}$ nanoparticles in sediments: Effect on the bioavailability of heavy metals in the freshwater bivalve Corbicula fluminea. J Hazard Mater 342:41-50. https://doi. org/10.1016/j.jhazmat.2017.07.041

424. Garaud M et al (2016) Integrated assessment of ceria nanoparticle impacts on the freshwater bivalve Dreissena polymorpha. Nanotoxicology 10(7):935-944. https://doi.org/10.3109/17435390.2016.1146363

425. Zimmermann S, Ruchter N, Loza K, Epple M, Sures B (2017) Nanoparticulate versus ionic silver: Behavior in the tank water, bioaccumulation, elimination and subcellular distribution in the freshwater mussel Dreissena polymorpha. Environ Pollut 222:251-260. https://doi.org/10.1016/j. envpol.2016.12.048

426. Misra SK et al (2012) Isotopically modified nanoparticles for enhanced detection in bioaccumulation studies. Environ Sci Technol 46(2):12161222. https://doi.org/10.1021/es2039757

427. Croteau MN, Misra SK, Luoma SN, Valsami-Jones E (2014) Bioaccumulation and toxicity of $\mathrm{CUO}$ nanoparticles by a freshwater invertebrate after waterborne and dietborne exposures. Environ Sci Technol 48(18):10929-10937. https://doi.org/10.1021/es5018703

428. Oliver AL-S et al (2014) Does water chemistry affect the dietary uptake and toxicity of silver nanoparticles by the freshwater snail Lymnaea stagnalis? Environ Pollut 189:87-91. https://doi.org/10.1016/J.ENVPO L.2014.02.010

429. Luoma SN, Stoiber T, Croteau MN, Römer I, Merrifeld R, Lead JR (2016) Effect of cysteine and humic acids on bioavailability of $\mathrm{Ag}$ from $\mathrm{Ag}$ nanoparticles to a freshwater snail. Nanolmpact 2:61-69. https://doi. org/10.1016/j.impact.2016.06.006
430. Ramskov T, Forbes VE Gilliland D, Selck H (2015) Accumulation and effects of sediment-associated silver nanoparticles to sediment-dwelling invertebrates. Aquat Toxicol 166:96-105. https://doi.org/10.1016/j. aquatox.2015.07.002

431. Ramskov T, Croteau MN, Forbes VE, Selck H (2015) Biokinetics of different-shaped copper oxide nanoparticles in the freshwater gastropod, Potamopyrgus antipodarum. Aquat Toxicol 163:71-80. https://doi. org/10.1016/j.aquatox.2015.03.020

432. Pang C et al (2012) Effects of sediment-associated copper to the deposit-feeding snail, Potamopyrgus antipodarum: A comparison of Cu added in aqueous form or as nano- and micro-CuO particles. Aquat Toxicol 106-107:114-122. https://doi.org/10.1016/j.aquat ox.2011.10.005

433. Pang $C$ et al (2013) Bioaccumulation, toxicokinetics, and effects of copper from sediment spiked with aqueous $\mathrm{Cu}$, nano-CuO, or micro-CuO in the deposit-feeding snail, Potamopyrgus antipodarum. Environ Toxico Chem. https://doi.org/10.1002/etc.2216

434. Ma T, Wang M, Gong S, Tian B (2017) Impacts of sediment organic matter content and $\mathrm{pH}$ on ecotoxicity of coexposure of $\mathrm{TiO}_{2}$ nanoparticles and cadmium to freshwater snails Bellamya aeruginosa. Arch Environ Contam Toxicol 72(1):153-165

435. Burkal JZ, Gregersen NF, Reventlow JT, Syberg K (2015) Long-term Effects of CuO Nanoparticles on Hyalella azteca. Roskilde University

436. Santos-Rasera JR, SantAnnaNeto RT, RosimMonteiro CAM et al (2019) Toxicity, bioaccumulation and biotransformation of Cu oxide nanoparticles in Daphnia magna. Environ Sci Nano 6(9):2897-2906. https://doi. org/10.1039/c9en00280d

437. Kalman J, Paul KB, Khan FR, Stone V, Fernandes TF (2015) Characterisation of bioaccumulation dynamics of three differently coated silver nanoparticles and aqueous silver in a simple freshwater food chain. Environ Chem 12(6):662. https://doi.org/10.1071/EN15035

438. Zhao CM, Wang WX (2010) Biokinetic uptake and efflux of silver nanoparticles in Daphnia magna. Environ Sci Technol 44(19):7699-7704. https://doi.org/10.1021/es101484s

\section{Publisher's Note}

Springer Nature remains neutral with regard to jurisdictional claims in published maps and institutional affiliations.

\section{Submit your manuscript to a SpringerOpen ${ }^{\circ}$ journal and benefit from:}

- Convenient online submission

- Rigorous peer review

- Open access: articles freely available online

- High visibility within the field

- Retaining the copyright to your article

Submit your next manuscript at $\boldsymbol{\nabla}$ springeropen.com 